ILLINOIS

NATURAL

HISTORY

S UR VEY

\section{MAY 101994}

\section{LIERARY}

\title{
Systematics of Leptosphaeria Species Found on the Rosaceae
}

Sabine M. Huhndorf

\author{
Illinois Natural History Survey Bulletin \\ Volume 34, Article 5 \\ May 1992
}

UEPOSITORYY 

I LLINOIS

NATURAL

HISTORY

S UR VEY

\section{Systematics of Leptosphaeria Species Found on the Rosaceae}

Sabine M. Huhndorf

Illinois Natural History Survey

Illinois Natural History Survey Bulletin

Volume 34, Article 5

May 1992 
Illinois Natural History Survey, Lorin I. Nevling, Chief

A Division of the lllinois Department of Energy and Natural Resources

A catalog of the publications of the Illinois Natural History Survey is available without charge from the address below. A price list and an order blank are included with the catalog.

Illinois Natural History Survey

Distribution Center

Natural Resources Building

607 East Peabody Drive

Champaign. Illinois 61820

Citation:

Huhndorf. S.M. 1992. Systematics of Leptosphaeria species found on the Rosaceae. Illinois Natural History Survey Bulletin 34(5):479-534.

Editor: John P. Ballenot

Author's current address: The New York Botanical Garden. Bronx. NY 10458.

US 1SSN 0073-4918

Printed by Authority of the State of Illinois

(X0415-1,200-5-92) 


\section{Contents}

Acknowledgments iv

Introduction 479

Materials and Methods 480

Discussion of Characters 480

Leptosphaeria Species Referable to the Pleosporales 482

Leptosphaeriaceae 482

Phaeosphaeriaceae 492

Lophiostomataceae 503

Leptosphaeria Species Referable to the Melanommatales 505

Leptosphaeria Species Referable to the Dothideales 508

Dothioraceae 508

Pseudosphaeriaceae 510

Leptosphaeria Species Referable to the Hymenoascomycetes 518

Clypeosphaeriaceae 518

Diaporthaceae 520

Amphisphaeriaceae 520

Species incertae sedis 525

Appendix: Leptosphaeria Species Described from the Rosaceae 526

Literature Cited 532

Index to Taxa 534 


\section{Acknowledgments}

This research was supported by National Science Foundation grant BSR 87-00065 to C.A. Shearer, J.L. Crane, and D.L. Swofford and by the Floyd Ingersoll Fellowship, Department of Plant Pathology, University of 11 linois, Fall 1989. The Friends of the Farlow Fellowship supported research on specimens at the Farlow Herbarium, and the H.H. Ross Memorial Grant from the Illinois Natural History Survey supported research on specimens at the New York Botanical Garden. I would also like to acknowledge and thank the Morton Arboretum for the
Baker Fellowship, which helped in the completion of the manuscript. I thank the curators of the herbaria for the material made available for study. I thank J.L. Crane. D.A. Glawe, and M.E. Barr Bigelow for reviewing the manuscript.

This work was originally part of a dissertation submitted to the Graduate College of the University of Illinois at UrbanaChampaign in partial fulfillment of the requirements for the degree of Doctor of Philosophy in plant pathology. 
The genus Leptosphaeria was established by Cesati and de Notaris (1863) to include 26 species. The original description was superficial by modern standards and relied primarily on ascospore characteristics to delimit the genus. Cesati and de Notaris described ascospores as oblong or fusoid. two- to manycelled, and hyaline becoming yellow to dark brown. Because other structural features were poorly defined, a wide range of ascomycetes has been included in this genus. The 1,689 taxa described in Leptosphaeria (Crane and Shearer 1991) represent, according to current concepts of ascomycete classification, a mixture of Hymenoascomycetes and Loculoascomycetes. Crane and Shearer (1991) and Müller (1950) provide good reviews of the historical background of the genus Leptosphaeria. Holm (1957) and Shoemaker (1984a) consider a limited number of species.

A large number of intergeneric transfers of Leptosphaeria species have been made in the past 50 years. Five genera-Phaeosphaeria Miyake. Paraphaeosphaeria Eriksson,

Nodulosphaeria Riess, Entodesmium Riess, and Ophiobolus Riess-have become accepted repositories for many Leptosphaeria species (Holm 1957: Leuchtmann 1984; Shoemaker 1976. 1984a,b). Paraphaeosphaeria.

Nodulosphaeria, and Entodesmium are well defined by several morphological features, including ascocarp wall structure and ascospore characteristics (Shoemaker 1984b, Shoemaker and Babcock 1985). Phaeosphaeria is separated from Leptosphaeria by several morphological characters and host specialization but has itself become a very large and diverse genus (Shoemaker and Babcock 1989b). Ophiobolus species intergrade with long-spored species of Leptosphaeria (Shoemaker 1976). For a key to genera variously allied with Leptosphaeria, see Shoemaker (1984a) or Leuchtmann (1984).
Holm (1957) considered 62 species of Leptosphaeria and restricted the genus to those species most similar to the type of the genus, Leptosphaeria doliolum (Pers.:Fr.) Ces. \& de Not. He emphasized the anatomy of the ascocarp wall and found that in most Leptosphaeria species the wall consisted of thick-walled cells termed scleroplectenchyma. He also emphasized the identity of the substrate and the structure of the ascocarp relative to the substrate in relegating a number of

Leptosphaeria species to other genera. Excluded species were distributed in Nodulosphaeria, Phaeosphaeria, and Entodesmium. He gave considerable weight to the family of host plants in distinguishing these genera. Holm's (1957) scheme was accepted by Shoemaker (1984a) in his treatment of Canadian species of Leptosphaeria.

In recent years, Leptosphaeria has been included in various orders in the Bitunicatae or the Loculoascomycetes. Luttrell (1973) placed Leptosphaeria in the family Pleosporaceae of the Pleosporales. The single order Dothideales was used by von Arx and Müller (1975) for all fungi classified as Loculoascomycetes; they retained Leptosphacria in the Pleosporaceae. Eriksson and Hawksworth (1986) classified the genus in the family Phaeosphaeriaceae of the Dothideales. Barr (1987a) placed

Leptosphaeria in the family Leptosphaeriaceae of the Pleosporales. Most recently, Eriksson and Hawksworth (1990) accepted the family Leptosphaeriaceae in the order Dothideales. Barr's classification of the Ascomycota ( 1983. 1987a) is employed in this dissertation because of its relationship to previous classification schemes (Luttrell 1973) and its detailed explanation of the relationship of taxa. Barr's orders and families are based upon combinations of developmental and morphological characteristics that reflect the widespread diversity within the group. Barr's classification provides a key to higher taxa and is practical 
for adentufication and for determining the plitcenent of organisms not yet included in the scheme.

The present research reassesses the taxonomic position of species of Leptosphaeria described from plants in the family Rosaceae. In doing so, this work cmphasizes a concept of Leptosphacria based on its type specics. Because discrete groups of morphologically similar species were found on related hosts (Noclulosphaeria on Compositae, Phaeosphaeria on Gramineae and Entodesmium on Leguminosae), a goal of the study was to determine whether a distinct group of related species could be found on Rosaceous hosts. Also, approaching the taxonomy of this large, complex genus on the basis of host family is a convenient way of dividing the large numbers of Leptosphaeria species into smaller, workable groups.

Fifty-five species described from Rosaceous hosts have been included in Leptosphacria (see appendix). Efforts were made to locate and obtain type material for all of the described species. The names of herbaria providing material are abbreviated in this dissertation according to Index

Herbariorum (Holmgren et al. 1990). When possible, type specimens were studied, supplemented by other collections, and the species were redescribed and illustrated from the type material. Unfortunately, type material could not be located for all of the species; in such cases, descriptions were based on other material only when the resulting concept of the species was obviously in accordance with the original description. From this work, it became apparent that no discrete group of related species is specialized on the Rosaceae. The species studied were determined to represent a mixture of Loculoascomycetes and Hymenoascomycetes, and non-Leptosphaeria species were reassigned to more appropriate genera.

\section{Materials and Methods}

Several techniques were employed to assess characier states of specimens. Fungi were observed microscopically in water mounts for details of asci, ascospores, hamathecium. centrum. and ascocarp wall surface. using briglutfield and Nomarski differential interferenee contrast. India ink was used as a negative stain to reveal ascospore sheaths. Melzer's reagent $(0.5 \mathrm{~g}$ iodine, $1.5 \mathrm{~g} \mathrm{KI} .20 .0 \mathrm{~g}$ chloral hydrate. $20.0 \mathrm{~m}$ ] distilled water) was used to observe amyloid reactions in unitunicate asci. Semipermanent mounts were made in lactophenol, and many of the photomicrographs were made from these mounts. Micrographs were made using Kodak T Max 100 and Kodak Technical Pan film 2415 (Eastman Kodak Company, Rochester, New York). For scanning electron microscopy. dry ascocarps and substrate were used direct from the herbarium specimen, without any preparation. Specimens were viewed with an Amray 1830 scanning electron microscope.

The order of septation in ascospores is given following Shoemaker (1984a). The sequence of septation is recorded chronologically, with 1 being the first septum formed. A series of numbers separated by colons indicates the sequence in which the septa form. The first number represents the septum nearest the ascospore apex, and the last number is the septum nearest the base. Unusual or infrequent occurrences are recorded within parentheses (Shoemaker 1984a).

To observe details of ascocarp anatomy, semi-thin sections of the ascocarp were needed for light microscopy. Fixation and embedding techniques for plastic were developed to obtain good, uniform sections from dried fungal material in a relatively short period of time. The techniques for fixation and embedding are given in Huhndorf (1991).

\section{Discussion of Characters}

Semi-thin sections of ascocarps were used to assess characteristics of the ascocirp walls. Wall characteristics have proved useful in taxonomic placement of species but may have limitations in the routine identification of specimens. It may be possible to observe this feature with hand sections or frozen microtome sections, as done by Shoemaker (1984a). Ascocarp walls of cells radiating in surface view (textura prismatica) and thick-walled cells (scleroplectenchyma) are good indicators within Leptosphacria of alliance with $L$. doliolum. Wall cells in surface view are seen easily from crush mounts. Semi-thin sections and scamning electron microscopy give a good indication of the relationship of the ascocarp to the substrate. This character has also proved 
important in delimiting Leptosphaeria; included species have ascocarps that are superficial or that become superficial. Semi-thin sections also show ostiole structure, a characteristic that is important in related genera such as Nodulosphaeria.

Ascospore characters. in combination with other characters, are useful for placement of species. Leptosphaeria species have more or less fusiform, three- to multi-septate ascospores with some pigmentation. These character states are continuous rather than discrete, and in practice, divisions are made in a somewhat arbitrary manner. Also, ascospore pigmentation varies within a species and may reflect age, environmental influences, and/or substrate. Ascospore wall ornamentation often is difficult to assess, especially when using type material, which frequently is old and in poor condition. In addition, type material is usually of uniform developmental stage and frequently is sparse and depleted by the activities of previous researchers. Ascospore wall ornamentation is difficult to assess with the light microscope because of the limits of resolution, except in cases for which there may be unusually distinctive surface ornamentation. Using the scanning electron microscope to resolve surface features requires sufficient material of an appropriate developmental stage, with the ascospores released from the asci and with surface detail not obscured by sheaths or mucilaginous material. Unfortunately, this situation does not usually exist in type material. In recent collections with different developmental stages it is easier to view ascospore wall ornamentation. Although the taxonomic significance of this character is unclear at this time, largely because of the difficulties involved in studying it, further studies would be useful.

The importance of host specificity or substrate preference in delimiting species or genera needs further clarification. Whether substrate preference does occur and can be used as a taxonomic character can he demonstrated only by extensive collection and comparison of species from a varicty of substrates, hy comparative study of the morphology of pure cultures of species obtained from a variety of substrates and grown under identical environmental conditions, and by determining experimentally the range of substrates on which isolates of species will grow and reproduce.
The structure of the interascal filaments, part of what Eriksson (1981) termed the hamathecium, plays an important role in distinguishing members of the Melanommatales from those in the Pleosporales according to Barr's (1987a) classification. Only one member of the Melanommatales was found in this group of species, and the diagnostically important trabeculate pseudoparaphyses were difficult to recognize. It was placed in that group because of a combination of other characters. The distinction between cellular pseudoparaphyses (filaments that appear septate at $450 \times$ magnification and branch and anastomose) and trabeculate pseudoparaphyses (thin filaments that do not appear septate at $450 \mathrm{x}$ magnification and branch and anastomose) seems to be clear only in certain cases; the pseudoparaphyses often appear as continuous, rather than discrete, character states.

Trabeculate pseudoparaphyses can be mistaken for cellular ones if septa appear regularly and anastomoses are sparse.

Ascus morphology, emphasized by Eriksson (1981), was not employed in this study because of the difficulty in observing modes of ascus dehiscence and details of ascus wall layers in type and other herbarium specimens. Also, in most cases, the use of stains to enhance ascus wall layers gave virtually no results. 


\section{Leptosphaeria Species Referable to the Pleosporales}

All of the species in this chapter belong in the Pleosporales (sensu Barr 1987a) and share a combination of character states, any one of which may deviate somewhat for a particular taxon. These characters include cellular pseudoparaphyses, asci in a basal layer, a peridium that is usually pseudoparenchymatous, and bipolarly asymmetrical ascospores. The families included within the order are the Leptosphaeriaceae, Phacosphaeriaceae, and Lophiostomataceae.

\section{Leptosphaeriaceae}

The Leptosphaeriaceae as defined by Barr (1987a) include five genera united by the characters of coelomycetous anamorphs, asci that are narrower and thinner-walled than in the Pleosporaceae, and ascocarp walls that consist of relatively large. thick-walled or scleroplectenchymatous cells. The only genus in the family treated here is Leptosphacria.

Leptosphacria V. Cesati \& G. de Notaris, Commentario della Societa Crittogamologica Italiana, Milan 1:234. 1863. Nomen conservandum.

Lectotype: Sphacria doliohum C.H. Persoon: E.M. Fries.

Ascocarps scattered or clustered, superficial or immersed beneath epiclemis, becoming superficial ats epidermis is shed, conic globose. subglobose or depressed, glabrous, papiliate. Ascocarp wall of ten of radiating textura prismatica in surface view; in longitudinal section usually more than three cells thick. composed of scleroplectenchyma, often with an external crust. Papilla central, short, sometimes longer and beaklike, without hyaline periphyses. I'seudoparaphyses broad or narrow, septate, anastomosing, with or without guttules, septal thickenings. and gelatinous coating. Asci bitunicate, numerous in a broad basal hymenium, cylindrical to clavate. shortstalked, 8-spored in most, with spores often biseriate or overlapping uniseriate. Ascospores fusiform, clavate, 3 or more septate, primary septum often median and often constricted. some shade of yellow or brown, appendages or sheath may or may not be present. Anamorphs coelomycetous where known (see Crane and Shearer 1991).

The concept of Leptosphaeria accepted here is essentially that of Holm (1957), later adopted by Shoemaker (1984a) with some modification. The lectotypification of $L$. doliolum (Shearer et al. 1990) represents a basis for circumscribing the genus. More emphasis is placed on scleroplectenchyma found in the ascocarp walls than is considered important by Shoemaker (1984a). As Shoemaker (1984a) noted, thin sections are essential to show this thick-walled cell structure in which the lumen of the cells is very small. Emphasis is also placed on the wall tissue arrangemients in surface view, described using the textura types of Korf (1958). Species having a tissue arrangement similar to that of $L$. doliolum. of cells radiating in surface view. (textura prismatica), are regarded as most typical, but species without this character state are not necessarily excluded. The position of the ascocarp relative to the substrate is very important. with included species having either superficial ascocarps or incocarps immersed beneath the epidermis and becoming superficial as the epidermis is shed. Because only type or herbarium specimens were studied, anamorphs were not considered because cultures could not be made from this dead material.

Examination of 28 purported species of Leptosphaeria from the Rosaceae revealed five species that fit the adopted generic concept. The excluded species are treated following these five species. 
Key to species of Leptosphaeria on the Rosaceae

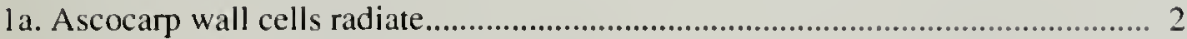

lb. Ascocarp wall cells randomly oriented....................................................... 4

2a. Ascocarp superficial or immersed becoming superficial, ascospores mature inside centrum....................................... 3

2b. Ascocarp immersed beneath host cuticle, ascospores mostly maturing on substrate surface.

L. umbrosa 3a. Neck papillate, short conic, ascospores narrowly fusiform, 22-28 $\times$ 4-5 $\mu \mathrm{m}$. L. doliolum

3b. Neck cylindrical, beaklike, ascospores broadly fusiform, 17-20 $\times 5-8 \mu \mathrm{m}$.

L. praetermissa

4a. Ascocarp immersed-subepidermal, wall pseudoparenchyma, or partly scleroplectenchyma, on leaves of Cercocarpus (provisionally retained within Leptosphaeria)..... L. cercocarpi

4b. Ascocarp erumpent to superficial, wall scleroplectenchyma, on Dryas L. dryadophila

-Leptosphaeria doliolum (C.H. Persoon:E.M. Fries) V. Cesati \& G. de Notaris, Commentario della Societa Crittogamologica Italiana, Milan 1:234-235. 1863. See Figure 1.

ESphaeria doliolum C.H. Persoon:E.M. Fries, lcones et Descriptiones Fungorum Minus Cognitorum, p. 39. 1800; E.M. Fries, Systema Mycologicum Sistens Fungorum 2:509. 1823.

= Leptosphaeria rustica P.A. Karsten, Fungi Fenniae Exsiccati, Century 10. No. 964. Anno 1870.

\section{$\equiv$ Metasphaeria rustica (P.A. Karsten)}

P.A. Saccardo, Sylloge Fungorum Omnium Hucusque Cognitorum Digessit P.A. Saccardo 2:157. 1883.

Ascocarps scattered, sparse, immersedsubcuticular to erumpent, papillate, glabrous to tomentose at base, globose, flattened at base, 300-325 $\mu \mathrm{m}$ diameter, $250-300 \mu \mathrm{m}$ high. Ascocarp wall of textura prismatica in surface view, composed of cells radiating from apex outward; in longitudinal section $45-55 \mu \mathrm{m}$ thick at sides, 20-27 $\mu \mathrm{m}$ thick at base. composed of 12-15 layers of hyaline, polygonal, isodiametric, scleroplectenchymatic cells (3.6$6.5 \mu \mathrm{m}$ diameter), outer 2-3 layers somewhat brown-melanized, with an external brownmelanized crust. Papilla broadly rounded, not fully formed, $130-135 \mu \mathrm{m}$ high, $70-75 \mu \mathrm{m}$ wide; wall $40-50 \mu \mathrm{m}$ thick, composed of 15-20 layers of small, brown-melanized, thick-walled, polygonal, isodiametric celts $(2.5-6.5 \mu \mathrm{m}$ diameter), outer layers heavily brown- melanized, inner layers hyaline, surrounding a 20-25 $\mu \mathrm{m}$ wide immature circular ostiole formed from small hyaline cells, without periphyses. Pseudoparaphyses $1.0-2.0 \mu \mathrm{m}$ wide, 150-175 $\mu \mathrm{m}$ long (height of the ascocarp cavity), numerous, narrowly cellular, with guttule-like thickenings at septa, without gelatinous coating. Asci $90-125 \times 5-9 \mu \mathrm{m}$, numerous, basal, cylindrical-clavate, with 8 overlapping uniseriate ascospores. Ascospores 22-28 x 4-5 $\mu \mathrm{m}$, narrowly fusiform, with acute end cell shape, second cell slightly enlarged, straight to slightly curved, 3-septate, septa evenly distributed, order of septation $2: 1: 2$, primary septum median and slightly constricted; light brown, guttulate, without appendages, surrounded by gelatinous material.

Lectotype: As Sphaeria doliolum Pers., 9]0.270-650 (L).

Exsiccatae: FinLAnd: Tammela, on Spireae ulmaria L. (=Filipendula ulmaria Maxim.), Sept., Fungi Fenniae Exsiccati, Century 10, No. 964 (isotype of L. rustica, H, FH).

Comments: The collections of L. rustica, on stems of Spiraca ulmaria L. in both of the exsiccatae sets, were immature. No ascospores were found, and asci were only beginning to form. Karsten (1873) describes the ascospores as elongate-fusoid, subhyaline, uniseptate with several guttules in each cell, and 30-36 x 5-6 $\mu \mathrm{m}$ in size. Ile probably described immature spores. This information-along with the 


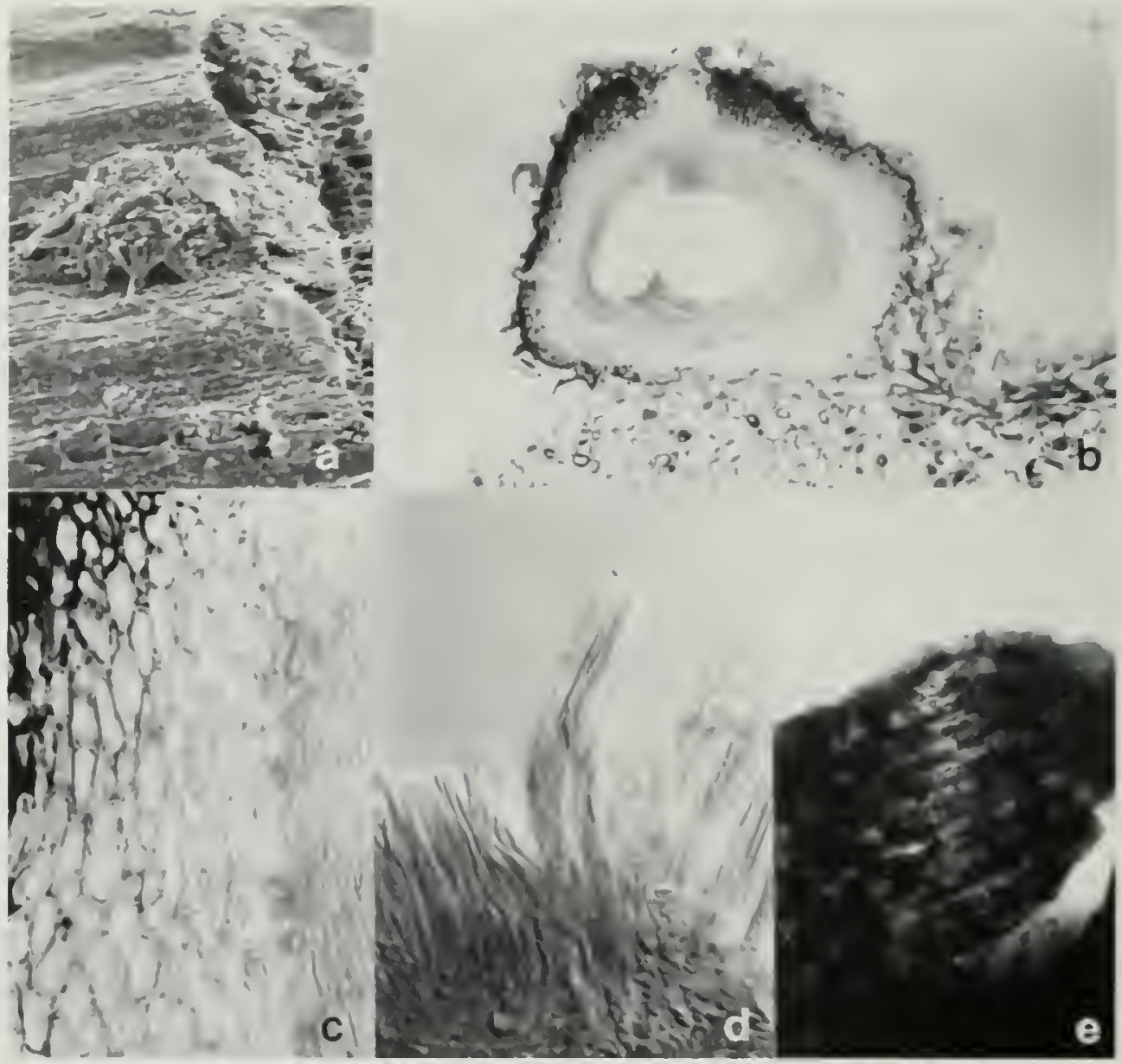

Figure 1. Leptosphaeria doliolum. a. SEM of erumpent ascocarp. $x$ ]25. b. longitudinal median section through ascocarp, $\times 150$. c. longitudinal, median section through ascocarp wall, $\times 950$. d. ascus, $\times 525$. e. ascocarp wall surface with radiating cells, $\times 550$. All from isotype of $L$. rustica.

radiating wall cells in surface view, the scleroplectenchymatic wall cells in section. and the location of the ascocarp relative to the substrate-is consistent with the character of $L$. doliolum, the type of the genus. Leprosphaeria doliolum is found on many dead herbaceous stems, although not previously described from Spiraca.

- Leprosphaeria divadophila S.M. Hulındorf nom. nov. See Figure 2.

Etymology: Gr. philos = having affinity for. $\equiv$ Melanomma driadis C.J. Johanson in Rahenhorst, Fungi europaci no. 3659 $(\mathrm{I} 890)$. (Basionym).

= Leprosphacria dryolis E. Rostrup.

Botanisk Tidsskrift 25:305. 1903.
Ascocarps clustered, erumpent to superficial. papillate. glabrous to slightly tomentose toward base, tomentum of dark brown hyphae. conicglobose, 150-250 $\mu \mathrm{m}$ diameter. 180-275 $\mu \mathrm{m}$ high. Ascocarp wall of textura angularis in surface view: in longitudinal section uniformly 12-20 $\mu \mathrm{m}$ thick (up to $27 \mu \mathrm{m}$ thick near apex). composed of 4-5 layers of polygonal. isodiametric to slightly elongate. scleroplectenchymatic cells, outer 2-3 layers composed of brown-melanized cells $(3.5-4.3 \times 5.5-6.8 \mu \mathrm{m})$. inner 2-3 layers composed of hyaline. compressed cells $(2.1-3.5 \times 10.0-12.3 \mu \mathrm{m})$. Papilla conical, 60-65 $\mu \mathrm{m}$ high. 25-50 $\mathrm{mm}$ wide at the apex. 90-110 1 m wide at the base. composed of 7-9 layers of isodiametric cells (2.8-3.6 ftm diameter), wall $10-12 \mu \mathrm{m}$ thick surrounding a $35-45 \mathrm{tm}$ wide ostiole without 


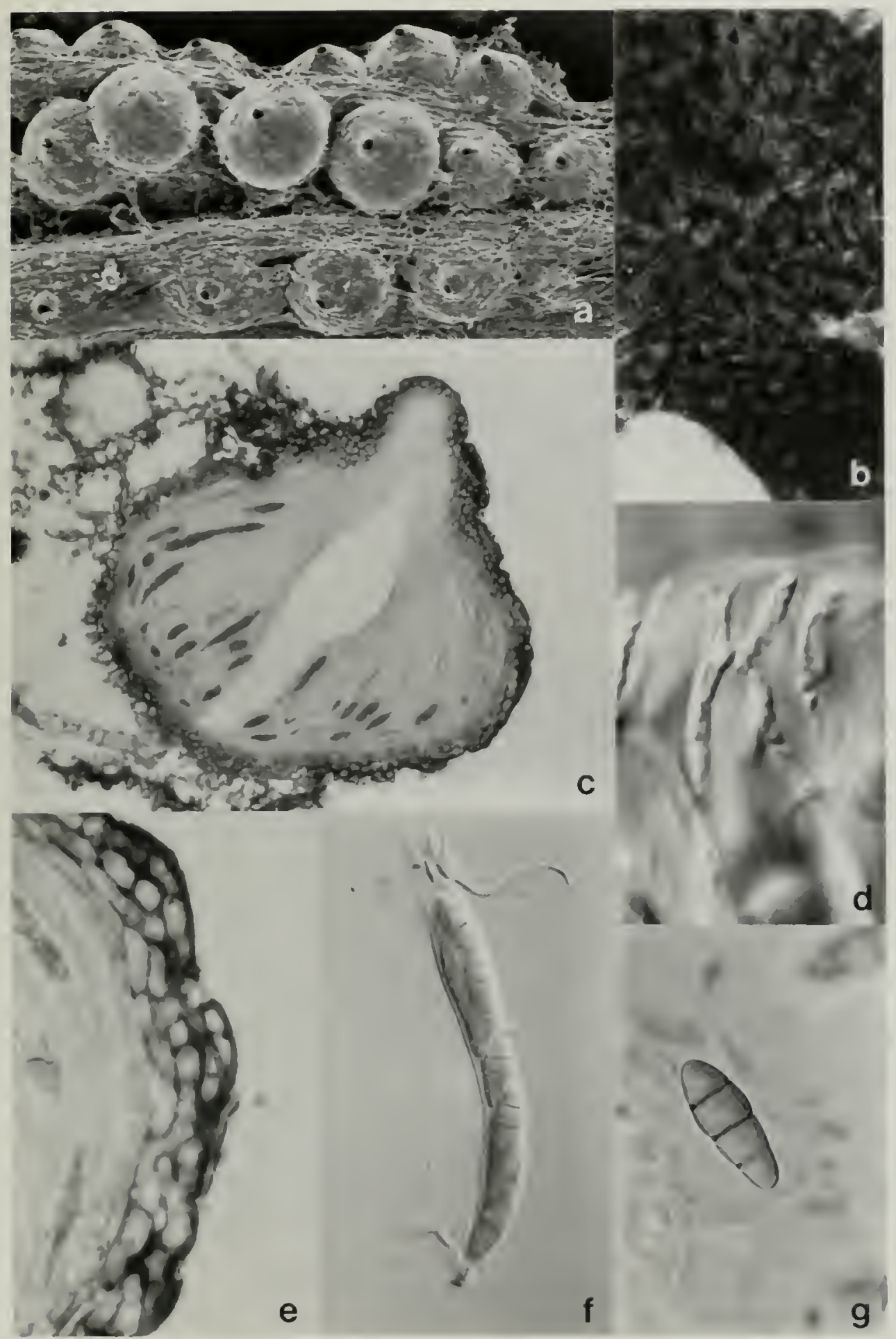

Figure 2. Leptosphaeria dryadophila. a. SEM of crumpent ascocarps, $\times 50$. b. ascocarp wall surface, $\times 550$. c. longitudinal median section through ascocarp, $\times 250$. d. cellular pseudoparaphyses, $\times 2,000$. e. longitudinal median section through ascocarp wall, $x 950$. $f$. ascus, $\times 500$. g. ascospore, $x 1,150$. a, c. c, and $f$ from holotype of $L$. dryadis; b, d, and g from isotype of $L$. dryadophila. 
pcriphyses. Pseudoparaphyses $0.7-3.0 \mu \mathrm{m}$ wide, $110-175 \mu \mathrm{m}$ long (height of the ascocarp cavity), numerous, narrowly cellular, with gelatinous coating. Asci (72-)90-118 $18.8-$ 13.6 $\mu \mathrm{m}$. numerous, basal to slightly lateral. cylindrical, thin-walled but with a thickened rounded apex, short-stalked, with 8 biseriate ascospores. Ascospores 20.1-24.5 × 5.7-7.2 $\mu \mathrm{m}$, fusiform to slightly clavate, with acute end-cell shape, slightly curved; 3(-4-5)-septate, septa evenly distributed, order of septation 2:1:2(:3:4), without constrictions: pale brownish yellow, with ornamented wall, without sheath or appendages.

Isotype: Sweden: Jamtland. Renfjallet. c. 900m, in fructibus et calycibus emortuis Dryadis octopetalae L. 13, Juli 1884, leg. C.J.

Johanson, Rabenhorst, Fungi europaei no. 3659 (1890) (FH, NY).

Exsiccatae: Sweden: Jamtland, Renfjallet. 13. Juli 1884, leg. C.J. Johanson. Vgr., Micr. rar. sel. 105 (FH).

Other material examined: ICELAND: Sponsgerdi, on Dryas octopetala, Juli 12, 1901, O.

Davidson (type of Leptosphacria dryadis, C).

Comments: This fungus was originally described in Melanomma and was retained with some reservation in that genus by Holm ( 1957. 1979). who stated, "The species is hardly a Melanomma but its true affinities are doubtful to me." Melanomma dryadis differs from the current concept of Melanomma (Barr 1987a) in not having asci that arise peripherally within the centrum and not having trabeculate pseudoparaplysses. Barr (1982) erected the genus Bricookea for a biologically similar species, Bricookea sepalorm (Vleugal) Barr. which is found on the inflorescences of Juncus species. Melanomma dryadis differs from this fungus in several respects: cells of the ascocarp wall are scleroplectenchymatous. not pseudoparenchymatous; the ascocarp apex opens by a pore, not by a slit: and the ascospores are not hyaline. Melanomma dryadis, occurring in and on the dead flowers and fruits of Dryas octoperala, is a true Leptosphacria. having the characteristics of an erumpent to superficial ascocarp with a wall of scleropletenchymatous cells and 3-septate yellow-brown ascospores. It does not. however. show the radiating arrange- ment of cells of the ascocarp surface characteristic of $L$. doliolum. Because the epithet dryadis is pre-empted in Leptosphaeria by $L$. dryadis Rostrup, a new name, Leptosphaeria dryadophila is proposed for Melanomma dryadis Johanson.

\section{- Leptosphaeria praetermissa (P.A. Karsten)}

P.A. Saccardo. Sylloge Fungorum Omnium Hucusque Cognitorum Digessit P.A. Saccardo 2:26. 1883. See Figure 3. ESphaeria praetermissa P.A. Karsten, Fungi Fenniae Exsiccati, Century 9, No. 852. Anno 1869.

Ascocarps clustered, sparse, immersedsubepidermal becoming erumpent, papillate. glabrous to tomentose at base. globose, flattened at base, 350-625 $\mu \mathrm{m}$ diameter. 300 $500 \mu \mathrm{m}$ high. Ascocarp wall of textura prismatica in surface view, composed of cells radiating from apex outward: in longitudinal section uniformly $32-58 \mu \mathrm{m}$ thick at sides and base, composed of 7-8 layers of hyaline, polygonal, isodiametric, scleroplectenchymatic cells $(5.7-13.6 \times 3.6-7.2 \mu \mathrm{m})$, inner 2-3 layers somewhat elongate and compressed. with an external brown-melanized crust. Papilla beaklike, cylindrical, erumpent, $120-180 \mu \mathrm{m}$ high. 75-135 $\mu \mathrm{m}$ wide: wall 25-36 $\mu \mathrm{m}$ thick. composed of 5-6 layers of small, brownmelanized, thick-walled, polygonal, isodiametric cells (4.3-7.2 $\mu \mathrm{m}$ diameter). surrounding a 35-80 $\mu \mathrm{m}$ wide circular ostiole formed from small hyaline cells. without periphyses.

Pseudoparaphyses 1.0-2.0 $\mu \mathrm{m}$ wide. 180-260 $\mu \mathrm{m}$ long (height of the ascocarp cavity). numerous, narrowly cellular. without gelatinous coating. Asci $100-130(-150) \times 7-13 \mu \mathrm{m}$. numerous. basal, cylindrical. thin-walled, shortstalked, rounded apex with apical chamber present, with 8 biseriate ascospores. Ascospores $17-20(-25) \times 5.5-8.0 \mu \mathrm{m}$, broadly fusiform, end cells acute to rounded. straight to slightly curved: 3 -septate, septa evenly distributed, order of septation $2: 1: 3$ or 2:1:2. primary septum median, with constrictions at all septa. second cell occasionally enlarged (wider): brownish-yellow, smooth. without sheath or appendages.

Isotype: FivLAyD: In caulibus emortuis $R$ uhi odorati et $R$. iduet in par. Tammela sat fre- 


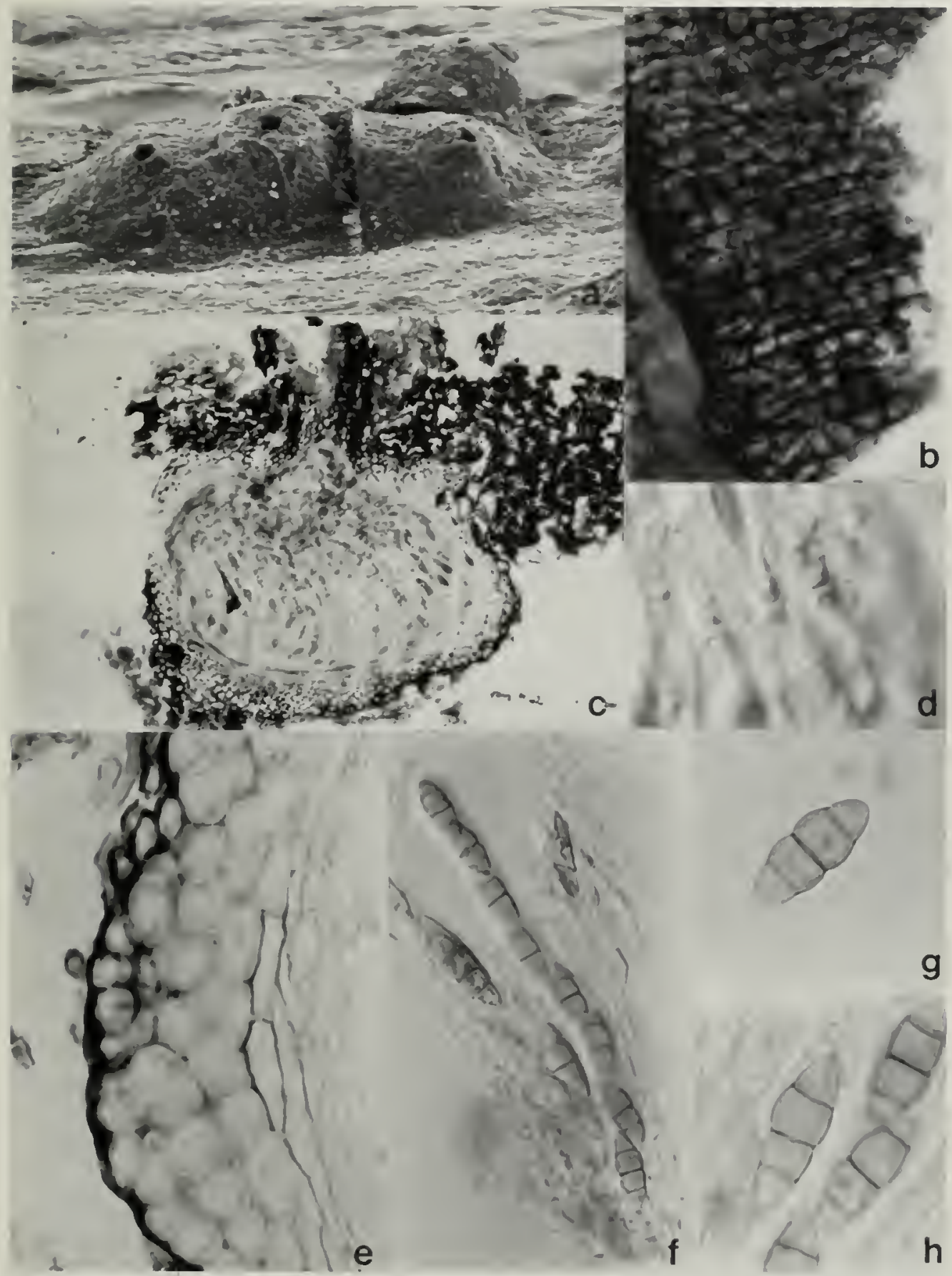

Figure 3. Leptosphaeria praetermissa. a. SEM of erumpent ascocarps, $x 65$. b. ascocarp wall surface with radiating cells, $x 550$. c. Iongitudinal median section through ascocarp, $x] 50$. d. cellular pseudoparaphyses. $\times 2,000$. e. longitudinal median section through ascocarp wall, $\times 950$. f. ascus, $\times 525$. $g$, h. ascospores, $x 1,150$. All from isotype of $L$. pruetermissu. 
yuenter per annum ohvia. Fungi Fenniae Exsiccati, Century 9, No. 852 (H. FH).

Other material examined: CANADA: Quebec: Gatineau Provincial Park, Chemin Ridge Road, on Rubus odoratus, 20 Jun. 1987, C.T. Rogerson (NY); SwEDEN: Jemtland: Five collections, all on Rubus ideaus, Leg. A.G. Eliasson, 20 May 1930, 27 Jun. 1930, 17 Jun. 1931, 19 Jun. 1931, 28 Jul. 1931 (S); Umea, Apr. 1908, J. Vleugel (S).

\section{Comments: Leptosphaeria praetermissa} warrants inclusion in the genus because of its large erumpent ascocarp with a wall composed of scleroplectenchymatous cells. As in $L$. doliolum, the wall has an external crust, and the cells form a radiating pattern in surface view. It differs from $L$. doliolum in having a rather long. cylindrical neck that grows through the host epidermis before the ascocarp becomes erumpent. This species seems to be found predominantly in Europe but is probably not common there. It was not encountered in any collections of Rubus sp. in the United States but was found in one collection from Canada.

\section{- Leptosphaeria umbrosa G. Niessl in G.L.} Rabenhorst. Fungi Europaei Exsiccati, Klotschii Herbarii vivi Mycologici Continuatio, Edition 3 (Edita Nova), Series 2. Century 20, No. 1934. Anno 1875; Just's Botanisch Jahresberichte 3:262. 1887. See Figure 4. $\equiv$ Massaria umbrosa (G. Niessl) H. Rehm in P.A. Saccardo, Sylloge Fungorum Omnium Hucusque Cognitorum Digessit P.A. Saccardo 9:761. 1891.

Ascocarps scattered, immersed-subcuticular, papillate, glabrous, globose, flattened at base. 150-300 $\mu \mathrm{m}$ diameter, 90-200 $\mu \mathrm{m}$ high.

Ascocarp wall of textura prismatica in surface view, composed of cells radiating from apex outward: in longitudinal section 4-6 $\mu \mathrm{m}$ thick at the base, composed of thin, liyaline, compressed cells, $10.8-22 \mu \mathrm{m}$ thick at the sides. composed of 5-6 layer's of polygonal. scleroplectenchymatic cells, outer 2-.3 layers of isodiametric to slightly elongate, brownmelanized cells $(3.5 \times 7-10 \mu \mathrm{m})$ surrounded by a hrown-melanized crust, inner 2-3 layers of hyaline, clongate-compressed cclls $(2-3 \times 10-$ 18 4ni). I'apilla bluntly conical, (18-)25-54 $\mu m$ high, 36-56 4 m wide at the apex, 60-70 $\mu \mathrm{m}$ wide at the base, composed of 5-6 layers of small, isodiametric, heavily brown-melanized, thick-walled cells (2-3.6 $\mu \mathrm{m}$ diameter), wall 14.4-22 $\mu \mathrm{m}$ thick surrounding a $25-45 \mu \mathrm{m}$ wide ostiole without periphyses. Pseudoparaphyses $0.7-2.0 \mu \mathrm{m}$ wide, $80-110 \mu \mathrm{m}$ long (height of the ascocarp cavity), numerous. narrowly cellular, with guttule-like thickenings at septa, without gelatinous coating. Asci (72-) $80-100(-117) \times 10.8-15.0 \mu \mathrm{m}$, numerous. basal, cylindrical-clavate, thick-walled. rounded apex with apical chamber, shortstalked, with 8 tri- to biseriate ascospores, most commonly immature. Ascospores 27.3-33.0 x 4.3-7.2 $\mu \mathrm{m}$, hyaline to subhyaline when immature, 28-37.4 x 5.7-9.3 $\mu \mathrm{m}$, pale brown when mature, narrowly fusiform. with acute end-cell shape, slightly curved; 4-septate, septa unevenly distributed, order of septation $2: 1: 2: 3$, primary septum supramedian and slightly constricted, second cell slightly enlarged at maturity, slightly roughened wall, continuous sheath $(0.7-1.5 \mu \mathrm{m}$ thick) surrounding immaiure spore, without appendages.

\section{Holotype: Austria: An Spiraea Aruncus [=Aruncus dioicus (Walt.) Fern.] bei Voitsberg in Steiermark. Septbr. 1874 (M).}

Exsiccatae: Austria: Voitsberg. Steiermark. Septbr., G. v. NiessI, Rabenhorst, F. europaei exs. 1934 (FH, NY isotypes): Voitsberg. Steiermark, Aug. 1882, G. v. Niessl. Rehm, Ascomyceten 690 (FH, NY authentic material): Voitsberg. Steiermark, G. v. Niessl, Weese, Eumycetes sel. exs. $638(\mathrm{FH})$.

Other material examined: Gernaty: Frauenfeld, on Solidago, Ociober (NY).

Comments: Leptosphaeria umbrosa is interesting because initially it seems to resemble members of the Phaeosphaeriaceae having small, pseudoparenchymatic-walled, subcuticular ascocarps that lift the host cuticle on maturity. Upon closer examination. it reveals the characteristic features of Leptosphaeria such as ascocarp walls composed of scleroplecienclyyma surrounded by an external brown crust and wall cells that radiate in surface view. Other distinctive characteristics that may aid in the identification of this species are the wide pseudoparaphyses with prominamt thickenings at the septa and mature 


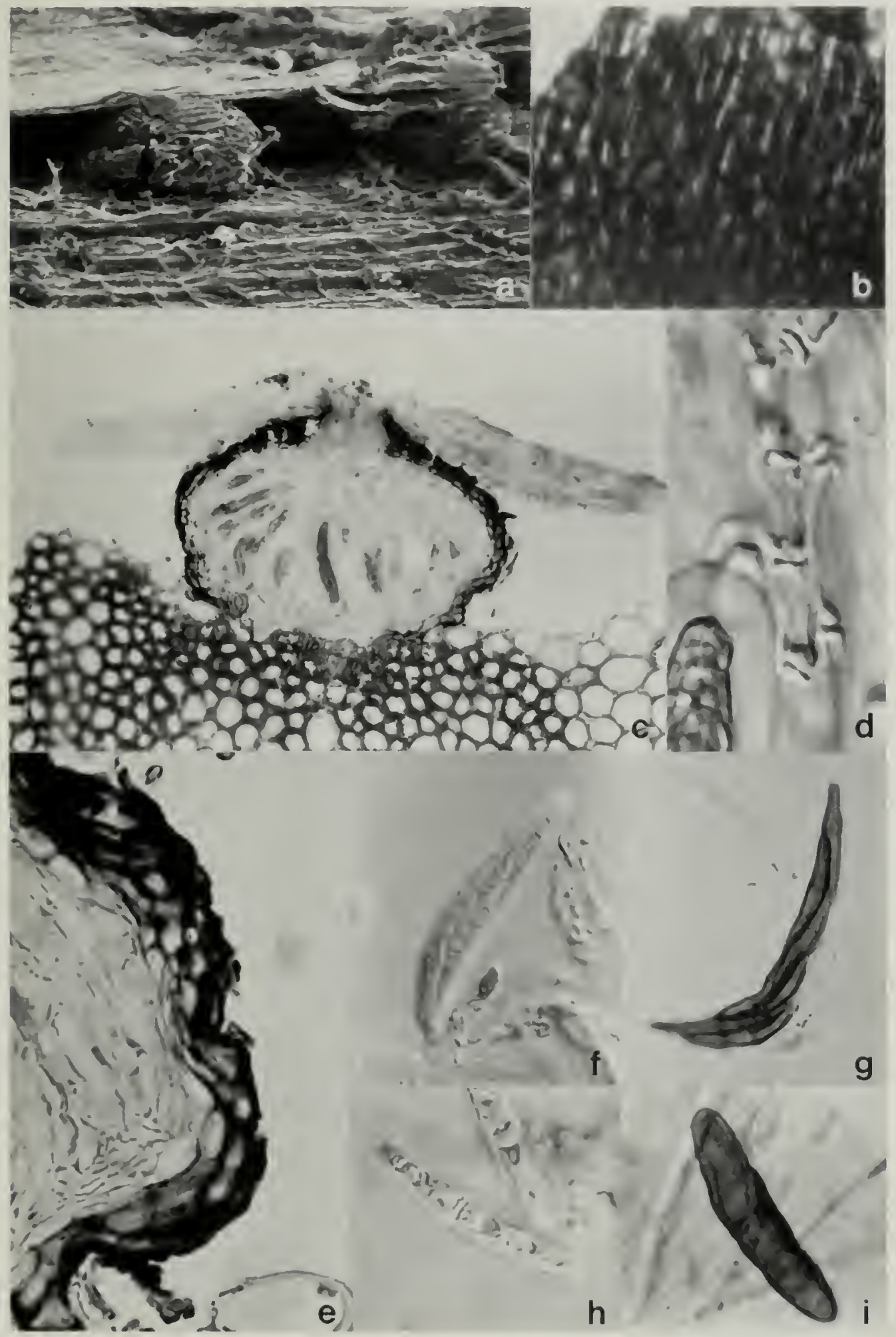

Figure 4. Leptosphacria umbrosa. a. SEM of immersed ascocarns, $\times 150$. h. ascocarp wall surface with radiating cells, $\times 550$. c. longitudinal median section through ascocarp, $\times 200$. d. cellular pseudoparaphyses with thickenings at septa, $\times 2,000$. e. Iongitudinal median section through ascocarp wall. $\times 950$ ). $\mathrm{f}$. ascus with immature ascospores, $\times 525$. g. ascus with mature ascospores, $\times 525 . \mathrm{h}$. immature alscosporc, $\times 1.150$. 
1)rown ascuspores that are often seen only on the surface of the substrate surrounding the ascocarp. Also diagnostic are the thin ascocarp bases often left behind on the substrate when ascocarps are removed from the substrate surface.

- Leptosphaeria cercocarpi H. Sydow \& P. Sydow, Annales Mycologici 5:339. 1907. See Figure 5.

Ascocarps clustered, abundant, immersedsubepidermal, with surrounding stroma extending into substrate, papillate, glabrous, globose, 175-240 $\mu \mathrm{m}$ diameter, 175-240 $\mu \mathrm{m}$ high. Ascocarp wall of textura angularisglobulosa in surface view; in longitudinal section 22-31 $\mu \mathrm{m}$ thick at sides and base, up to $50 \mu \mathrm{m}$ thick near apex, composed of 6-8 layers of polygonal, isodiametric-elongate, pseudoparenchymatic cells $[3.6-7.2 \times 5.4-12.6(-16)$ $\mu \mathrm{m}]$, outer 2-4 layers of brown-melanized cells at sides and base, inner 4-5 layers of hyalinecompressed cells at base. Papilla very short. erumpent, rounded-conical, $31-45 \mu \mathrm{m}$ high, $62-93 \mu \mathrm{m}$ wide, wall $25-30 \mu \mathrm{m}$ thick, composed of 8-10 layers of small, isodiametric. scleroplectenchymatic cells $(2.0-7.2 \mu \mathrm{m}$ diameter), outer 5-6 layers brown-melanized, inner 3-4 layers hyaline, surrounding a 30-40 $\mu \mathrm{m}$ wide circular ostiole without periphyses.

Pseudoparaphyses 1.0-2.0 $\mu \mathrm{m}$ wide, 125-200 $\mu \mathrm{m}$ long (height of the ascocarp cavity), numerous, narrowly cellular, with gelatinous coating. Asci 95-120 x 17-21 $\mu \mathrm{m}$, numerous, basal, cylindrical-oblong, thick-walled, shortstalked, rounded apex, with 8 biseriate ascospores. Ascospores (25-)27-31(-33) × 8.5$11.5 \mu \mathrm{m}$, broadly fusiform to slightly clavate, end cells rounded, straight to slightly curved, 3 -septate, septa evenly distributed, order of septation 2:1:2, primary septum median, slight constrictions at all septit, brown, ornamented walls, without sheath or appendages.

Holotype: United States: In foliis emortuis Cercocarpi ledifolii, Mill Creek Canyon, Salt Lake Co., Utah Americae bor. Ieg. A.O. Garrett no. $677(\mathrm{~S})$.

Other material examined: United States: Utan: Box Elder Co.. One Mile Creek. north side of Raft River Mts.. Aug. 25, 1986: Juals
Co., 5.2 mi up Granite Creek Canyon, east side of Deep Creek Mts, Aug. 26. 1986: Rich Co.. Sunrise Campground. Cache National Forest. Route 89, west of Garden City, July 13, 1985: Weber Co., Malans Peak, Aug. 11. 1972: Weber Co.. south slope of Malans Peak. Wasatch Mts., east of Ogden, July 1, 1976: Weber Co., mouth of Taylor's Canyon, Wasatch Mts.. east of Ogden. May 18, 1972, Apr. 29, 1981, May 6, 1982, all on Cercocarpus ledifolius Torrey in Torrey \& Gray var. intermontamus (Brittonia 39:424. 1987), all C.T. Rogerson (all NY).

Comments: Leptosphaeria cercocarpi is an easily recognized species on Cercocarpus ledifolius. The ascocarps usually entirely cover both surfaces of dead leaves. Retaining this species in Leptosphaeria is not totally satisfactory, but placing it elsewhere is also problematic. Certain characteristics resemble those found in the Phaeosphaeriaceae (sensu Barr 1987a). The ascocarps are small-medium sized and immersed in the substrate, and there appears to be some kind of hyphal growth or stroma surrounding the ascocarps and extending into the substrate. Other characteristics do not coincide with inclusion in that group. Although the lateral walls of the ascocarp of $L$. cercocarpi consist of pseudoparenchymatous cells, they are not thin and soft as is characteristic of the Phaeosphaeriaceae. In fact. the walls in the upper regions of the ascocarp consist of thick-walled scleroplectenchymatous cells. In Barr's (1987a) key to this family, the only two genera in which this fungus could be placed are Phaeosphaeria and Kalmusia. The ascocarps are not small and delicate enough for inclusion within Phaeosphacria, and the current concept includes only species on monocots (Shoemaker and Bahcock 1989b) (but see also the discussions for $P$. pomona and $P$. Lucilla herein). The current concept of Kolmusia. which includes $K$. chensis (see discussion herein), does not adequately accommodate $L$. cercocarpi. Therefore, unlike other leaf-inhabiting species of Leptosphacria belonging elsewhere (i.e., Phacosphaeriaceae), this species is retained within Leptosphaeria because of the larger. rohust nature of the ascocarp and wall. 


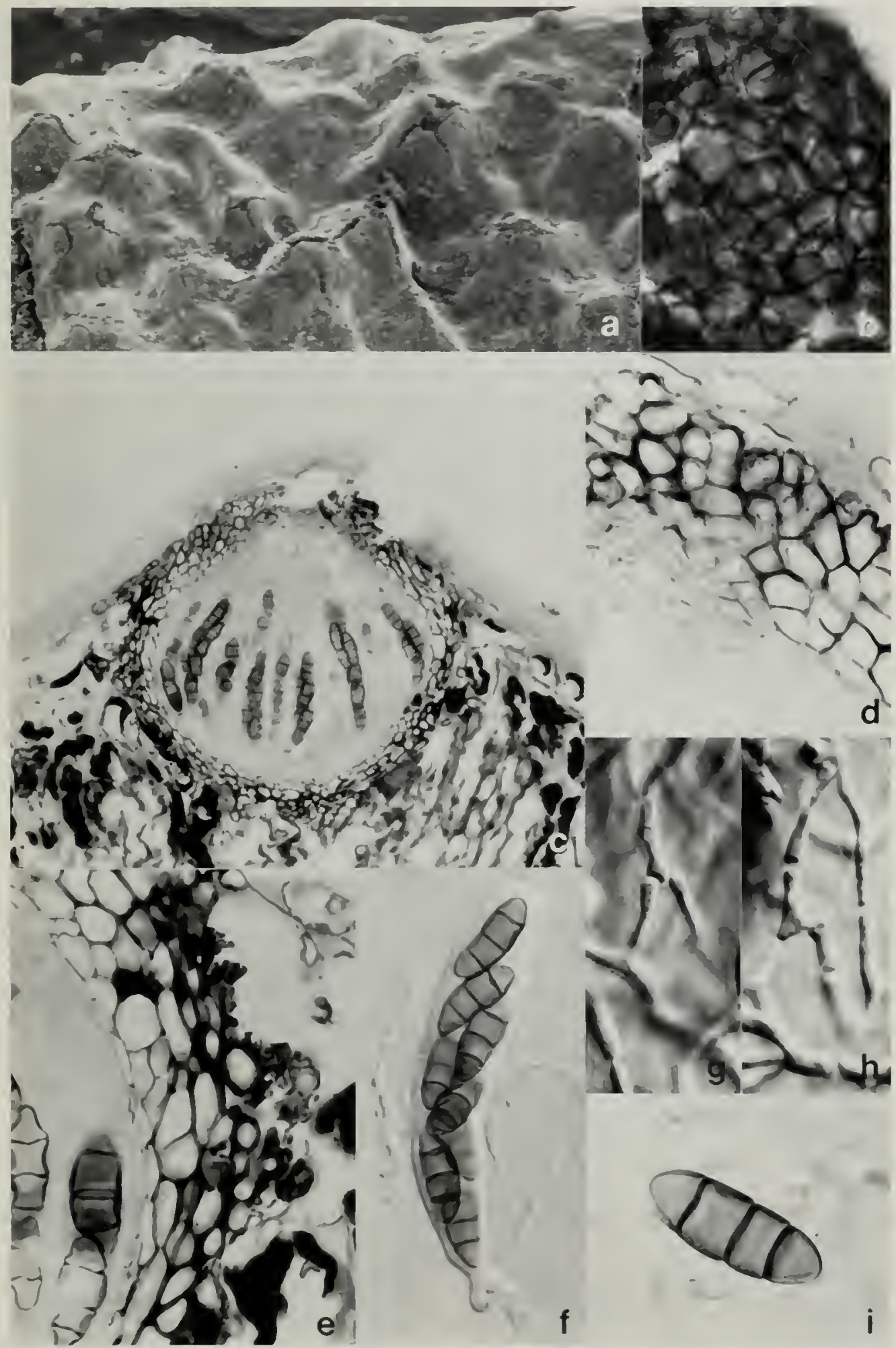

Figure 5. Leptosphaeria cercocarpi. a. SEM of immersed ascocarps, x50. b. ascocarp wall surface, x550. c. Jongitudinal median section through ascocarp. $\times 225$. d. section through ascocilrp wall nech region. $\times 950$. e. Iongitudinal median section through ascocarp wall, $x 950$. f. ascus, $x 525 . \mathrm{g}$. h. cellular pseudoparapliyses, $\times 2.000$. i. ascospore, $x 1.150$. Alt from holotype of 1 . cercecarpi. 


\section{l'hateosphaeriaceae}

The species considered in this section all possess characteristics of the Phaeosphaeriaceae (Barr 1987a). Species in the Phacosphaeriaceae are distinguished from those in the Leptosphaeriaceae by the smaller ascomatal size, the thin, soft ascocarp wall composed of pseudoparenchymatous cells, and the rather sparse pseudoparaphyses (Barr 1987a). The genera represented within the family are Paraphaeosphaeria Eriksson. Phacosphaeria Miyake, and Kalmusia Niessl.

- Paraphaeosphaeria concentrica (J.B. Ellis \& B.M. Everhart) S.M. Huhndorf comb. nov. See Figure. 6.

$\equiv$ Leptosphaeria concentrica J.B. Ellis \& B.M. Everhart. The North American Pyrenomycetes. A Contribution to Mycologic Botany, p. 354. 1892. (Basionym).

Ascocarps scattered, sparse, immersedsubepidermal, globose, papillate, glabrous, 90 $100 \mu \mathrm{m}$ diameter, $100-125 \mu \mathrm{m}$ high. Ascocarp wall of textura angularis in surface view; in longitudinal section $7.2-10.8 \mu \mathrm{m}$ thick at sides and base, composed of 2-3 layers of elongatecompressed, hyaline, pseudoparenchymatic cells $(2.8-3.6 \times 12-14.5 \mu \mathrm{m})$, wall up to $13 \mu \mathrm{m}$ thick near apex, composed of 3-4 layers of isodiametric-elongate. slightly brownmelanized cells $(3.6-5.6 \times 7.2-12.2 \mu \mathrm{m})$. Papilla very short, erumpent, blunily conical. 15-20 $\mu \mathrm{m}$ high, $25-30 \mu \mathrm{m}$ wide, $10-13 \mu \mathrm{m}$ thick near base of papilla, papilla apex wall cells hyaline, thin-walled surrounding a circular ostiole without periphyses. Pseudoparaphyses 1.4-2.0 $\mu \mathrm{m}$ wide. $70-90 \mu \mathrm{m}$ long (height of the ascocarp cavity), numerous, narrowly cellular. without gelatinous coating. Asci (43-)54-66 x 10.8-12.2 $\mu \mathrm{m}$, numerous, basal, cylindricalclavatc, thick-walled, short-stalked, rounded apex, with apical chamber, with 8 biseriate ascospores. Ascospores (14.5-)16.5-18.7 x $(3.6-) 4.3-5.7(-6.5) \mu \mathrm{m}$, cylindrical, with rounded end cells, end cells longer than central cell, straight; 2-septate, septa unevenly distributed, order of septation 2:1, primary septum submedian and constricted; hrown, wall roughened, thin cellular sheath entirely surrounding spore, without appendages.
Holotype: UNited STATES: On apple leaves (Malus sp.). Columbia, Missouri (H. Dorsett). and Louisiana (Langlois) (NY).

\section{Comments: Paraphaeosphaeria species are} distinguished by ascocarps that form below or within the host epidermis. an ascocarp wall consisting of a few layers of pseudoparenchyma, and cylindrical, usually echinulate ascospores with the primary septum forming in the lower half of the spore.

Although Paraphaeosphaeria species are commonly found on monocotyledonous plants. species on dicot plants have also been placed in the genus (Hedjaroude 1969, Shoemaker and Babcock 1985). Such is the case here with Paraphaeosphaeria concentrica described from apple leaves. The description of $P$. concentrica closely resembles the description of the type of the genus. $P$. michotii (Westendorp) Eriksson. with the only difference being the dicotyledonous host plant. Paraphaeosphaeria michotii and its synonyms have so far been found exclusively on monocot hosts (Shoemaker and Eriksson 1967. Shoemaker and Babcock 1985). Overlooking substratum preference, $P$. concentrica would be synonymous with $P$. michotii. Because of the historical value placed on this character and the need for experimental evidence to demonstrate the range of substrata on which species will grow and the total lack of collections of $P$. michotii on dicot hosts. $P$. concentrica is retained as a separate species.

-Phacosphaeria pomona (P.A. Saccardo) S.M. Huhndorf comb. nov. See Figure 7. 三Leptosphaeria (Leprosphaerella) pomona P.A. Saccardo. Nuovo Giomale Botanico Italiano e Bolletino della Società Botanica Italiana 8:176. 1876. (Basionym).

Ascocarps scattered, sparse, immersedsubcuticular, globose, papillate, glabrous to slightly tomentose near base, with loose. dark hyphal growth on host cuticle surrounding ascocarps. (55-)90-125 $\mu$ m diameter, 75-115 $\mu m$ high. Ascocarp wall of textura angularisglobulosa in surface view; in longitudinal section unifonnly' 6.1-7.7 $\mu \mathrm{m}$ thick. composed of 2-3 layers of brown-melanized. compressed. isodianctric-to-elongate pseudoparenchymatous cells $(1.5-2.0 \times 8-12 \mu m)$. Papilla very short, crumpent. bluntly conical, 15-21 $\mu \mathrm{m}$ 


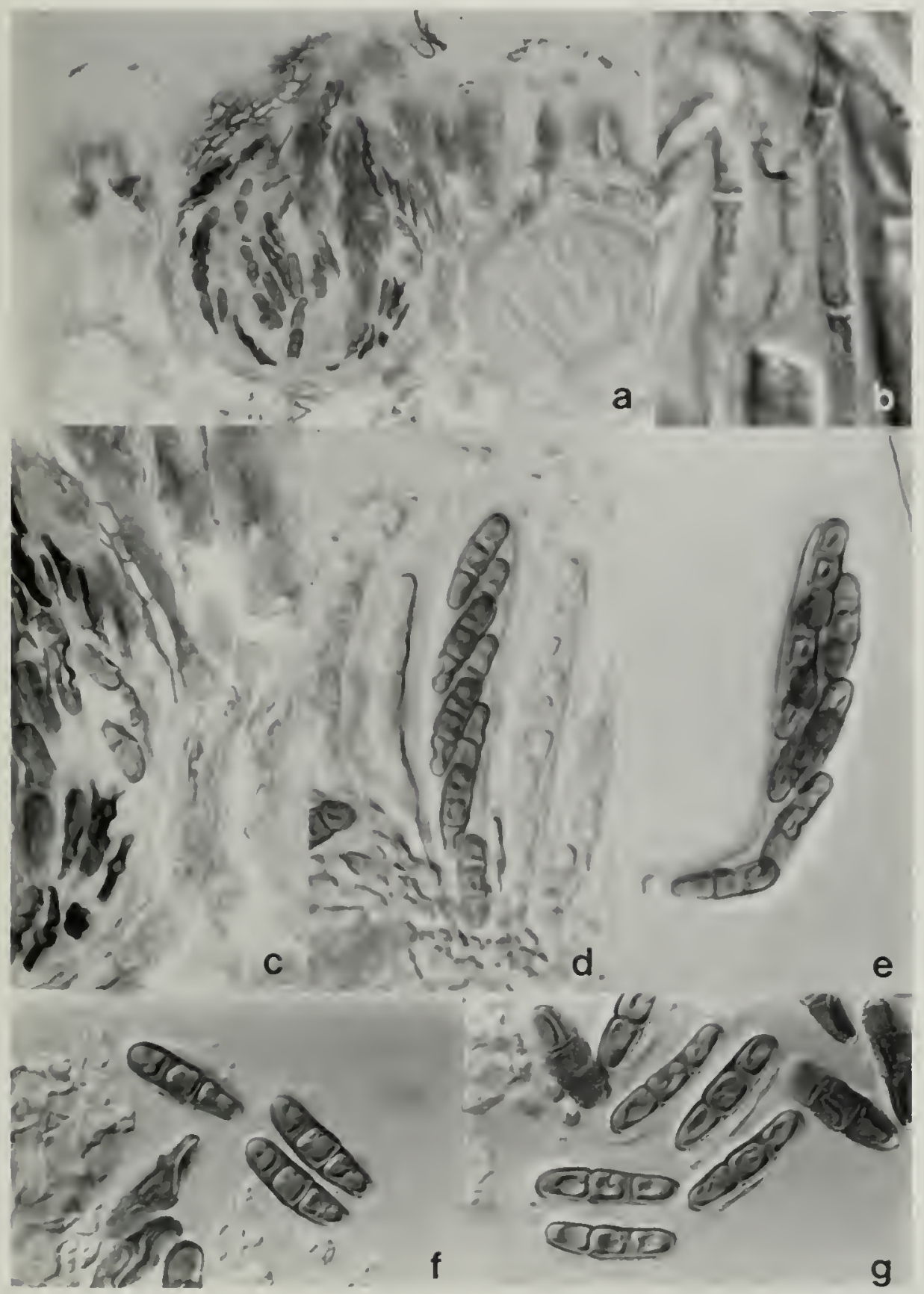

Figure 6. Paraphaensphaeria concentrica. a. longitudinal median section through ascocarp, $\times 375$. b. cellular pseudoparaphyses, $\times 2,000$. c. longitudinal median section through ascocarp wall, $\times 950$. d, c. asci. $\times 1.050$. $f, g$. ascospores, $\times 1,150$. All from holotype of $P$. concentrica.

high, $31-37 \mu \mathrm{m}$ wide, composed of 3-4 layers of small, brown-melanized, isodiametric cells (2.6-4.6 $\mu$ m diameter), (9-) 12-17 $\mu \mathrm{m}$ thick near base of papilla, apex of papilla wall cells hyaline, thin-walled surrounding a circular ostiole without periphyses. Pseudoparaphyses $1.0-1.5 \mu \mathrm{m}$ wide, (46-)77-93 $\mu \mathrm{m}$ long (height of the ascocarp cavity), numerous, narrowly cellular, with guttule-like thickenings at septa, without gelatinous coating. Asci $55.5-65 x$ 


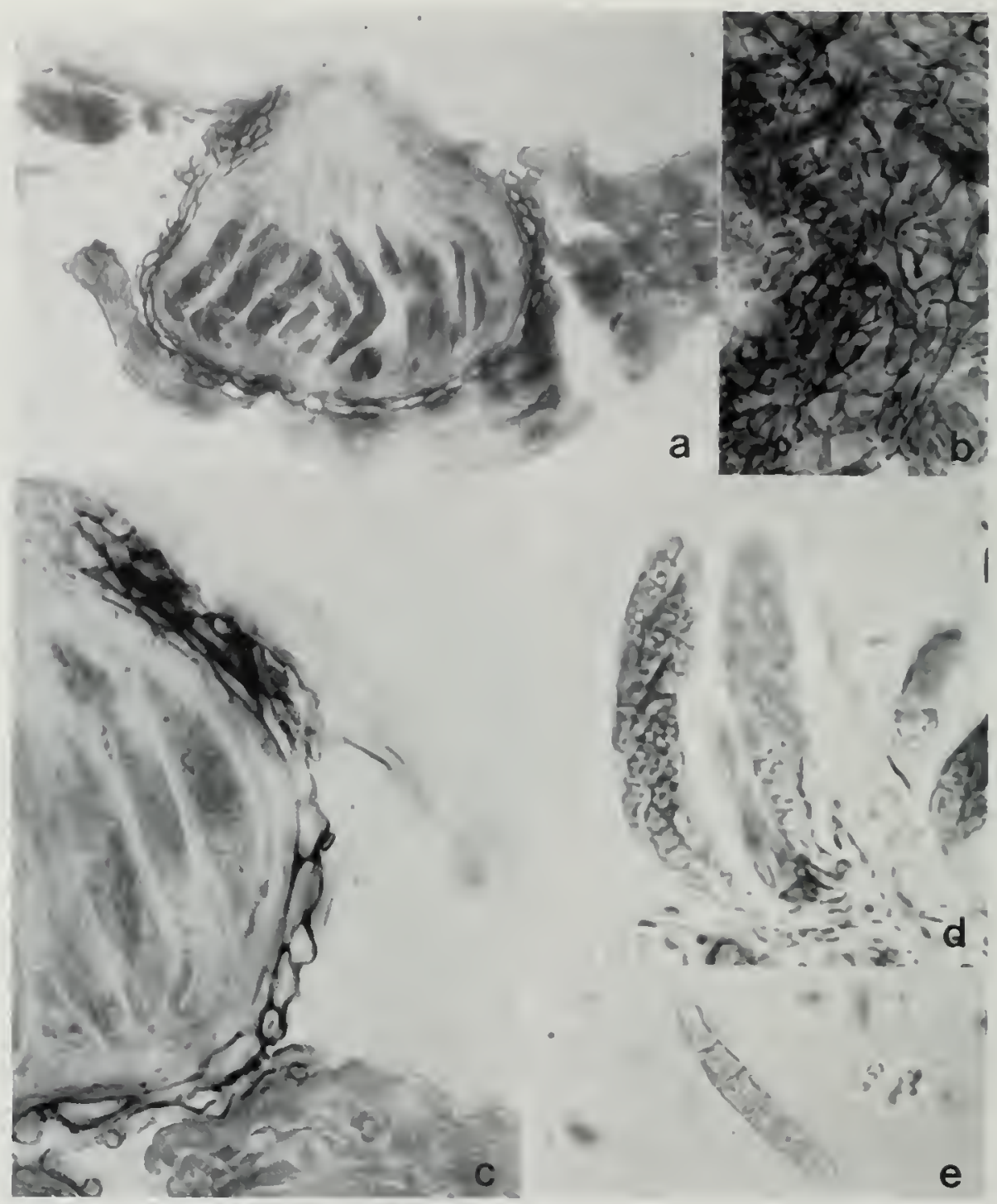

Figure 7. Phaeosphaeria pomona. a. Iongitudinal median section through ascocarp, $x 375$. b. ascocarp wall surface, $x 550$. c. longifudinal median section through ascocarp wall, $x 950$. d. ascus, $x 1.050$. e. ascospore. $\times 1,150$. All from holotype of $P$. pomona.

$8.3-11.5 \mu m$, numerous, basal, cylindrical. thick-walled, short-stalked, rounded apex, with apical chamber, with 8 biseriate ascospores. Ascospores 20.1-26.5 x (2.8-)3.6-5.0 $\mu \mathrm{m}$. narrowly li iform, with acute end cells. second cell from the top occasionally enlarged. straight: 5-sejtate, septa unevenly distributed. without constrictions, order of septation unknown, pale brownish yellow. guttules present in ascospore cells, smooth, thin cellular sheath entirely surrounding spore $(0.7-2.0 \mu \mathrm{m}$ thick).
Holotype: Italy: In pag. super, folior. Pri Mali, socia lermicularia Pomona, a selval (Treviso), Sept. 1875, raro (PAD).

Comments: See under Phacosphaeria lucilla.

- Placosphaeria lucilla (P.A. Saccardo) S.M. Hulndorf comb. nov. See Figure \&. $\equiv$ Leprosplateria lucilla P.A. Saccardo. Nuovo Giomale Botanico ltaliano e Bolletino della Società Botanica Italiana 7:310-311. 1875. (Basionym). 


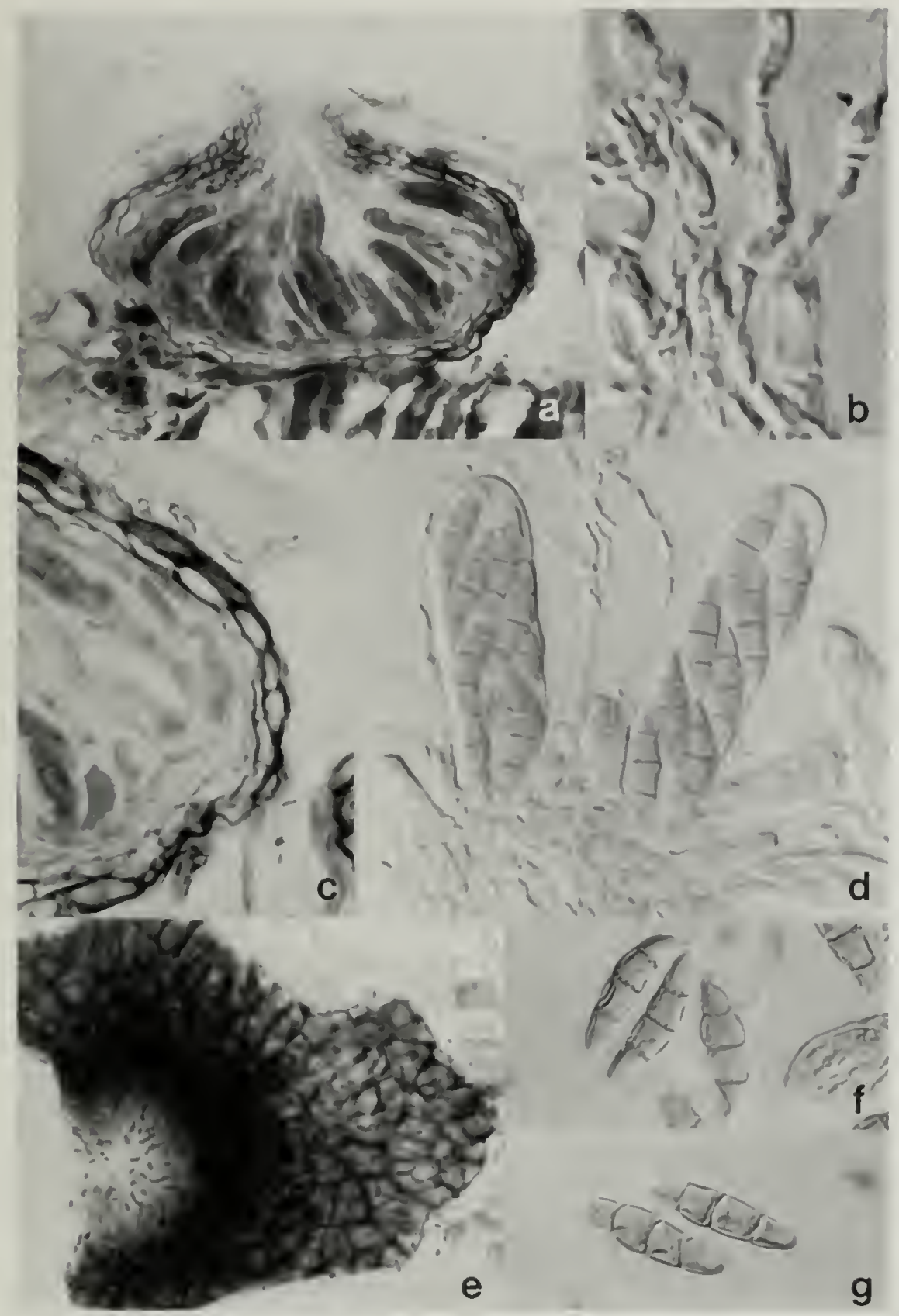

Figure 8. Phaeosphaeria lucilla. a. Iongitudinal median section through ascocarp, $\times 375$. b. cellular pseudoparaphyses, $\times 2,000$. c. longitudinal median section through ascocarp wall, $\times 950$. d. asci, $\times 1,050$. c. ascocarp wall surface, $\times 550 . \mathrm{f}$, g. ascospores, $x \mathrm{I}, 150$. All from holotype ol $P$. Iucilla.

Ascocarps scattered, sparse, immersedsubcuticular, papillate, glabrous, depressedglobose, $110-130 \mu \mathrm{m}$ diameter, $90-115 \mu \mathrm{m}$ high. Ascocarp wall of textura angularis in surface view; in longitudinal section uniformly $6.0-7.7 \mu \mathrm{m}$ thick, composed of 3-4 layers of brown-melanized, compressed, isodiametric-toelongate, pseudoparenchymatous cells (2.3-3.8 $\times 6.9-10.0 \mu \mathrm{m})$. Papilla very short, erumpent, conical, 20-25 $\mu \mathrm{m}$ high, $30-40 \mu \mathrm{m}$ wide, conposed of 4-5 layers of brown-melanized, isodiametric cells (3.0-4.6 $\mu \mathrm{m}$ diameter $), 10.7-$ 
Hn thick near base of papilla. apex of papilla wall cells hyaline, thin-walled surrounding a circular ostiole without periphyses. Pseudoparaphyses $1.5-2.0 \mu \mathrm{m}$ wide, 62-71 $\mu \mathrm{m}$ long (height of the ascocarp cavity), numerous, narrowly cellular, without gelatinous coating. Asci $40-51(-56) \times 8.4-10(-11.5)$ $\mu \mathrm{m}$. numerous, basal, in a broad hymenium. cylindrical, thin-walled, sessile, rounded apex, with 8 bi- to triseriate ascospores. Ascospores $15.3-18.4(-20) \times 3.0-4.6 \mu \mathrm{m}$, fusiform, with acute end cells, second cell from apex slightly enlarged, straight to slightly curved; 3 -septate. septa evenly distributed, order of septation 2:1:2, primary septum median and slightly constricted; pale yellowish brown, wall smooth. without sheath or appendages.

Holotype: Italy: In foliis languidis $P y r i$ communis in agro Tarvisino et Patavino (PAD).

Comments: Fungi in the genus Phaeosphaeria are characterized by immersed ascocarps with thin walls of pseudoparenchyma, fusiform 3- to multiseptate ascospores and monocotyledonous hosts. Nonetheless, Leuchtmann's (1984) treatment of Phaeosphucria includes a group of species found on the leaves and stems of plants in the dicot family Caryophyllaceae. The placement of dicotyledonous Leptosphacria species, morphologically similar to Phaeosphacria, into the genus Phacosphaeria is contrary to Shoemaker and Babcock's ( $1989 \mathrm{~b}$ ) concept of the genus. These authors do not, however, suggest an alternative genus for these species. They do place certain species on dicots in Leptosphacria. citing the presence of thick-walled cells in the ascocarp wall. Phacosphacria pomona and $P$. lucilla are morphologically similar to species of Phaeosphacria found on monocot hosts. They do not have the ascocarp and wall characterislics of Leptosphaeria.

When $P$. pomonc and $P$. lucilla were described, Siccardo $(1875,1876)$ placed them in Leptospharia subgenus Leptosphaerella Sacc., which included fungi from leaves of dicotyledonous plants. Leptosphacria subgenus Leptosphacerella was subsecuently placed in synonymy with Phacosphaeria (Leuchtmann 1984). At this time. there is no other genus suitable for the placement of these "dicot
Phaeosphaeria" species. Erecting a new genus for these species based solely on substrate preference, with no morphological differences from Phaeosphaeria seems unwise. With proof of strict substrate preference requiring experimental evidence, there seems to be some justification for their placement within Phaeosphaeria until such work is done.

-Phoeosphaeria thomasiana (P.A. Saccardo \& C. Roumeguère) S.M. Huhndorf comb. nov. See Figure 9.

\section{三Leptosphaeria thomasiana P.A.}

Saccardo \& C. Roumeguère, Revue Mycologique 5:236. 1883. (Basionym).

Ascocarps scattered, numerous, immersedsubcuticular. globose. flattened at base. papillate, glabrous, 150-175 $\mu \mathrm{m}$ diameter, 110-125 $\mu \mathrm{m}$ high. Ascocarp wall of textura angularis-globulosa in surface view; in longitudinal section uniformly 9.3-12.2 $\mu \mathrm{m}$ thick. composed of 4-5 layers of polygonal. pseudoparenchymatous cells, outer 2-3 layers of polygonal-to-elongate, brown-melanized cells $(2.2-5.0 \times 6.5-8.6 \mu \mathrm{m})$, inner 1-2 layers of elongate-compressed, hyaline cells $(0.7-1.5 x$ 8.0-10.8 $\mu \mathrm{m})$. Papilla very short. erumpent. bluntly conical, 12-30 $\mu \mathrm{m}$ high. 10-36 $\mu \mathrm{m}$ wide, composed of 7-8 layers of small, brownmelanized. isodiametric cells $(2.6-4.6 \mu \mathrm{m}$ diameter), 14-18 $\mu \mathrm{m}$ thick near base of papilla. apex of papilla wall cells hyaline, thin-walled surrounding a 12-18 $\mu \mathrm{m}$ wide circular ostiole without periphyses. Pseudoparaphyses $1.0-$ $1.5 \mu \mathrm{m}$ wide. $80-85 \mu \mathrm{m}$ long (height of the ascocarp cavity). numerous, narrowly cellular. without gelatinous coating. Asci 55.5-65.5x $8.0-10.8 \mu \mathrm{m}$. numerous, basal. cylindricalclavate, thick-walled, short-stalked, rounded apex, with apical chamber, with 8 biseriate ascospores. Ascospores 15.0-18 $8.3 .6-4.5 \mathrm{~m}$. fusiform, with acute end cells, straight or slightly curved: 3 -septate. septa evenly distributed. order of septation 2:1:2, primary septum median, without constrictions: sublyyaline to pale brownish yellow, guttules absent in ascospore cells, smooth, without sheath or appendages.

Holotype: Fraxce: In samentis Rubi emortuis (305-Reliquiae Libertianae) n.v. 

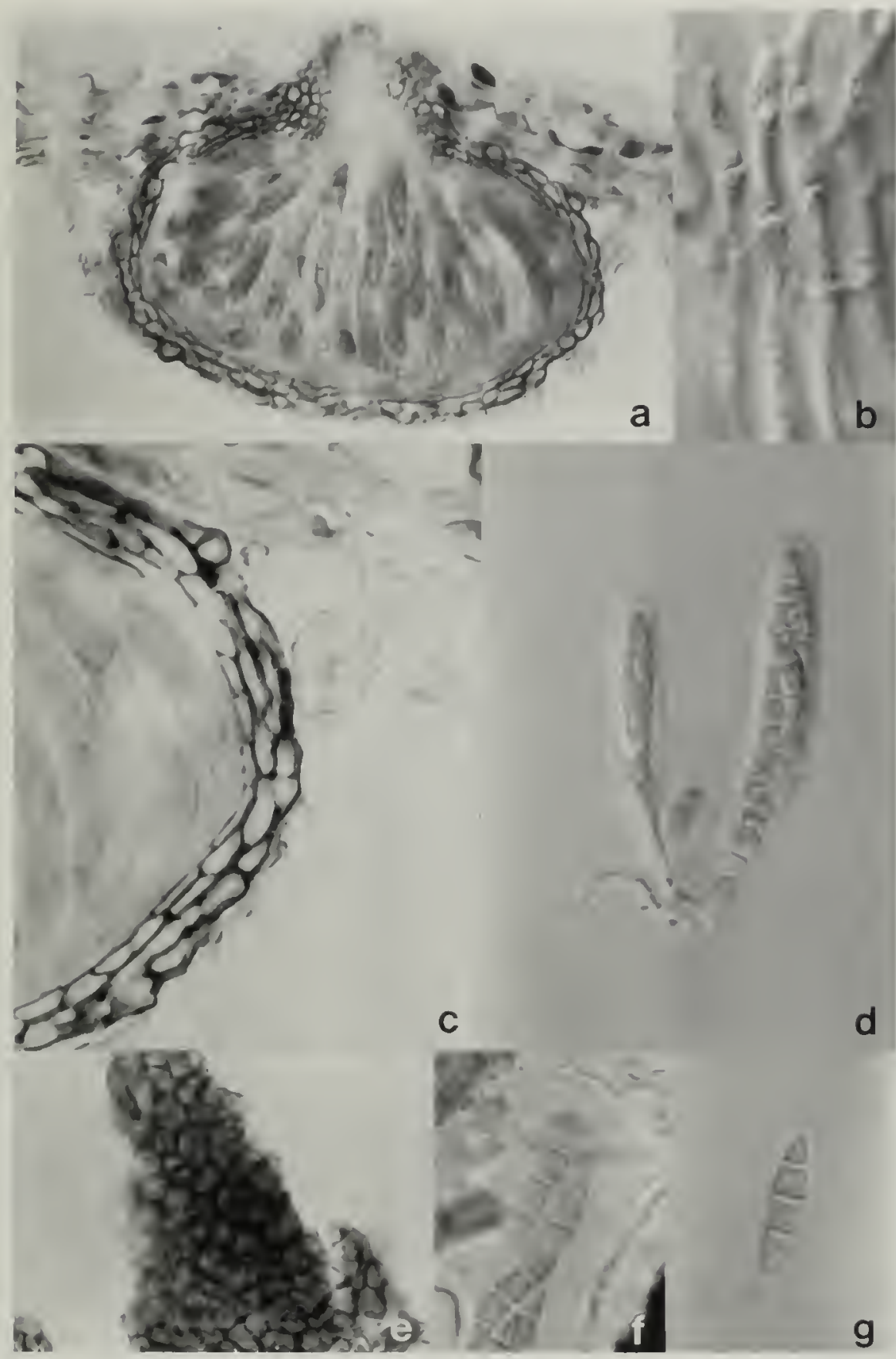

Figure 9. Phaeosphaeria thomasiana. a. longitudinal median section through ascocarp, $\times 375$. b. cellular pseudoparaphyses, $\times 2,000$. c. longitudinal median section through ascocarp wall, $\times 950$. $d$. asci, $\times 1,050$. e. ascocarp wall surface, $\times 550$. f, g. ascospores, x1,150. All from Roum. F. sel cxs. 6039. 
Lxshatae: France: Bois des Roches (Noidan). May 1891. F. Fautrey, Roumeguère, F. sel exs. $6039(\mathrm{NY})$

Other material examined: UNITEd STATES: OrFGON: Corvallis, on loganberry (Rubus loganobaccus Bailey), Mar. 12, 1930. S.M. Zeller; on loganberry, Mar. 15, 1916, A. Frank (all NY).

Comments: Leprosphacria thomasiana is placed in Phacosphaeria because of its small ascocarps immersed beneath the host cuticle and its ascocarp wall of pseudoparenchymatous cells. I was unable to see the type specimen, which is number 305 in the exsiccatae set Reliquiae Libertianae. This is not a regular exsiccatae set (Pfister 1985), and the set at FH did not contain this specimen. The description and plate herein were prepared from

Roumeguère, F. sel exs. 6039 specimen from NY, which included few ascocarps. I did not find any ascocarps of $P$. thomasiana in the collections from Oregon, but the canes did have large gray patches on them as Zeller (1927) described. He also mentions that a cane blight or "Loganberry gray bark disease" has been ascribed to this organism in western Washington. I have seen no reports from other regions of this organism as a pathogen of Rubus.

-Kalmusia clivensis (M.J. Berkeley \& C.E. Broome) M.E. Barr, Mycotaxon. An International Journal Designed to Expedite Publication of Research on Taxonomy \& Nomenclature of Fungi \& Lichens 29:504. 1987. See Figure 10. ESphaeria (Caulicolae) clivensis M.J. Berkeley \& C.E. Broome. Annals and Magazine of Natural History. Series 2. 9:379. 1852.

$\equiv$ Leprosphaeria clivensis (M.J. Berkeley \& C.E. Broome) P.A. Saccardo. Sylloge Fungorum Omnium Hucusque

Cognitorum Digessit P.A. Saccardo 2:16. 1883.

三Diapleella clivensis (M.J. Berkeley \& C.E. Broome) A. Mlunk, Dansk Botanisk Arkiv 15(2):75. 1953.

= Leprosphueria galiorum P.A. Saccardo var. lapsunae P.A. Saccardo \& P.A. Briard, Revue Mycologique 7:209. 188.5.

= Leprosphareria steirnnematis J.B. Ellis \&

13.M. Everhart. Proceedings of the Academy of Natural Sciences of Philadelphia 1890:

$2.37 .(1890) 1891$.
= Leptosphaeria arunci S.M. Zeller, Mycologia 19:134-135. 1927.

= Leprosphaeria longipedicellara J.H. Miller

\& G. Burton, Mycologia 34:2-3. 1942.

Ascocarps scattered, sparse, immersedsubepidermal. papilla erumpent, at times $w$ ith a surrounding clypeus, glabrous, depressedglobose, 275-400 $\mu \mathrm{m}$ diameter. 175-375 $\mu \mathrm{m}$ high. Ascocarp wall of textura prismatica in surface view; in longitudinal section uniformly 15-20 $\mu \mathrm{m}$ thick, composed of 5-6 layers of parallel, elongate, prismatic, scleroplectenchymatic cells $(0.7-1.5 \times 15-20 \mu \mathrm{m})$, outer $3-4$ cell layers slightly brown-melanized, inner 2-3 layers hyaline: at the base cells are compressed. flattened, hyaline. Papilla conical, shortintermediate. (50-)90-100(-130) $\mu \mathrm{m}$ high, 40$80 \mu \mathrm{m}$ wide at the apex, $50-100 \mu \mathrm{m}$ wide at the base, composed of $6-8$ layers of small, lightbrown pigmented. isodiametric cells with no external, melanized crust ( $2-5 \mu \mathrm{m}$ diameter). $10-13 \mu \mathrm{m}$ thick. surrounding a circular ostiole 18-20 $\mu \mathrm{m}$ wide, composed of thin-walled. hyaline, compressed cells, without periphyses. Pseudoparaphyses $0.5-1.5 \mu \mathrm{m}$ wide. 200-225 $\mu \mathrm{m}$ long (height of the ascocarp cavity). numerous, narrowly cellular, without gelatinous coating. Asci $95-110(-150) \times 11-15(-21)$ $\mu \mathrm{m}$, numerous, basal, clavate, thin-walled. long-stalked (27-39 $\mu \mathrm{m}$ long), rounded apex. with 8 biseriate ascospores. Ascospores $19-$ $25(-32) \times 5-8.5(-11) \mu \mathrm{m}$, fusiform, with rounded to acute end cells slightly longer than central cells, straight to slightly curved: 3 septate, septa slightly unevenly distributed. order of septation 2:1:2, with slight constrictions at all septa: dark brown. smooth, without sheath or appendages.

Holotype: Great Britals: King's Cliffe. on dead stems of Pastinaca sativa. Jul 1850 . Herb. Berk. $1879(\mathrm{~K})$.

Exsiccatae: CA\ADA: London, on Steironema ciliarum, as Leprosphaeria steirnnemaris, May 1890. Ell. \& Ev.. North American Fungi 2615 (NY): Sphaer. Brit. Ill 60. (FH).

Other material examined: CASADA: London, on Steironema cilianum. May I\$90. with 1640.

Dearness (Holotype of Leptosphueria steir(mematis. NY): 1640. London. as Leprosphaeria speirnmematis, 19 Apr.. 1890 

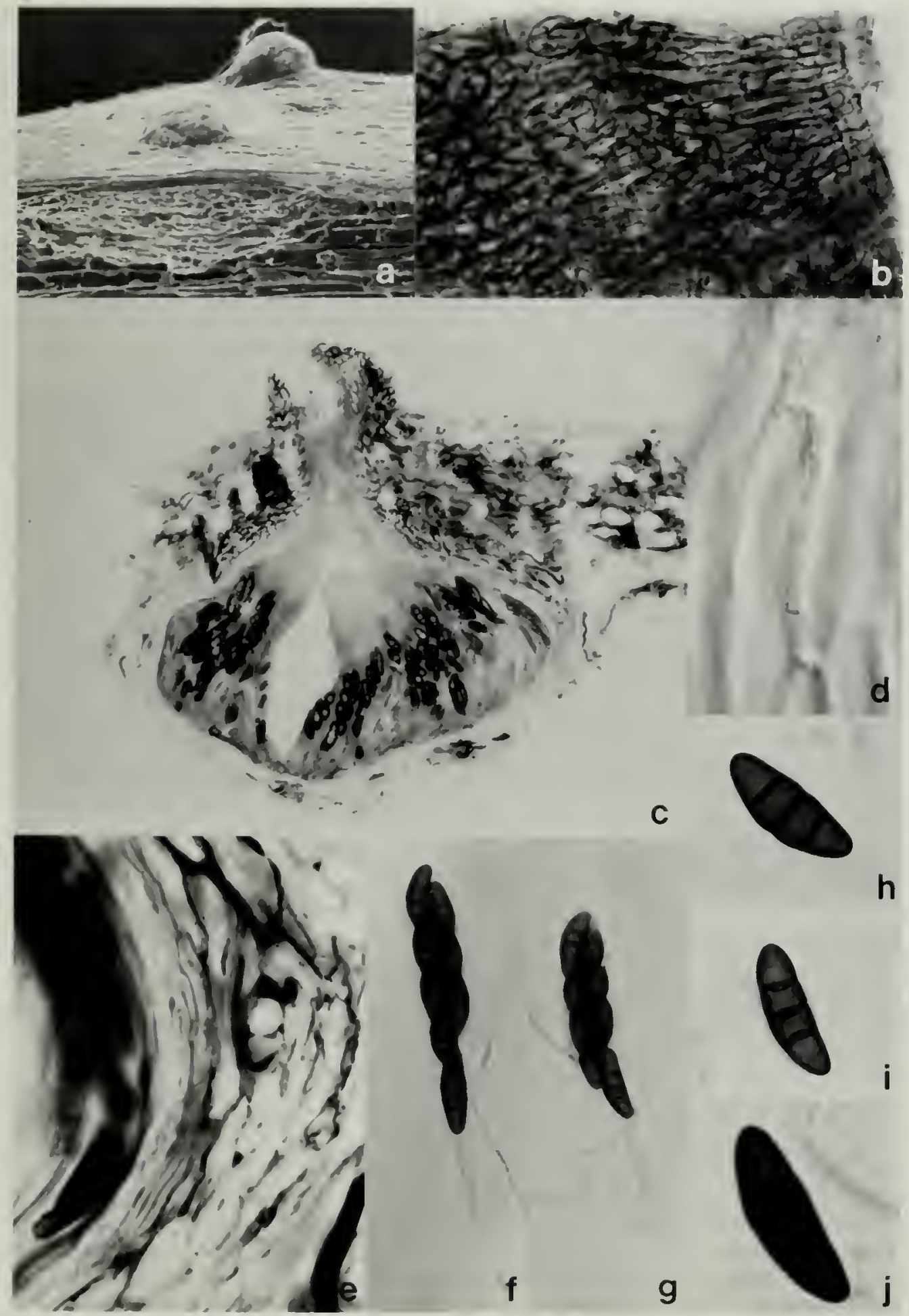

C

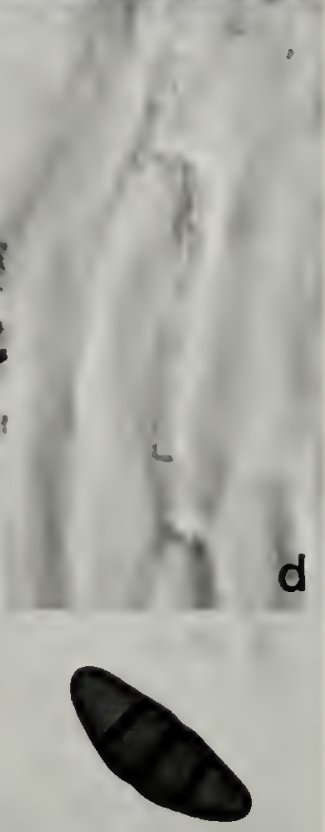

Figure 10. Kalmusia clivensis. a. SEM of immersed ascocarps with erumpent papilla, $x 100$. b. ascocarp wall surface, $\times 550$. c. longitudinal median section through ascocarp, $x 125$. d. cellular pseudoparaphyses, $x 2,000$. c. longitudinal median section through ascocarp wall, $x 950$. f, g. asci, $\times 525$. $h-j$. ascospores, $x 1,150$. a, c, $d$. $\mathrm{e}, \mathrm{f}$, and $\mathrm{h}$ from holotype of Leptosphaeria arunci; $\mathrm{b}, \mathrm{g}$. and $\mathrm{i}$ from holotype of $K$. clivensis: $\mathrm{j}$ from lectotype of $L$. longipedicellata. 
Ny. Grfat Britain: England, Chute Meadow. Lambriggan, W. Cornwall, on Centaurea nigra, May 9, 1942, F. Rilstone (NY-MEBB coll); Scotland, Wester Ross, Rassal N.N. Reserve. on? Senecio jacoboed, June 2, 1982, P.F. Cannon (NY). ITALY: Briard no. 8, on Lapsama communis, June 12, 1885 (holotype of Leptosphacria galiorum var. lapsanae, PAD). United States: Colorado: Larimer Co., $3 \mathrm{mi}$ W. Redfeather Lakes, $8100^{\prime}$ Roosevelt National Forest, on Rosa sp.. Aug. 4, 1984, MEBB \# 7008 (NY); Georgia: 7684, Clarke Co.. Athens, South Campus, University of Georgia, on Daucus carota, Sept. 1 1, 1939, J.H. Miller (Lectotype of Leptosphaeria longipedicellata, GAM): Michigan: Emmet Co., Gill and Elder Roads. Carp Lake, on ? Acer, Sept. 11, 1969. MEBB \#5527 (NY): OREGoN: Multnomah Falls, April, on dead stems of Aruncus silvester (holotype of Leptosphaeria armaci in Zeller Herb. 6811, NY).

Comments: Four of the putative Leptosphaeria species that were examined are synonymous with Kalmusia clivensis; one was found on a Rosaceous host (L. arunci on Aruncus). The most distinctive feature of this species is the presence of long-stipitate asci with prominent dark brown, 3-septate ascospores. The long stipe, as well as the thin ascus wall, has led previous workers to treat it as a unitunicate fungus in the monotypic genus Diapleella (Munk 1957, Dennis 1978). Shoemaker (1984a) retained the genus Diaple ella but treated it as bitunicate. Barr (1987b) transferred $D$. chivensis to the genus Kalmusia Niessl without much explanation. The original description of Kaimusia (Niess! 1871) and the illustration of the genus in Berlese (1890) show a fungus with long-stipitate asci and dark brown, 3-scptate ascospores. Kalmusia clivensis appears to be well-placed within this genus.

Shoemaker (1984a) looked at one collection of Leptosphaeria longipedicellata on Solidago caesia L., which is cited in the original description of the species. He mentions that "the original description of $L$. lomgipedicellata is strongly suggestive of Diapleella clivensis." This collection was in fact $L$. macrospora (Fuckel) Thümen, and Shoemaker did not resolve the placement of $L$. lomgipedicellata. The collection on Daurus carota $\mathrm{l}$.., cited in the description and marked as type on the herbarium packet, matches the original description exactly and is the same as Kalmusia clivensis except that the ascospores and asci are slightly larger than those in the type collection of $K$. clivensis. The ascocarp and wall in section appear exactly the same. 1 believe the size differences are probably due to environmental differences or other individual variation and that $L$. longipedicellata is synonymous with $K$. clivensis. Collection 7684, Clarke Co., Athens, South Campus. University of Georgia. on Daucus carota. Sept. 11. 1939. J.H. Miller (GAM) is chosen as the lectotype of Leptosphaeria longipedicellata.

\section{- Kalmusia coniothyrium (L. Fuckel) S.M.} Huhndorf comb. nov. See Figure 11. $\equiv$ Sphaeria coniothyrium L. Fuckel, Symbolae Mycologicae, p. 115. 1870. (Basionym). $\equiv$ Leptosphaeria coniothyrium (L. Fuckel) P.A. Saccardo, Nuovo Giomale Botanico Italiano e Bolletino della Società Botanica Italiana 7:317. 1875. DMelanomma coniothyrium (L. Fuckel) L. Holm, Symbolae Botanicae Upsalienses 14(3):56-57. 1957. $\equiv$ Diapleella coniothyrium (L. Fuckel) M.E. Barr in M.E. Barr, C.T. Rogerson, S.J. Smith, and J.H. Haines, Bulletin of the New York State Museum 459:30. 1986.

= Sphaeria (Ohtectae) hendersonia J.B. Ellis in M.C. Cooke and J.B. Ellis, Grevillea 6:14-15. 1877. EClypeosphaeria hendersoniae (J.B. Ellis) P.A. Saccardo, Sylloge Fungorum Omnium Hucusque Cognitorum Digessit P.A. Saccardo 2:91. 1883. ELeptosphacria (Clypeosphacria) hendersoniae (J.B. Ellis) M.C. Cooke. Grevillea 17:91. 1\$89.

Ascocarps clustered, numerous, inmersedsubepidermal. depressed. globose, flattened at top and base. sometimes beneath blackened clypei, papillate, glabrous, 175-300 $\mu$ m diameter, 175-200 $\mu \mathrm{m}$ high. Ascocarp wall of textura angularis-globulosa in surface view; in longitudinal section $15-25 \mu \mathrm{m}$ thick at the sides, $13-18 \mu \mathrm{m}$ at the base, composed of $\delta-12$ layers of polygonal, pseudoparenchymatous cells, outer 3-5 layers of isodiametric-toslightly-elongate, light brown cells $(5.0-9.5 x$ 


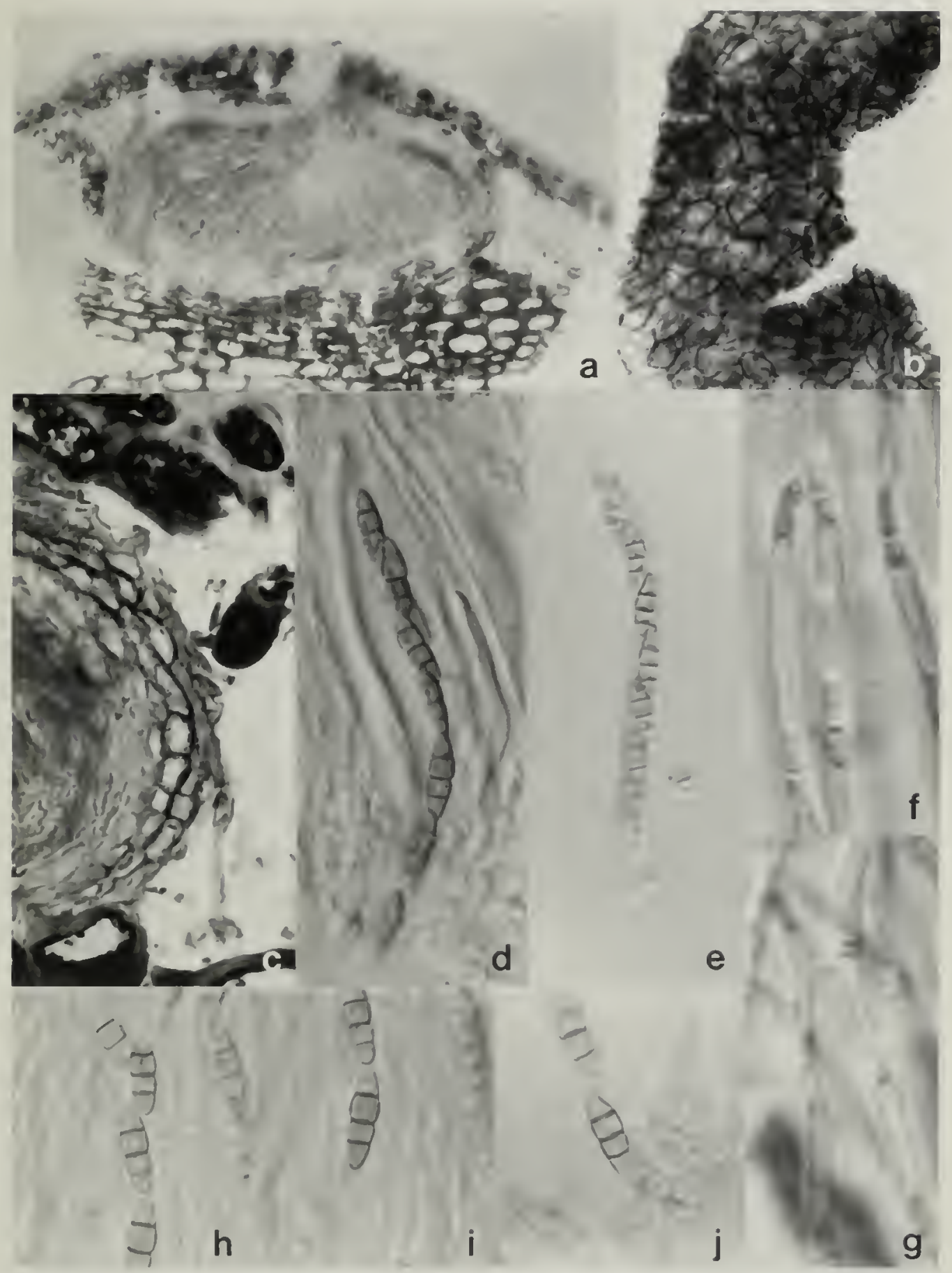

Figure 11. Kalmusia coniothyrium. a. Iongitudinal median section through ascocarp, $\times 250$. b. ascocarp wall surface, $\times 550$. c. longitudinal median section through ascocarp wall, $x 950$. d. c. asci, $\times 1,050$. f. g. cellular pseudoparaphyses, $\times 2.000$. $\mathrm{h}-\mathrm{j}$. ascospores, $\times 1,150$. a-d. f-i from holotype of $K$. coniothyrium; $\mathrm{e}, \mathrm{j}$ from neotype of Sphaeria hendersonia. 
(1)-5.0 $\mathrm{\mu m}$ ), inner 5-7 layers of small, isodiametric-elongate, compressed, hyaline cells $(3.6-4.3 \times 2.0-3.6 \mu \mathrm{m})$. Papilla short, erumpent. bluntly conical, $45-55 \mu \mathrm{m}$ high, 25$35 \mu \mathrm{m}$ wide, $16-18 \mu \mathrm{m}$ thick, composed of 510 layers of small, hyaline, isodiametric cells (1.4-2.8 $\mu \mathrm{m}$ diameter), surrounding a 10-20 $\mu \mathrm{m}$ wide, circular ostiole without periphyses. Pseudoparaphyses $1.0-1.5 \mu \mathrm{m}$ wide, $75-100$ $\mu \mathrm{m}$ long (height of the ascocarp cavity). numerous, narrowly cellular, with guttule-like thickenings at septa, with gelatinous coating. Asci $60-75 \times 5.5-7.5 \mu \mathrm{m}$, numerous, basal in a broad hymenium, cylindrical, thin-walled, short-stalked, rounded apex, with apical chamber, with 8 overlapping, uniseriate ascospores. Ascospores 11.5-14.4(-15.8) x $3.6-4.5 \mu \mathrm{m}$. fusiform to ellipsoidal, with acute end cells, second cell somewhat enlarged. straight or slightly curved; 3-septate, septa slightly unevenly distributed, order of septation 2:1:2, primary septum median and constricted: brownish yellow, guttules lacking, smooth, without sheath or appendages.

Holotype: Austria: Auf durren Ranken von Rubus fruticosus, selten. im Fruhling. An der Heimbach bei Oestrich $(G)$.

Exsiccatae: Rehm, Asc. 388, on Rubus fruticosus (NY); Krieger, Fungi saxon. 18. 1120, 1121 (NY): Petrak Kryptogamae exsic. 2318 (NY): Sacc, Mycotheca Veneta 72, as Sphaeria fuscella f. Ampelopsidis hederaceae, (FH): Petrak, Fl. Boh. et Mor. exsic. 11 no. 4, as Clypeosphaeria notarisii $(\mathrm{FH})$; Ellis $\mathrm{N}$

American Fungi 581 as Sphaeria Hendersonia. Mar. 1878 (ILL, FH, NY).

Other material examined: CANADA: Ottawa, on Sambucus racemosa, Mar. 10, 1897 (NY); London, as Clypeosphaeria Hendersonia, 1883. 3 May 1892 (NY). ItaLY: 198 as Sphaeria clyperla, de Notaris (RO). United States: DELAWARE: Faulkland, as Sphaeria Hendersonia, Mar. 20, 1887 (NY); NEW JERSEY: Newfield, on Rubus strigosus. J.B. Ellis 101, May 29, 1880 (neotype of Sphaeria Hendersonia. NY); on Rubus occidentalis, as Sphaeria Hendersomia, Aug. 4 1879. Apr. 1880, J.B. Ellis (FH); as Clypeosphaeria Hendersonia. Aug. 15. 1894. J.B. Ellis 773
(NY); Massachlsetts: Andover, as Sphaeria Hendersonia. Rev. J. Blake No. 79 (NY): North Dakota: Kulm, on Rubus strigosus, Mar. 12, 1916, Brenkle, Fungi Dakotenses 384 (NY): OrEgon: Troutdale, Feb. 10, 1929, M.J. O'Connell (NY): Gresham, Apr. 30. 1934, S.M. Zeller (NY); Pexissylvavia: Avestrud Co., on Rubus sp.. July 10, 1944 (NY): Wiscossix: Sauk Co.. Aldo Leopold Reserve, on Rubus sp.. 9 Apr. 1988, 30 Sept. 1988, S.M. Huhndorf (ILLS).

Comments: This fungus is placed in Kalmusia because of its immersed, clypeate ascocarps with pseudoparenchymatous walls composed of compressed cells. Kalmusia coniothyrium lacks the characters distinctive of Leptosphaeria, including erumpent to superficial ascocarps with a wall of scleroplectenchymatous cells. Holm (1957) placed the species in Melanomma, but the fungus does not fit the current concept of that genus (Bars 1987a) because it lacks erumpent ascocarps with walls composed of small thick-walled cells, asci formed peripherally within the centrum, and trabeculate pseudoparaphyses. However, the ascospores of this fungus do strongly resemble those of some Melanomma species. The ascus shape of $K$. coniothyrium differs from that of $K$. clivensis in being cylindrical and short-stalked, and the ascospores are brownish yellow rather than dark reddish brown. But in Kalmusia cbuli Niessl. the type of the genus, these characters are variable: asci are clavate to cylindrical, shortor long-stalked, and ascospores are lighter brown than those of $K$. clivensis. There appears to be sufficient range within the genus to accommodate $K$. coniothyrium.

Sphaeria hendersonia is synonymous with $K$. coniothrimum. The description for the holotype specimen is at NY. but the actual specimen is missing. Because no other specimen is cited in the published description and it is uncertain what was available to Ellis when he described the organism. a neorype was chosen from the Ellis collection at NY which matches the description and is in good condition. The neotype of Sphaeria hendersonia is J.B. Ellis 101. Newfield. New Jersey, on Rubus strigosus. May 29. 1880. 


\section{Lophiostomataceae}

The following species possesses characteristics of the Lophiostomataceae in the order Pleosporales (Barr 1987a). Lophiostomataceae sensu Holm and Holm (1988) is considered a heterogeneous group whose overall common characters, the flattened neck and slotlike ostiole, are highly adaptive and unstable. Consequently, the family in this sense may be completely dissociated (Holm and Holm 1988). Lophiostomataceae sensu Barr (1987a) contains genera that are united by wall characteristics, pseudoparaphysis structure and ascospore morphology. The compressed apical papilla is considered to be of generic or specific importance. Taxa in the Lophiostomataceae may have this type of papilla or may have a conspicuous, rounded apical papilla, or a short papilla with or without grouped setae, or the apex may open by a pore or slit.

- Lophiostoma subcutanea (M.C. Cooke \& J.B. Ellis) S.M. Huhndorf comb. nov. See Figure 12.

ESphaeria (subtectae) subcutanea M.C. Cooke \& J.B. Ellis, Grevillea 7:41. 1878. (Basionym).

$\equiv$ Leptosphaeria subcutanea (M.C.

Cooke \& J.B. Ellis) J.B. Ellis in N.L.

Britton, Catalogue of Plants Found in New Jersey. Geological Survey of New Jersey, Final Report of the State Geologist, 2(1):525. 1889.

EMetasphaeria subcutanea (M.C. Cooke \& J.B. Ellis) P.A. Saccardo, Sylloge Fungorum Omnium Hucusque Cognitorum Digessit P.A. Saccardo 2:167. 1883.

Ascocarps clustered, sparse, superficial, papillate, glabrous, conic, $150-170 \mu \mathrm{m}$ diameter, 180-225 $\mu \mathrm{m}$ high. Ascocarp wall of textura angularis-prismatica in surface view; in longitudinal section (15-)20-23 $\mu \mathrm{m}$ thick at sides and base, composed of 6-7 layers of polygonal, isodiametric-to-elongate, pseudoparenchymatic cells $(2.0-3.6 \times 5-7 \mu \mathrm{m})$, outer 3-4 layers of brown-melanized cells at the sides, inner 1-3 layers of hyaline, compressed cells; basal wall composed only of hyaline. elongate-compressed cclls. Papilla elongate-conical, longitudinally compressed.
75-85 $\mu \mathrm{m}$ high, $55-75 \mu \mathrm{m}$ wide at the apex, $100-125 \mu \mathrm{m}$ wide at the base, composed of 6-7 layers of brown-melanized, thickened, isodiametric cells (2.5-4.0 $\mu \mathrm{m}$ diameter); at apex, cells coalescing to form a thickened dark brown mass; wall 25-27 $\mu \mathrm{m}$ thick, surrounding a $40-$ $50 \mu \mathrm{m}$ wide slotlike ostiole lined with periphyses. Pseudoparaphyses $0.5-1.5 \mu \mathrm{m}$ wide, 108-124 $\mu \mathrm{m}$ long (height of the ascocarp cavity), numerous, narrowly cellular, without gelatinous coating. Asci 77-84(-92) $\times$ 5.3-7.6 $\mu \mathrm{m}$, numerous, basal, cylindrical, thin-walled, short-stalked, rounded apex, with 8 biseriate ascospores. Ascospores (20-)25-29 × 3.0-3.5 $\mu \mathrm{m}$, narrowly fusiform, with acuminate end cells, second cell slightly enlarged, straight to slightly curved; 4-6(-8)-septate, septa unevenly distributed, order of septation unknown, with slight constrictions at all septa; hyaline to subhyaline, guttules present in ascospore cells, wall smooth, possibly with thin cellular sheath surrounding entire spore, without appendages.

Holotype: UnITED STATES: On decorticated limbs of Pyrus communis L (NY, K).

Comments: Holm and Holm (1988) considered the Swedish species of the Lophiostomataceae and emphasized ascocarp shape and peridial anatomy in distinguishing the genera Lophiostoma Ces. \& de Not. and Lophiotrema Sacc. emend. L. Holm \& K. Holm. The presence of a flattened papilla or neck and a slotlike ostiole have been used to distinguish the Lophiostomataceae from other groups. Although these features are highly variable in some species, they are still useful for placing this species in the Lophiostomataceae. However, generic placement within the family is problematic. The conic or pyriform ascocarp shape with a distinct flattened neck and the fusiform ascospores that are multiseptate within the ascus suggest Lophiostoma. The cylindric asci suggest Lophiotrema. The ascocarp wall anatomy in section resembles that of Lophiotrema, with uniformly thick walls of polygonal globose or angular cells. But in surface view, the cells seem to form a textura prismatica suggesting the long, parallel cells of Lophiostoma. The fungus is placed in Lophiostoma with some reservation because, at this time. there is no other suitable place for it. 


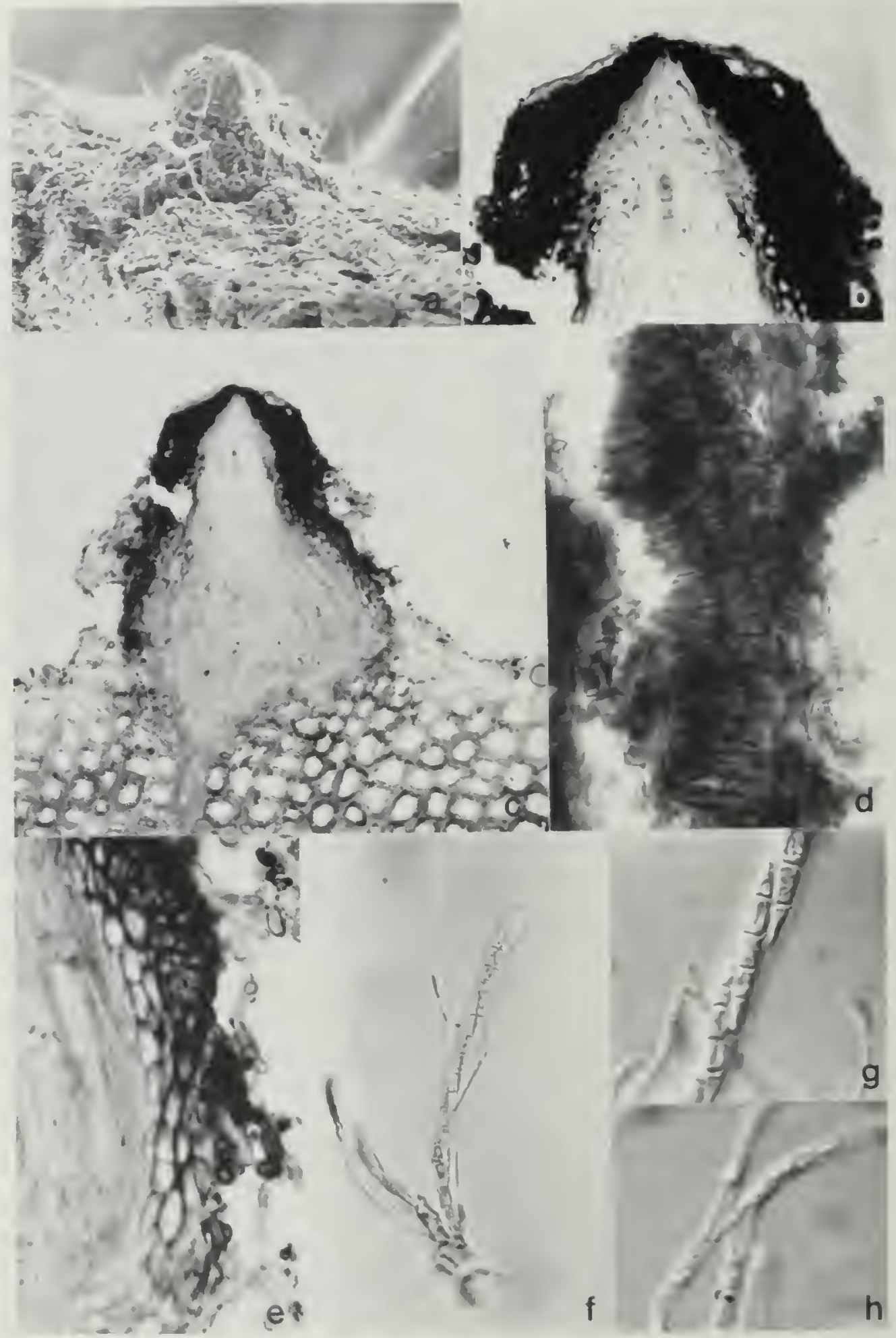

Figure 12. Lophiosema subcuroned. a. SEM of ascocarp with apical crest. $\times 175$. b. Iongitudinal section of alsocarp neck with periphyses, x 525. c. Iongitudinal median section through ascocarp, $x 325$. d. ascocarp fall sublace, $x 550$. e. longitudinal median section through ascocarp wall, $x 950$. f. ascus, 5925 . g. ascospores

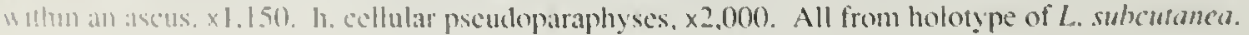




\section{Leptosphaeria Species Referable to the Melanommatales}

One species investigated had characteristics of the Melanommataceae in the order Melanommatales (Barr 1987a). The order

Melanommatales is distinguished from the Pleosporales by trabeculate pseudoparaphyses, asci arranged peripherally within the centrum. an ascocarp wall composed of small or compressed cells, and ascospores with bipolar symmetry. Any one of these features may deviate in a particular taxon. Fungi in the Melanommataceae are distinguished by gregarious, erumpent ascocarps with a wall of small, thick-walled cells.

- Melanomma puhis-pyrius (C.H. Persoon:E.M. Fries) L. Fuckel, Symbolae Mycologicae p.

159, 1870. See Figure 13. इSphaeria pulvis-pyrius C.H. Persoon, Synopsis Methodica Fungorum p. 86, 1801 ; E.M. Fries, Systema Mycologicum Sistens Fungorum 2:458. 1823.

= Cladosphaeria rimicola G.H. Otth, Mitteilungen der Naturforschenden Gesellschaft in Bern 1870:106. 1871. Nom inval. Art. 43.1. [The genus Cladosphaeria was validated in 1894.]

$\equiv$ Leptosphaeria rimicola (G.H. Otth)

P.A. Saccardo, Hedwigia, Dresden

35:XXIX. 1896; Sylloge Fungorum

Omnium Hucusque Cognitorum Digessit P.A. Saccardo 1]:XXIX. 1896.

Ascocarps clustered, sparse, superficial, papillate, glabrous with tomentum of thickwalled brown hyphae surrounding and between ascocarps, conic-subglobose to irregular, 425$550 \mu \mathrm{m}$ diameter, 475-600 $\mu \mathrm{m}$ high. Ascocarp wall of textura angularis-epidermoidea in surface view; in longitudinal section $55-75 \mu \mathrm{m}$ thick at sides, $80-100 \mu \mathrm{m}$ thick at hase, composed of 21-35 layers of cells, outer $5-6$ layers of polygonal, isodiametric, brownmelanized, scleroplectenchymatic cells (3.6$4.3 \times 7-8 \mu \mathrm{m})$ giving rise to the thick-walled hyphae of the tomentum, middle 6-9 layers composed of hyaline, polygonal-elongate, scleroplectenchymatic cells $(5-7 \times 10-12 \mu \mathrm{m})$, inner 10-20 layers of small, polygonal, thickwalled, hyaline cells (2.0-5.7 $\mu \mathrm{m}$ diameter), which become compressed and obscured toward the interior of the cavity. Papilla broadly rounded to dome-shaped, 110-160 $\mu \mathrm{m}$ high, 160-250 $\mu \mathrm{m}$ wide at the apex, 220-300 $\mu \mathrm{m}$ wide at the base; wall $36-54 \mu \mathrm{m}$ thick, composed of 12-15 layers of cells, outer layers of brown-melanized, thickened, isodiametric cells (3.6-5.7 $\mu \mathrm{m}$ diameter), inner layers hyaline, compressed, sursounding a 75-150 $\mu \mathrm{m}$ wide circular ostiole lined with periphyses.

Pseudoparaphyses $0.5-1.5 \mu \mathrm{m}$ wide, 250-375 $\mu \mathrm{m}$ long (height of the ascocarp cavity), numerous, trabeculate with sparse branching, with guttule-like thickenings at septa, without gelatinous coating. Asci (95-)120-150 × 8.5$12 \mu \mathrm{m}$, numerous, basal and lateral, partially lining the peripheral wall of the centrum, cylindrical, thin-walled, short-stalked, rounded apex, with 8 overlapping uniseriate ascospores. Ascospores 17.2-22.3 x 5.7-8.0 $\mu \mathrm{m}$. fusiform. with acute end cells, straight to slightly curved: 3 -septate, septa evenly distributed. order of septation 2:1:2, primary septum median and slightly constricted, bipolarly asymmetrical with a wider anterior and a narrower posterior part, second cell slightly enlarged; pale brown occasionally with slightly lighter colored end cells, wall smooth, without sheath or appendages.

Exsiccatae: Czechoslovakia: Betschwa-Ufer, Dec. 27, 1911, M. Weisskirchen, Petrik, Fl. Boh et Mor. exsic. Lfg. 4 Nr. 196 (FH): FINLAND: Bjork, Dec. 9. 1865. Karsten. Fungi Fenniae 992 (F11); Finland: on Sambucus racemosa, Jan. 1866, Karsten, Fungi Fenniae 995 (FH). 

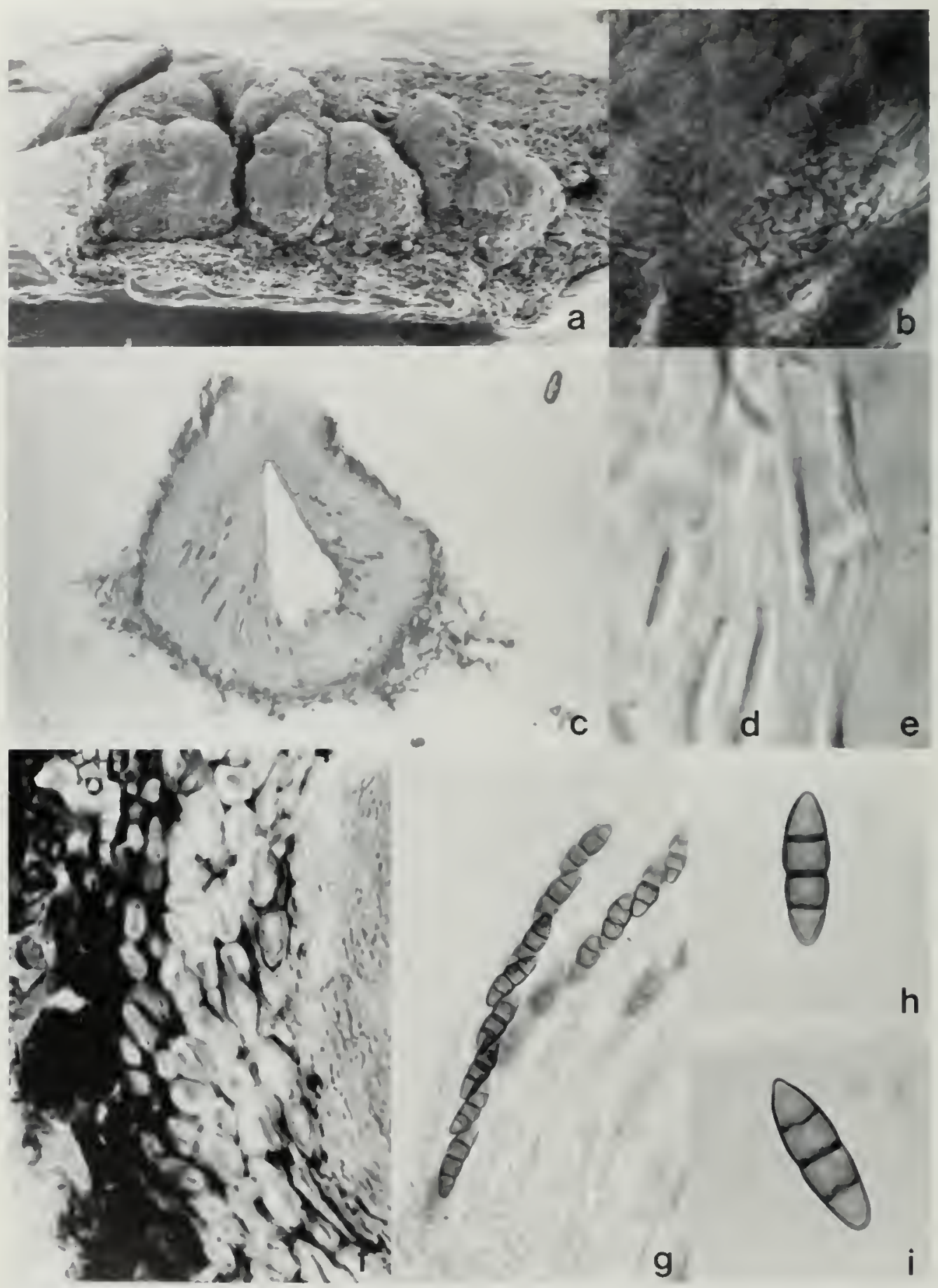

Figure 13. Mclanomma pulvis-pyrius. a. SEM of erumpen ascocarps, $\times 35$. b. ascocarp wall surface, $\times 550$, c. longitudinal median section through ascocarp, $\times 75$. d, e. trabeculate pseudoparaphy ses, $x 2,000$.

f. longitudinal median section through ascocarp wall. $\times 950$. g. ascus, $\times 525$. h. i ascospores, $\times 1.150$. All irom holotype of Cladesphacria rimicolds. 
Other material examined: SwITZERLAND:

Bremengartenwald, on Prunus avium L.

(holotype of Cladosphaeria rimicola. BERN).

United States: California: Spruce Cove

Heads, Trinidad, Humbolt Co.. on Rubus

parviflorzıs, 30 Jan. 1941. H.E. Parks 6513

(FH).

Comments: Leptosphaeria rimicola, described from the fallen branches of Prumus avium L., is synonymous with Melanomma pulvis-pyrius.

Leptosphaeria rimicola has the overall appearance of $M$. pulvis-pyrius, with large, gregarious, superficial ascocarps and ascospores with the characteristic Melanomma shape: 3-septate with the primary median septum dividing the spore into a wider anterior and a narrower posterior part. The measurements of the ascospores of $L$. rimicola are somewhat larger than were found by Chesters (1938) for $M$. pulvis-pyrius, but they are not beyond the range for $M$. pulvis-pyrius given by Saccardo (1878). The asci peripherally lining the centrum about halfway up the wall and the ascocarp wall composed of small thickened cells correspond to Barr's (1987a) concept of the genus

Melanomma. The pseudoparaphyses are thin and flexuous, but the branchings and anastomoses are infrequent and the septa often show thickenings, making them difficult to accurately identify as trabeculate. 


\section{Leptosphaeria Species Referable to the Dothideales}

The species in this chapter all belong in the Dothideales (sensu Barr 1987a). Barr's concept of this order differs considerably from the all-inclusive concept of von Arx and Müller (1975) or the broad concept of Eriksson and Hawksworth $(1985,1986)$. The Dothideales (Barr 1987a) are characterized by ascocarps without a hamathecium (although interthecial cells are often present) and by asci that tend to be ovoid to saccate, arranged in a basal fascicle or a basal layer. The families represented are the Dothioraceae and the Pseudosphaeriaceae.

\section{Dothioraceae}

- Saccothecium sepincola (E.M. Fries:E.M. Fries) E.M. Fries, Summa Vegetabilium Scandinaviae, p. 398. 1849. See Figure 14. ESphaeria sepincola E.M. Fries.

Observationes Mycologicae. 1:181. 1815; Systema Mycologicum Sistens Fungorum 2:498. 1823. [As saepincola.] $\equiv$ Metasphaeria sepincola (E.M. Fries: E.M. Fries) P.A. Saccardo, Sylloge Fungorum Omnium Hucusque Cognitorum Digessit P.A. Saccardo 2:164. 1883. [As Fr? Fuckel.] ELeptosphaeria sepincola (E.M. Fries:E.M. Fries) H.G. Winter, Dr. L. Rabenhorst's Kryptogaman-Flora von Deutschland, Oesterreicin und der Schweiz, Second edition, 1(2):473. 1885. ESphacrulina sepincola (E.M. Fries: E.M. Fries) K. Starbäck, Botaniska Notiser 1890:117. 1890; Botanisches Zentralblatt, 46:261. 1891. EPringsheinia sepincola (E.M. Fries: E.M. Fries) F. v. Höhncl. Annales Mycologici 18:97. 1920.

EPleosphaerulina sepincola (E.M. Fries: E.M. Fries) 11. Relım in F. v. Hölnnel. Annales Mycologici I8:96. 1920. ESclerodothis sepincola (E.N1. Fries:
E.M. Fries) F. Petrak. Annales

Mycologici 19:41. 1921.

For other synonyms see Barr (1972).

Ascocarps thickly scattered. immersedsubepidermal, globose, glabrous, 180-200 $\mu \mathrm{m}$ diameter, 170-180 $\mu \mathrm{m}$ high. Ascocarp wall of textura angularis in surface view: in longitudinal section 25-36 $\mu \mathrm{m}$ thick at sides and base. up to $45 \mu \mathrm{m}$ thick at apex, composed of 7-8 layers of pseudoparenchymatic. polygonal cells $(5-6 \times 6-12 \mu \mathrm{m})$, outer $2-3$ layers of isodiametric-to-elongate. brown-melanized cells, inner 4-5 layers of hyaline-subhyaline, thin-walled, elongate-compressed cells, at the base giving rise to a central column (18-23 $\mu \mathrm{m}$ high, $27-36 \mu \mathrm{m}$ wide) of hyaline, isodiametric cells (3-4 $\mu \mathrm{m}$ diameter, but cell boundaries becoming obscured in mass) on which the asci are borne. Papilla broadly rounded. bluntly conical. 45-55 $\mu \mathrm{m}$ high. 55-70 $\mu \mathrm{m}$ wide. Asci $40-60 \times(13-)] 5-25 \mu \mathrm{m}$. numerous. fasciculate. borne on a basal column, oblong-ovate to clavate, thick-walled, short-stalked. apex rounded and thickened, with 8 bi- to triseriate ascospores. Ascospores (17-) 18.5-20.5(-22.5) $\times 5.0-7.2 \mu \mathrm{m}$, obovate, with acute end cells. broad above and tapering to a narrower base. straight to slightly curved; 4-5(-6)-septate. septa unevenly distributed, septation order 3:2:1:2:4 or $4: 2: 1: 3: 5$, primary septum submedian, vertical septum occasionally present in second or third cell from the top: hyaline, wall smooth. without sheath or appendages.

Lectotype: Swedex: Ad ramos emortuos Rosae alionumque fruticum (UPS).

Exsiccatac: Al'stria: Nassau, on Rosa camina. as Melasphacria sepincola. 1894. Fuckel. Herbier Barbey-Boissier 385 (FH): Nassau, on Ruhus frutionsus, as Sphacenlina imermixa (Berk \& Br) Sacc, 1894. Fuchel. Herbier 


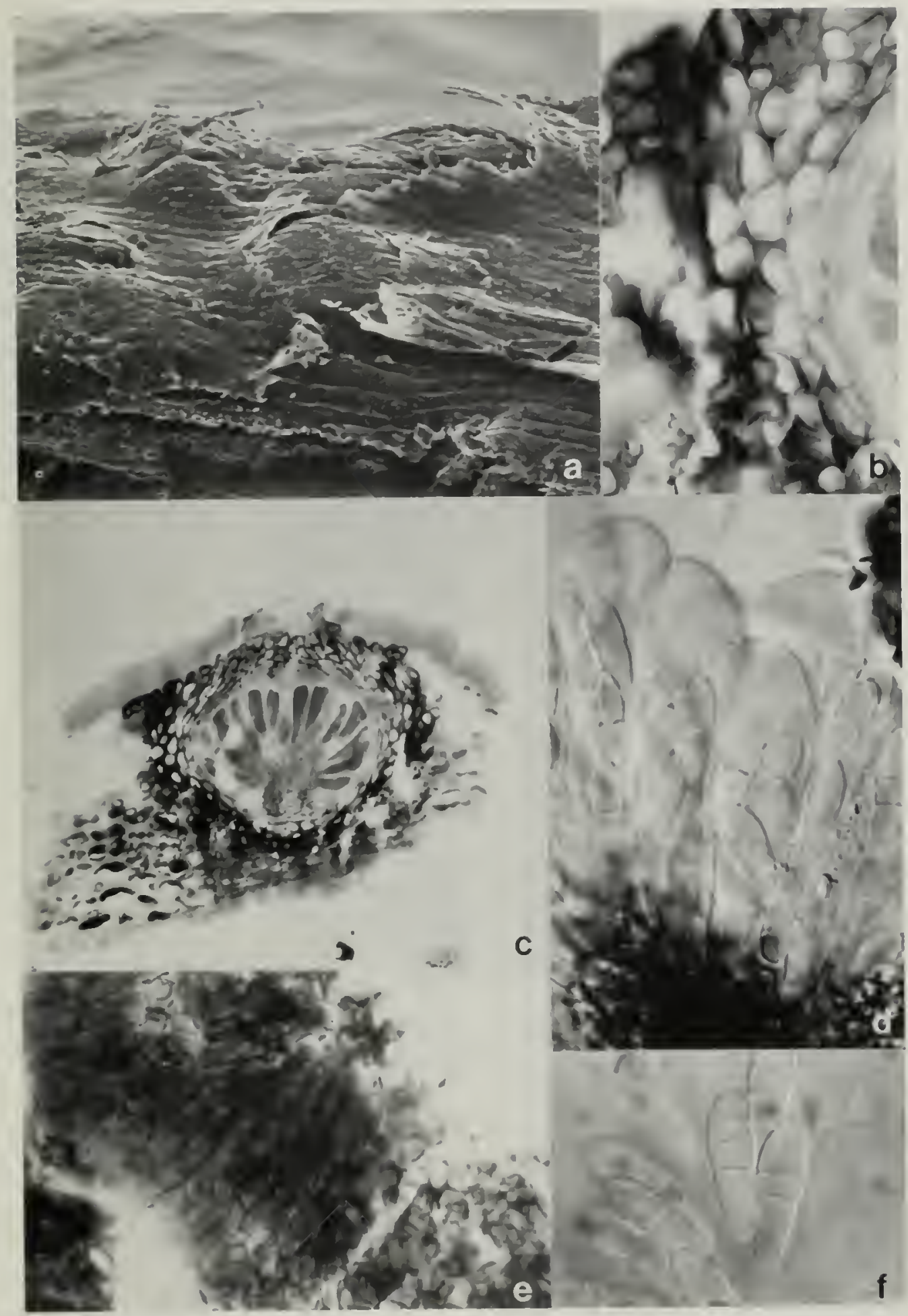

Figure 14. Saccothecium sepincola. a. SEM of immersed ascocarps, $x 125$. b. Iongitudinal median section through ascocarp wall, $\times 950$. c. Iongitudinal median section through ascocarp, $\times 225$. d. asci, $\times 1,050$. e. ascocarp wall surface, $\times 550$. f. ascospores, $\times 1.150$. All from lectotype of $S$. sepincola. 
Barbey-Boissier 501 (FH); Czechoslovakia: Weisskirchen, Ohrensdorf, as Sphaerulina intermiva, 25 Jan. 1912, Petrak, Fl. Boh. et Mor. exsic. Lfg. 4 Nr. 174. (FH); GERMANy: Leihterfeld bei Berlin, on Philadelphus sp., 1890, Sydow, Myc. March. 2934 (FH); ITALy: Selva, as Sphaerulina intermixta, Sept. 1878 , Saccardo, Myc. Ven. 1367 (FH).

- Saccolhecium sepincola var. abbreviata (M.C. Cooke) S.M. Huhndorf comb. nov. See Figure 15.

ESphaeria abbreviata M.C. Cooke, Handbook of British Fungi, p. 893. 1871. (Basionym).

ELeptosphaeria abbreviata (M.C.

Cooke) P.A. Saccardo, Sylloge

Fungorum Omnium Hucusque

Cognitorum Digessit P.A. Saccardo 2:26. 1883.

Ascocarps 117-144 $\mu \mathrm{m}$ diameter, $81-99 \mu \mathrm{m}$ high; wall 14-21 $\mu \mathrm{m}$ thick at the sides and apex, up to $27 \mu \mathrm{m}$ thick at the base, composed of 7-8 layers of pseudoparenchymatic, polygonal cells $(5-6 \times 6-12 \mu \mathrm{m})$. Papilla broadly rounded. Asci (32-)41-61 x (13-) 16.5-24.5 $\mu \mathrm{m}$. Ascospores (12-)13.7-16.6 × 3.6-5.7 $\mu \mathrm{m}$, 4-5(-6)-septate.

Holotype: Great Britain: On dead stems of bramble. Jan.-April (K).

Comments: Saccothecium sepincola is not uncommon, but it has been confused by mycologists over the years as exemplified by the number of name changes based on the fungus. Wehmeyer (1957) gave an account of the history and nomenclatural confusion surrounding this species, including its relationships with other organisms and its relationship to the later genus Pringsheimia Schulzer von Müggenburg. He also included a lectotypification of Saccothecium Fr. Barr (1972) lists the taxononic synonyms of Saccothecium sepincola. In some treatments. Pringsheimia sepincola is still used as the name for this species (Froidevaux 1973, von Arx and Müller 1975, Sivanesan 1984). Holm (1975) argued for the lectotypification of Saccothecium Fr. 1835 by $S$. scpincola $(F r$.$) Fr. 1849, which, as$ menioned above, apparently was already done by Wehmeyer (1957) (see Dennis 1978). Holm! (1975) does not mention the lectotypification hy Wehmeyer, so it is unknown if this lectotypification was not accepted or if Holm overlooked Wehmeyer's work. In any case, with lectotypification, Saccothecium is the correct name and Pringsheimia becomes a synonym.

Saccothecium sepincola is placed in the family Dothioraceae by Barr (1987a) and is characterized by sphaeroid ascomata with walls of pseudoparenchymatous cells and oblong to clavate asci with a thickened apex which arise from a central basal column or mound of hypothecial cells. The septate, hyaline, obovate ascospores usually have a vertical septum present in one or more of the central cells. These characters suggest a similarity to some Dothiora species with raised basal areas (Barr 1972).

Leptosphacria abbreviata is regarded as a variety of Saccothecium sepincola because ascospore sizes differ. The ascospores of $S$. sepincola are $17-22 \times 5-7 \mu \mathrm{m}$, whereas the spores of $S$. sepincola var. abbreviata are 12$16 \times 3-6 \mu \mathrm{m}$. The ascospores appear to be mature in specimens of both species. The ascocarps also differ in size between the iwo species in the specimens seen.

Some discrepancy exists between Cooke's (1871) description of Sphaeria abbreviata and the fungus that was present on the type specimen. Cooke's (1871) description includes "perithecia minute, in short parallel lines" and "asci very short and broad, elliptical. pyriform or obovate," which matches the fungus in the type. But then he describes spores that are "triseptate, slightly torulose and pale brown," which does not match this fungus. although occasionally the spores when mature may appear slightly pale brown. It is unclear whether his description was simply inaccurate or whether he was looking at wo different fungi. Only one fungus is present on the type specimen and it was similar to $S$. sepincola.

\section{Pseudosphaeriaceae}

- Leptosphaerulina pulchra (H.G. Winter) M.E. Barr. Contributions de 1'Institut Botanique de L'Université de Montréal 73:7. 1959. See Figure 16.
三Sphaerella pulchra H.G. Winter.
Hedwigia 11:145-146. 1872.
三Leptosphaeria pulchra (H.G. Winter)
P.A. Saccardo, Sylloge Fungorum
Omnium Hucusque Cognitorum Digessit
P.A. Saccardo 2:53-54. 1883. 


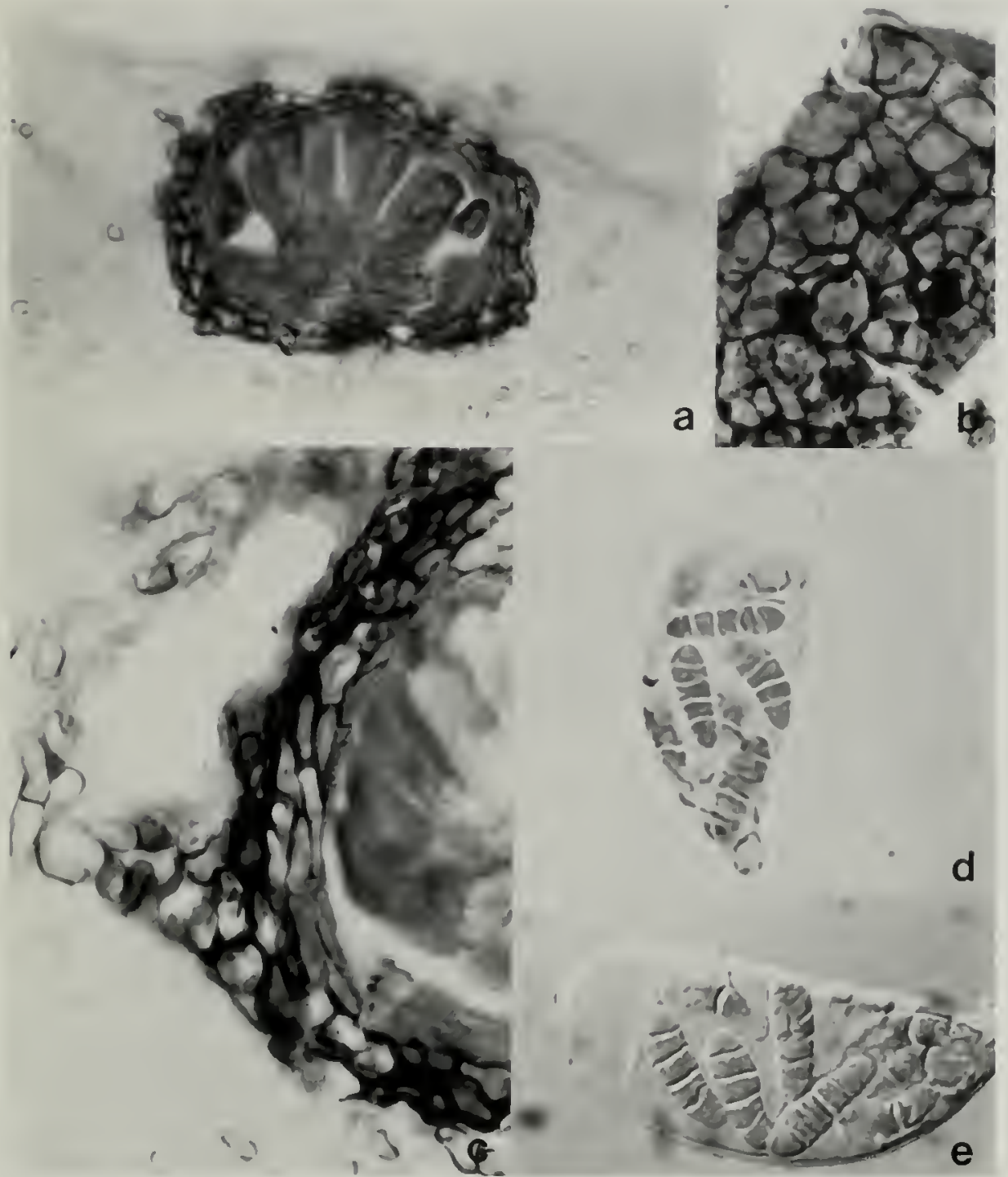

Figure 15. Saccothecium sepincola var. abbreviata. a. longitudinal median section through ascocarp, $\times 375$. b. ascocarp wall surface, $\times 550$. c. longiludinal median section through ascocarp wall, $\times 950$. d. ascus, $\times 1,050$. e. ascospores within an ascus, $\times 1,150$. All from holotype of $S$. sepincola var, abbreviata.

$\equiv$ Mycotodea pulchra (H.G. Winter) W.

Kirschstein, Annales Mycologici 34:201.

1936: Kryptogamenflora de Mark

Brandenburg und Angrenzender Gebiete herausgegeben von den Botanischen

Verein der Provinz Brandenburg 7(3):433. 1938.

= Leptosphaeria oligotheca F. Petrak \& H. Sydow, Annales Mycologici 22:359. 1924.

[Described from type material of Laestadia potentillae E. Rostrup, Botanisk Tidsskrilt 25:300. 1903.]

For other synonyms see Barr (1959).
Ascocarps thickly scattered, immersedsubcuticular, globose, papillate, glabrous, 50$75 \mu \mathrm{m}$ diameter, 55-75 $\mu \mathrm{m}$ high. Ascocarp wall of textura globulosa in surlace view: in longitudinal section uniformly $7.2-10.8(-12.7)$ $\mu \mathrm{m}$ thick, composed of 2-3 layers of pseudoparenchymatic, polygonal cells, outer 12 layers of brown-melanized cells (3.6-5.6 x $5.6-10.1 \mu \mathrm{m})$ covered hy a brown-pigmented crust, inner $1-2$ layers of hyaline, elongatecompressed cells $(2.1-3.6 \times 8.6-10.1 \mu \mathrm{m})$. Papilla short, erumpent, bluntly conical, 10-20 $\mu \mathrm{m}$ high, 10-21 $\mu \mathrm{m}$ wicle at apex, 21-29 $\mu \mathrm{m}$ 

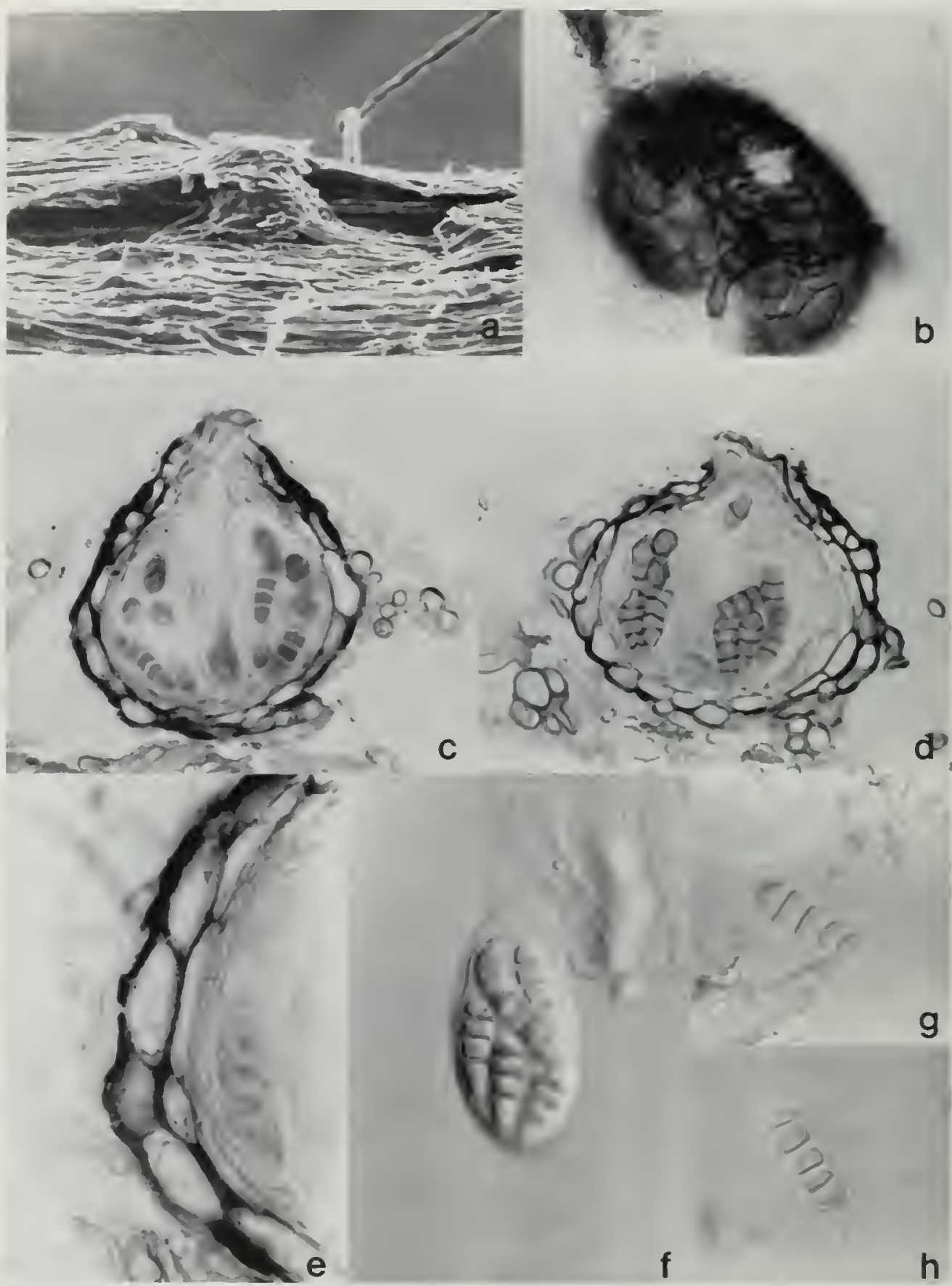

Figure 16. Leptosphacrulina pulchra. a. SEM of ascocarp, $\times 250$. b. ascocarp wall surface, $\times 550$. c, d, longitudinal median section through ascocarps, $\times 650$. e. longitudinal median sections through ascocarp wall, $\times 950$. f. ascus, x1,050. g. h. ascospores, x1,150. a. b. d, and ifrom holotype of Leptosphacria oligotheca: c. c. s. and $\mathrm{h}$ from neotype of Leptosphaerulinu pulchra. 
wide at base, neck wall 3.6-8.6 $\mu \mathrm{m}$ thick. composed of 2-3 layers of isodiametricelongate cells $(3.6-4.3 \times 3.6-6.5 \mu \mathrm{m})$ surrounding a circular ostiole (9-12 $\mu \mathrm{m}$ wide) without periphyses. Remnants of interthecial tissue remain between and above the asci. Asci $32-45 \times 15-20 \mu \mathrm{m}$, few, basal, fasciculate. ovoid-saccate, thick-walled, sessile, rounded apex, without apical chamber, with 8 tri- to tetraseriate ascospores. Ascospores 17.2-20.8 $\times 5.7-7.2 \mu \mathrm{m}$, clavate to obovoid, bipolarly asymmetrical with broadly rounded apical end cell and acutely rounded basal end cell, straight; 4(-5)-septate, septa unevenly distributed, order of septation $3: 1: 2: 4$, primary septum supramedian and constricted, a single vertical septum occasionally present in the central cells; subhyaline to pale brownish yellow, wall smooth, without sheath or appendages.

Holotype: Austria: Ad caules foliaque aridos Potentillae caulescentis, "am Martinstein bei Seis in Tyrol" 1870 von v. Hausmann gesammelt (B), (n.v.). presumed destroyed.

Neotype: United States: Maine: Basin Pond, Baxter St. Park, July 5, 1962, MEBB \# 3316 (NY).

Other material examined: CANADA: Labrador, Newfoundland, Blanc Sablon, July 19, 1957, R.T. Wilce \#161 (NY). ICELAND: on Potentilla maculata, type material of Laestadia potentillae Rostrup, July 14, 1884 (Holotype of Leptosphaeria oligotheca, C). UNITED STATES: Maine: Mt. Katahdin, Baxter St. Park, Tablelands from Saddle Trail, ca. 4200', Aug. 3 , 1962. MEBB \# 3546 (NY); NEW HAMPSHIRE: Mt. Washington, on Potentilla tridentata, June 9, 1894 (FH as Sphaerulina potentillae): Mt. Monadnock, near Dublin, June 27, 1961. MEBB \# 2927 (NY).

Comments: Leptosphaerulina pulchra is placed in the family Pseudosphaeriaceae because of the minute, sphaeroid-globose ascocarps with a very thin wall composed of pseudoparenchymatous cells and the interthecial tissues. The species is recognized readily on the basis of its saccate asci, ascospore shape, and septation. Barr (1959) mentions the presence of a vertical septum in the central cells, but in most of the collections seen, vertical septa were lacking.
Still, the obovate, asymmetrical ascospore shape is distinctive.

The holotype of Leptosphaerulina pulchra at $\mathrm{B}$, not located, is presumed to have been destroyed with the rest of the ascomycete collection during World War II. Also unsuccessful were attempts to locate authentic material of Winter or of the collector, von Hausmann. Because of this, a neotype for $L$. pulchra was chosen (MANE: Basin Pond, Baxter St. Park, July 5, 1962, MEBB \# 3316) from the M.E. Barr collection now at NY. The neotype reflects both the original description and the current, well-established concept of this species.

Leptosphaeria oligotheca is synonymous with Leptosphaerulina pulchra. When Petrak and Sydow (1924) originally described Leptosphaeria oligotheca from material on the type of Laestadia potentillae, on stems of Potentilla maculata, they did not segregate any of the material as the holotype for L. oligotheca and none could be found with their herbarium specimens at $\mathrm{W}$ or $\mathrm{S}$. The type specimen of Laestadia potentillae at $\mathrm{C}$ contained abundant material matching the description of Leptosphaeria oligotheca, so a portion was segregated as the holotype of that fungus.

Barr (1959) mentions several other species whose descriptions suggest they may be synonymous with Leptosphaerulina pulchra. One of these was Sphacria minima Duby in C. Roumeguère, Fungi Selecti Gallici Exsiccati, Century 7, No. 694. Anno 1880. Examining specimens from the exsiccatae sets at G, FH, NY, and ILL showed that they included many ascocarps, but none contained asci or ascospores. Therefore, it was impossible to resolve the placement of this species.

- Diadema obtusa R.A. Shoemaker \& C.E. Babcock, Canadian Journal of Botany 67: 1353-1354. 1989. See Figure 17.

Ascocarps thickly scattered, immersedsubcuticular becoming erumpent, globose, glabrous to slightly tomentose, with smooth brown hairs, 100-150 $\mu \mathrm{m}$ diameter, 120-150 $\mu \mathrm{m}$ high. Ascocarp wall of textura angularis in surface view; in longitudinal section (7.5-) $10-18 \mu \mathrm{m}$ thick at sides and base. composed of 2-3 layers of brown-melanized, polygonal. pseudoparenchymatic cells $(1.8-4.3 \times 7-1)$ 


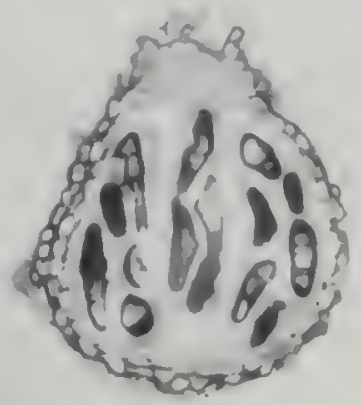

a
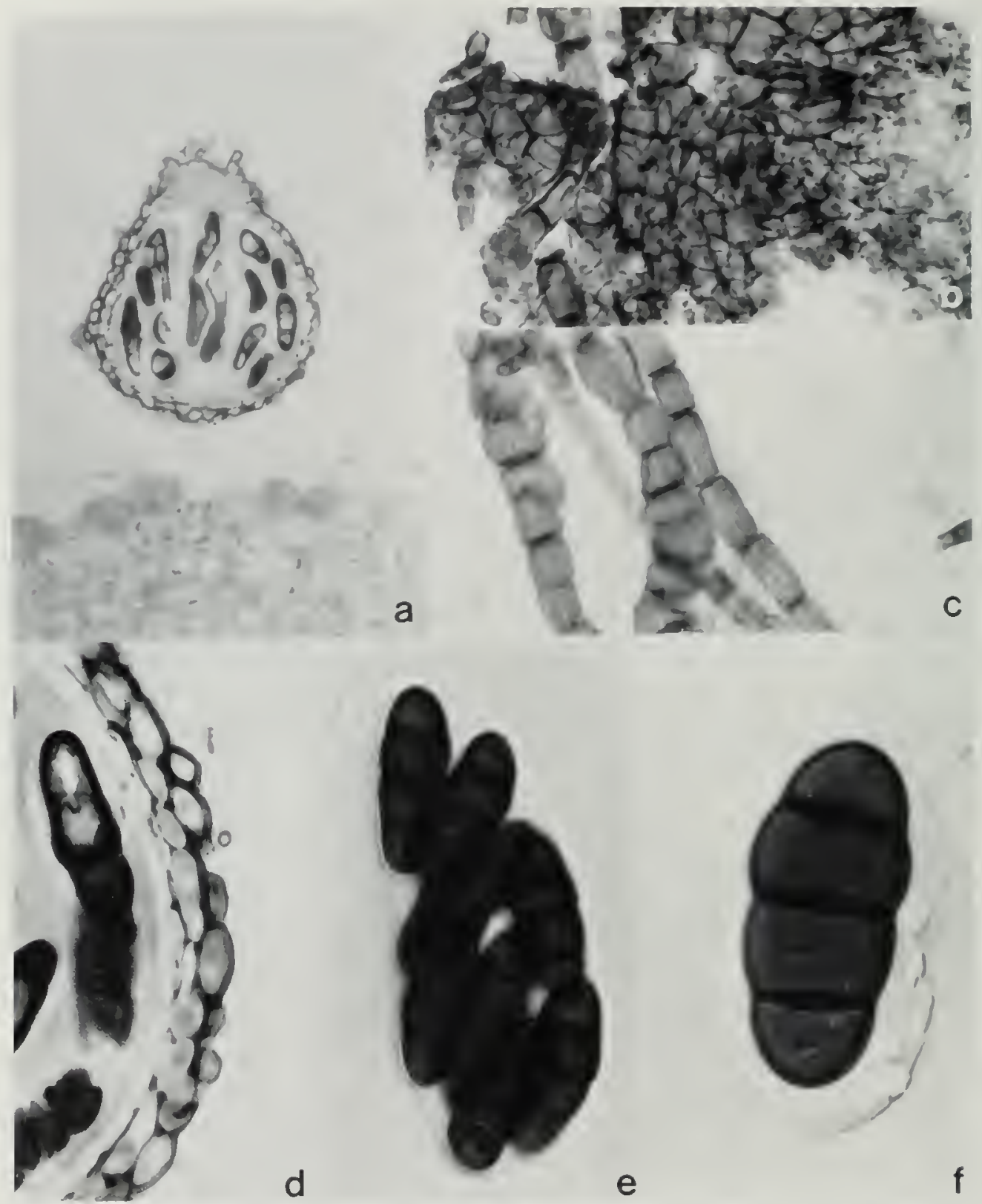

e

Figure 17. Diadema obrusa. a. longitudinal median section through ascocarp, $x 250$. b. ascocarp wall surface, $\times 550 . c$. hyphae on substrate surface, $x 550$. d. longitudinal median section through ascocarp wall. $\times 950$. c. ascus, $\times 525$. f. ascospore, $\times 1.050$. All from collection 123871. on Potentilla agrophilla.

$\mu \mathrm{m})$. Apex broadly rounded. $18-27 \mu \mathrm{m}$ lhick. 45-65 $\mu \mathrm{m}$ diameter, composed of 2-3 outer liayers of brown-melanized, isodiametric cells (3.6-5.4 $\mu \mathrm{m}$ diameler) wilh 6-8 layers of hyaline pscudoparenchyma below center. opening area nol seen, possibly discojd, caplike opening lacking, ostiole not seen. Interthecial tissues present. Asci (100-)120-145 x (30-)

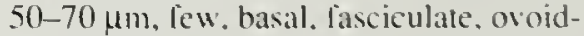
saccate to clavatc, thick-walled, short-stalked. rounded apex, with apical chamber, with $\&$ irito tetraseriate ascospores. Ascospores (41.5-) $45-50(-55) \times(15-17-) 19-23 \mu m$. broadly lisiform. aculely rounded end cells, second cell 
enlarged, straight to slightly curved, occasionally flattened in one plane: 3 -septate, septa slightly unevenly distributed, order of septation $2: 1: 2$, primary septum median and constricted. slightly constricted at other septa; brown, wall smooth, sharply delimited sheath entirely surrounding spore $(5-7.5 \mu \mathrm{m}$ thick), without appendages.

Holotype: INDIA: KaSHMIR: 123831(b), on

Trisetum spicatum, Pensi La, Zaskar, $16.500 \mathrm{ft}$. W. Koelz (5906). 23 July 1933, TYPE, ex Herb. Wehmeyer, as Leptosphaeria hollosiana nom. nov. (DAOM).

Other material examined: INDIA: 123871, on Potentilla agrophylla Wall., Spiti Valley, Bara Lacha Pass, $16,500 \mathrm{ft}$, Bhagwan Singh (5), 8 July 1932, ex Herb. Wehmeyer, as Leptosphaeria hollosiana nom. nov. (DAOM).

\section{Comments: Shoemaker and Babcock (1989a)} established the new genus Diadema for a group of alpine fungi with relatively large, very dark brown ascospores. They did not place the genus within a family or order. Eriksson and Hawksworth (1990) placed it in the Dothideales but did not designate a family. In the present report I treat it under the Pseudosphaeriaceae because it resembles Wettsteinina Höhnel; for example, some species have a peculiar disclike opening of the ascocarp and have interthecial tissue in the centrum. Diadema is characterized by globose. subcuticular ascocarps with a thin wall of brown polygonal cells and broadly fusiform ascospores that are dark brown and have a prominent sheath.

Wehmeyer (1963) published the name Leptosphaeria hollosiana for Leptosphaeria maritima L. Hollós because the latter binomial was predated by L. maritima (Cke. \& Plowr.) Sacc. He applied the new name to several collections from India and Pakistan, including two collections on Potentilla. Shoemaker and Babcock (1989a) described two new species of Diadema from these collections, including the type of the genus, D. acuta. on Trisetum spicatum (L.) Richt., and $D$. ohtusa, also on that host. The collections on Potentilla were also determined to be $D$. obuusa. The collection on Potemilla served as the basis for this description and plate beciuse of the Rosaccous host and because it had numcrous ascocarps. The other collections of $D$. obtusa were sparse.
As Shoemaker and Babcock (1989a) noted, the ascocarp opening mechanism in this species is not clearly understood. It is not distinctly caplike but in vertical section becomes almost papillate (Figure 17a). The entire upper section of the wall is subtended by hyaline pseudoparenchyma. Interthecial pseudoparenchymatic threads occurred between the asci. Also, coarse, brown hyphae were seen on the host surrounding several of the ascocarps, and some of the ascocarps were not glabrous but had tapered hairs at the top. I did not see the ascospores flattened in one plane. as did Shoemaker and Babcock (1989a). Shoemaker and Babcock (1989a) suggested that the generic placement of this species is not ideal because several characters were not identical to those of the type species. The overall aspect of this species, however, suggests an affinity with the type species, and that it is adequately placed in this genus. It appears that certain characters. such as the ascocarp cap and interthecial tissues, are variable among collections and may depend on the maturity of the specimen, as was also noted by Shoemaker and Babcock (1989a). Species of Wettsteinina are similarly variable. either showing a disclike cap or an ostiolar opening to the ascocarp; species with either character state are adequately retained within the genus because of overall resemblances (Shoemaker and Babcock 1987). Thus, such varjation does not appear sufficient to exclude species from these genera.

- Diadema sieversiae (C.H. Peck) S.M. Huhndorf comb. nov. See Figure 18. $\equiv$ Lophiostoma sieversiae C.H. Peck. New York State Museum Bulletin 167:44. 1913. (Basionym). इWettsteinima sieversiae (C.H. Peck) M.E. Barr, Canadian Journal of Botany 45:1042. 1967.

= Massaria sieversiae F.E. Clements. Cryptogamae Formationum Coloradensium, Century III, No. 234. Anno 1906. Nom. nud. Art. 36.1. $\equiv$ Leptosphaeria sieversiae (F.E. Clements) F. Petrak, Sydowia. Annales Mycologici 6(1-4):6. 1952. [Combination is not valid because the basionym is an invalidly published species.]

Ascocarps thickly scattered, immersedsubcuticular becoming crumpent. globose. 


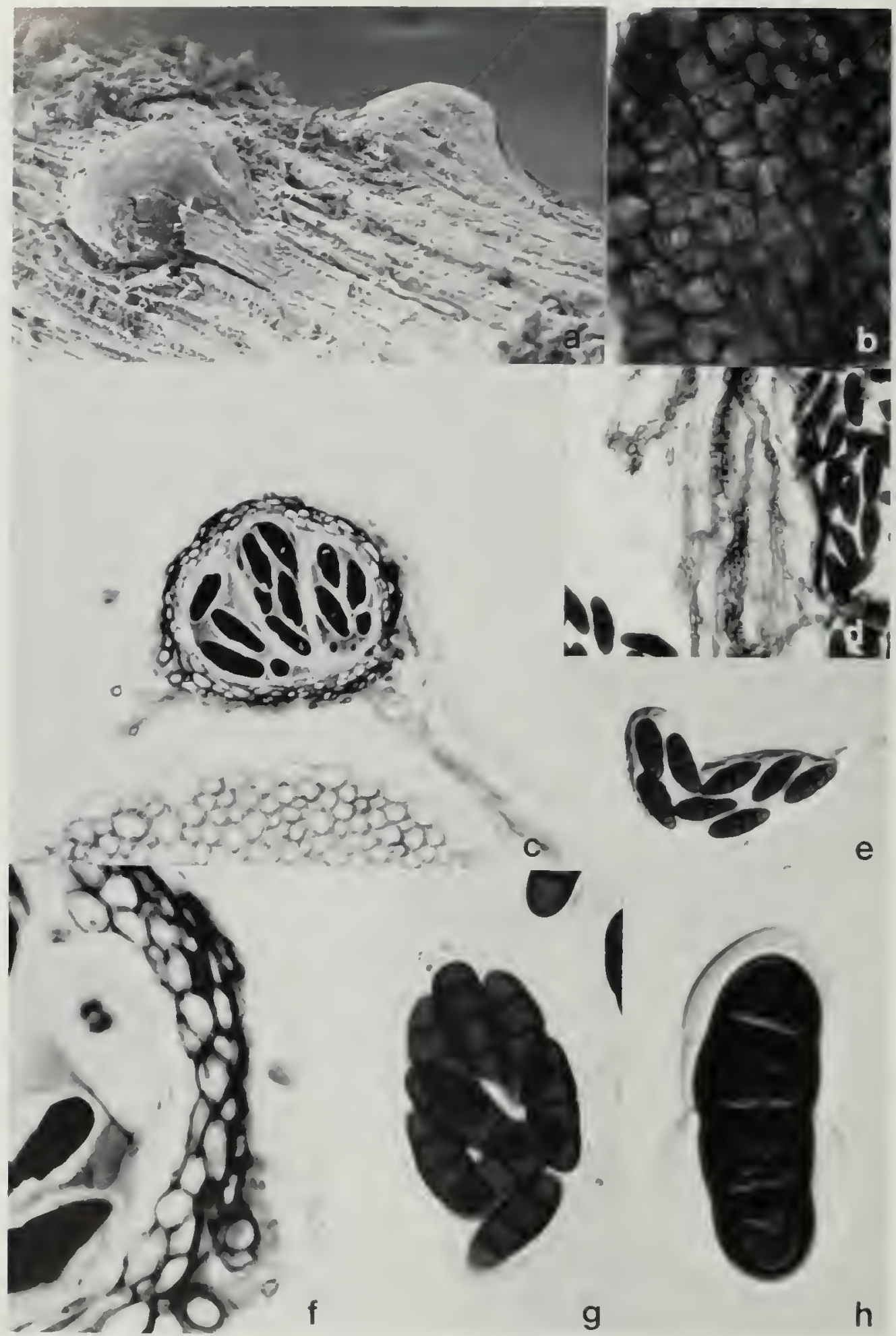

Figure 18. Diadema sieversiac. a. SEM of erumpent ascocarps, $x 125$. b. ascocarp wall surface, $x 550$. c. longitudinal median section through ascocarp, $\times 250$. d. hyphae on substrate surface, $\times 200$. e. elongated ascus, $\times 250$. f. longitudinal median section through ascocarp wall. $\times 950$. g. ascus, $\times 525 . h$ ascospore. $\times 1,(150)$ a, $\mathrm{b}$ from holotype of $D$. sieversiae; $\mathrm{c}-\mathrm{h}$ from isotype of Massaria sieversiae. 
glabrous to slightly tomentose, with loose darkwalled, longitudinal hyphae on the substrate. surrounding and connecting the ascocarps, $130-190 \mu \mathrm{m}$ diameter, $120-175 \mu \mathrm{m}$ high. Ascocarp wall of textura angularis in surface view; in longitudinal section uniformly 12.6-20 $\mu \mathrm{m}$ thick, composed of $3-4$ layers of brownmelanized, pseudoparenchymatic, polygonal, isodiametric-elongate cells $(3.6-5.6 \times 7.2-13$ $\mu \mathrm{m})$ with a brown-melanized crust. at base $3-4$ inner layers of small, hyaline pseudoparenchyma. Apex broadly rounded, with inner 3-4 layers of hyaline, pseudoparenchymatic cells (2-5 $\mu \mathrm{m}$ diameter), no evidence of papillate or caplike opening, ostiole not seen. Interascal pseudoparenchyma present. Asci (110-)130$170 \times 40-70 \mu \mathrm{m}$, few, basal, fasciculate, ovoidsaccate, thick-walled, sessile, rounded apex. with apical chamber, with 8 tri- to tetraseriate ascospores. Ascospores (43.5-)50.6-56.0 $(-57.9) \times(16-) 20-23.5(-25.5) \mu \mathrm{m}$, broadly fusiform, with acutely rounded end cells, second cell enlarged, straight to slightly curved; 3-septate, septa slightly unevenly distributed, order of septation 2:1:2, primary septum slightly supramedian and constricted, occasionally constricted at other septa; brown, wall smooth, sharply delimited sheath entirely surrounding spore $[2.0-5.5(-10.5) \mu \mathrm{m}$ thick. often constricted at midseptum, sheath occasionally gelatinizing and becoming amorphous (7-12 $\mu \mathrm{m}$ thick)], without appendages.

Holotype: United States: Utah: 193727, on Sieversia turbinata (Rydb.) Greene, Big Cottonwood Canyon, Salt Lake Co., A.O. Garrett 702. 3 July 1913 (NYS).

Exsiccatae: United States: Colorado: Bottontless Pit, July 13, 1906. Clements, Crypt. Form. Colorad. 234 (isotype of Massaria sieversiae. NY, FH).

Comments: Diadema sieversiae, found on stems of Acomastylis turbinata, is characterized by globose ascocarps with thin walls of brown polygonal cells, dark-walled hyphae on the substrate, and broadly fusiform, dark brown ascospores with a prominant gelatinous sheath. It bears a strong resemblance to $D$. ohtusa, but in that species the spores are slightly shorter and the dark brown hyphac in the host are not as prevalent. The ascocarp shapes differ somewhat, but I also saw no indication of a cap or disclike opening mechanism in $D$. sieversiae. Interthecial tissues were seen between the asci.

Diadema sieversiue was described by Peck (1913) als a species of Lophiostoma, but it bears no compressed beak or ostiole that would warrant inclusion in that genus. Barr (1967) transferred it to Wettsteinina because of the medium- to small-sized ascocarps immersed in dead host tissues and the oblong to saccate asci interspersed with interthecial tissue. Shoemaker and Babcock (1987) excluded it from Wettsteinina because of the dark brown ascospores with thick septa that are unlike the usual spores for Wettsteinina. It was left in Lophiostoma and later (Shoemaker and Babcock 1989a) was not included in Diadema. Clearly this fungus does not belong in Lophiostoma, and it bears a much greater resemblance to Diadema than to Wettsteinina. Even if it ultimately does not stay in Diadema, because of the lack of a disclike cap opening (as suggested for D. obtusa by Shoemaker and Babcock 1989a), it seems useful to place this species in Diadema, in the hope that additional collections may be discovered.

Massaria sieversiae, which was transferred to Leptosphaeria, is synonymous with Diadema sieversiae. 


\section{Leptosphaeria Species Referable to the Hymenoascomycetes}

The following Leprosphaeria species are all referable to the class Hymenoascomycetes (sensu Barr 1987a). The presence of perithecia and unitunicate asci separates these fungi from those in the Loculoascomycetes possessing pseudothecia and bitunicate asci. The families represented are Clypeosphaeriaceae.

Diaporthaceae, and Amphisphaeriaceae.

\section{Clypeosphaeriaceae}

- Clypeosphaeria mamillana (E.M. Fries:E.M. Fries) J.B.E. Lambotte, Memoires de la Societe Royale des Sciences de Liege, ser 2, 14:128.

1887. See Figure 19. ESphaeria mamillana E.M. Fries:E.M. Fries. Systema Mycologicum 2:487. 1823.

= Sphaseria clypeiformis G. de Notaris. Memorie della Accademie della Scienze di Torino Series 2, No. 7, p. 113.1853:

Micromycetes Italici Novi vel Minus Cogniti 7, p. 113. 1845. Non Sphaeria clypeiformis L.V. de Lacroix in G.L. Rabenhorst.

$\equiv$ Clypeosphaeria notarisii $\mathrm{L}$. Fuckel, Symbolae Mycologicae, p. 117. 1870. ELeptosphaeria (Clypeosphaeria) norarisii M.C. Cooke. Grevillea 17:91. 1889.

See Barr (1989) for other synonyms.

Ascocarps scattered, separate or gregarious. immersed-subepidermal beneath blackened clypei, papilla crumpent. glabrous, conicglobose, 300-400 $\mu \mathrm{m}$ diameter, $400-450 \mu \mathrm{m}$ high. Ascocarp wall of textura angularis in surface view; in longitudinal section uniformly $18-25 \mu m$ thich, composed of 10-15 layers of hyaline, elongate-compressed, scleroplectenchymatic cells $(0.7-1.5 \times 7-15 \mu m)$, outer $2-3$ layers of hyaline, rounded, polygonal cells (2.0-3.6 $14 m$ diameter). Papilla conic. 130-160 1.m high, 50-75 $\mu \mathrm{m}$ wide at the apex, 150-225 $\mu \mathrm{m}$ wide at the base: wall $15-30 \mu \mathrm{m}$ thick at apex, 35-65 $\mu \mathrm{m}$ thick at base. composed of 10 15 layers of small, brown-melanized, thickwalled. rounded, polygonal cells at base (1.5$3.6 \mu \mathrm{m}$ diam). cells converging and appearing as elongate, setaelike structures at apex. surrounding a $25-50 \mu \mathrm{m}$ wide circular ostiole with periphyses. Paraphyses $0.5-1.5 \mu \mathrm{m}$ wide, numerous. Asci $150-170 \times 8-10 \mu \mathrm{m}$. unitunicate, numerous, basal to peripheral. cylindrical, short-stalked, rounded apex, apical ring $\mathbf{J}+$, with 8 overlapping uniseriate ascospores. Ascospores 21-26 x 5.7-8 $\mu \mathrm{m}$. ovoidoblong. straight to slightly curved: at times 1 septate near base, large cell appearing 3-septate with separation of cytoplasm: brown. smooth. without sheath or appendages, germ slits not seen.

Exsiccatae: Austria: On Rubus fruticosus, Fuckel. F. rhen. 1823 (FH): Mappen. on Epilobium angustifolii, as Sordaria clypeiformis f. Epilobii. Fuckel, F. rhen. 2036 (FH): Herb. Barbey-Boissier $146=$ F. rhen. 1823, as C. norarisii (NY): GREAT BRTralN: Lynn, on Epilobium hirsutum, as Sphaeria clypeata Nees.. Jan. 1877. Plowright. Sphaer. Brit. 57 (FH): ITALY: on Rubus fruticosus, as Sphaeria clypeiformis. Aug. 1857. leg. Caldesi. Rabenhorst. Herb. myc. 645 (FH): as Sphaeria clypeiformis, 1857, leg. Caldesi, de Notaris. Erb. Critt. Ital. 47 (FH): La Spezia. as C. norarisii, Aug. 1880. Roumeguere, F. Gall. exs. 2095 (NY): Vittorio (Treviso), on Rubus fruticosus, as C. noturisii. Sept. 1897. Saccardo, Mycotheca ital. 101 (NY): Conegliano, as C. notarisii. Aug. 1877. Mycotheca veneta 1159 (NY): St. Romani-adVigennam. as S. clypeiformis de Lcrx.. 1859. leg. T. de Lacroix, Rabenhorst, F. europ. 331 (RO).

Other material examined: ITALY: Capraria. on Rubus. as Sphaeria sepincola ruborum. 1837. 


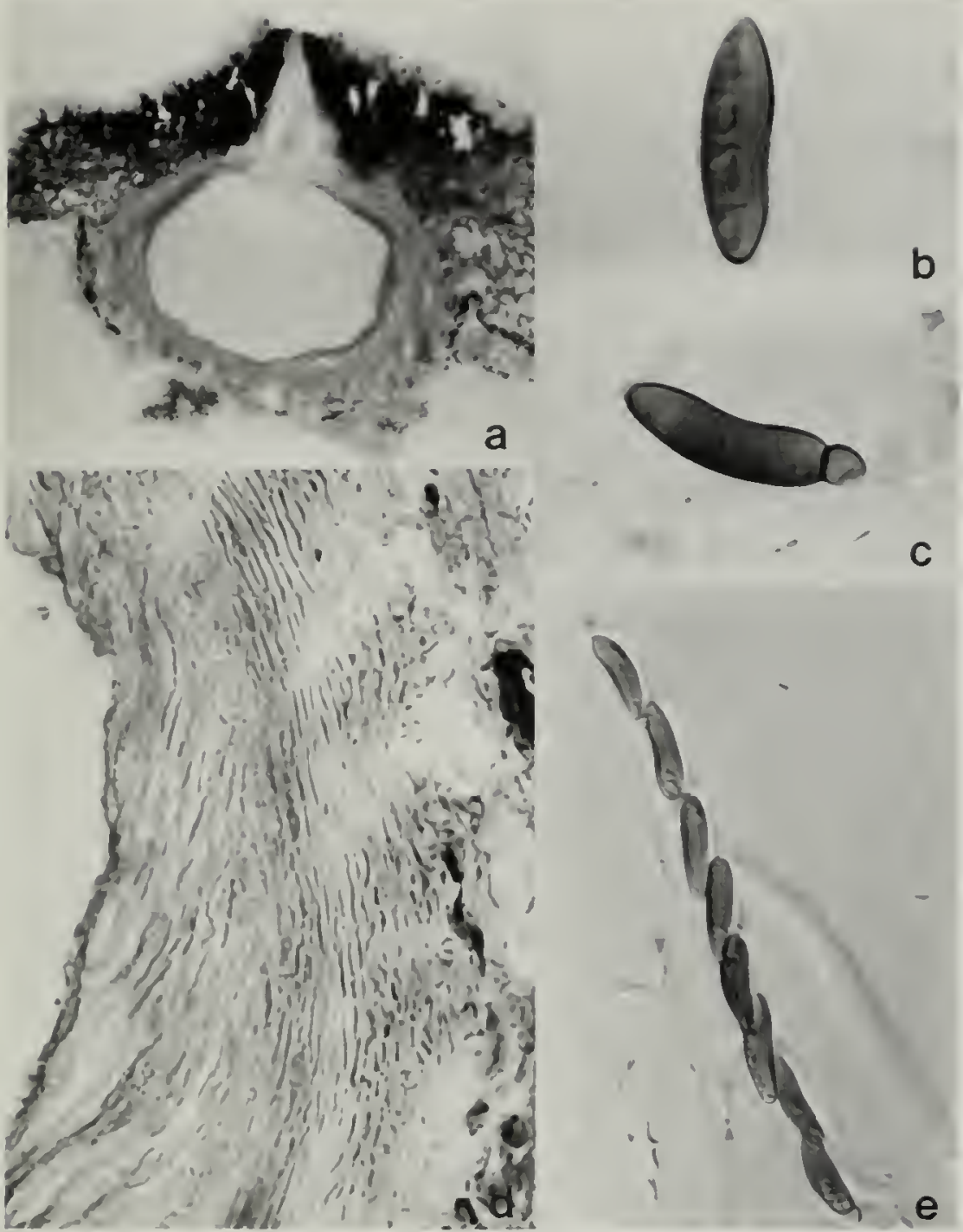

Figure 19. Clypeosphaeria mamillana. a. longitudinal median section through ascocarp, $x 100$. b, c. ascospores, $x 1,150$. d. longitudinal median section through ascocarp wall. $\times 950$. e. ascus, $\times 525$. All from lectotype of $C$. notarisii.

de Notaris (Lectotype of Sphaeria

clypeiformis): two collections of Sphaeria clypeata, 1840; Spezia, Aug. 1857, Herb. N.A. Pedicino, 1883; on Rubus, as S. clypeiformis. Mar. 17. 1842, de Notaris (all RO).

Comments: Clypeosphaeria notarisii, a synonym of Clypeosphaeria mamillana, is characterized by cylindrical asci with an elongate, $J+$ apical ring and curved, brown ascospores appearing 3-septate with separation of the cytoplasm. Barr (1989) gives the synonymy and a short history of

Clypeosphaeria and argues for the utilization of the family Clypeosphaeriaceae.

Clypeosphaeria was established by Fuckel (1870), who included $C$. notarisii as a new name for Sphaeria clypeiformis de Not. A specimen of Sphaeria sepincola ruborum was mentioned in the description of Sphaeria clypeiformis, and a collection of this at RO is here designated as the lectotype of $S$. clypeiformis (ITALY: Capraria, on Ruhus, 1837. de Notaris. RO). 


\section{Diaporthaceae}

- Diaporthe eres T.R.J. Nitschke, Pyrenomyeetes germanici, p. 245. 1867. See Figure 20.

= Sphaeria controversa J. Desmazierès (pro parte). Annales des Sciences Naturelles,

Paris, Botanique, Series 2. 17:102. 1842.

इ Leptosphaeria controversa (J.

Desmazierès) V. Cesati \& G. de Notaris,

Commentario della Societa

Crittogamologica Italiana 1:235. 1863.

EDiuporthe controversa (J.

Desmazierès) T.R.J. Nitschke in L.

Fuckel, Symbolae Mycologicae Nachtrag $1: 319.1871$.

See Wehmeyer (1933) for other synonyms.

Ascocarps scattered, separate or clustered, immersed-subepidermal often beneath blackened stromatic tissue, papilla erumpent singly or in loose clusters, glabrous, globose, flattened at top and base, $300-400 \mu \mathrm{m}$ diameter, 250 $350 \mu \mathrm{m}$ high. Ascocarp wall of textura angularis in surface view; in longitudinal section 25-35 $\mu \mathrm{m}$ thick at the sides, 15-20 $\mu \mathrm{m}$ thick at the base, composed of 7-8 layers of hyaline, elongate-compressed, scleroplectenchymatic cells $(0.7-1.5 \times 10-15 \mu \mathrm{m})$, wall near apex 45-50 $\mu \mathrm{m}$ thick, composed of 10-12 layers of brown-melanized, polygonal, isodiametric cells (2-3 $\mu \mathrm{m}$ diam). Papilla long cylindrical, central or eccentric, 125-180 $\mu \mathrm{m}$ high, $50-75 \mu \mathrm{m}$ wide; wall $25-35 \mu \mathrm{m}$ thick, composed of small, brown-melanized, thickwalled, rounded, polygonal cells (1.5-3.0 $\mu \mathrm{m}$ diameter), surrounding a $25-40 \mu \mathrm{m}$ wide circular ostiole with periphyses. Paraphyses $0.5-1.5 \mu \mathrm{m}$ wide, numerous, septate, unbranched. Asci $38-55 \times 6-8.5 \mu \mathrm{m}$. unitunicate. numerous, basal to peripleral, dehiscent, clavite, short-stalked, rounded apex, with 8 biseriate ascospores. Ascospores 10.5-13.5 x 2.0-3.6 $\mu \mathrm{m}$, fusiform, straight to slightly curved; I-septate, constricted: hyaline. with four distinct oil droplets, smooth, without sheath, occasionally with small, cellular bipolar appendages.

lsotype: France: Hahitat in caulibus plantarum. in ramis exsiccalis Fraxini, Rubi, Aceris Negundinis, etc. Desm. PI. Crypt. Fr. exs. XXVI 1255 (PC, FH, BPI).

Comments: Sphareria comrolversa (pro parte) is synonymous with Diaporthe reses (Welmeyer
1933) and is characterized by ascocarps immersed beneath blackened stromata, with central or eccentric, long cylindrical necks with periphyses. As they mature, the numerous asci loosen and become free within the centrum.

Ascospores are hyaline and 1-septate and have four distinct oil droplets.

The exsiccati collections all consisted of several different twigs of unknown identity, none of which appeared to be Rubus. mosi with varying amounts of the fungus on them.

\section{Amphisphaeriaceae}

- Discostroma fuscella (M.J. Berkeley \& C.E. Broome) S.M. Huhndorf comb. nov. See Figure 21.

ESphaeria (Obtectae) fuscella M.J. Berkeley \& C.E. Broome. Annals and Magazine of Natural History. London. Series 2, 9:325. 1852. (Basionym). $\equiv$ Leptosphaeria fuscella (M.J. Berkeley \& C.E. Broome) V. Cesati \& G. de Notaris, Commentario della Società Crittogamologica Italiana 1:236. 1863. = Sphacria corticola L. Fuckel, Symbolae Mycologicae, p. 114, 1870.

三Leprosphacria corticola (L. Fuckel) P.A. Saccardo, Michelia Commentarium Mycologicum Fungos in Primis Italicos 1llustrans 1:342. 1878; Fungi Italici autographice delineati (additis nonnullis extra-italicis asterisco notatis). Patavii. table 288.1878.

三Metasphaeria corticola (L. Fuckel)

P.A. Saccardo, Sylloge Fungorum

Omnium Hucusque Cognitorum Digessit P.A. Saccardo 2:166. 1883.

E Griphosphacria corticola (L. Fuckel)

F. v. Höhnel. Annales Myceologici 16:87. 1918.

三Clathridium corticola (L. Fuckel) R.A.

Shoemaker \& E. Müller. Canadian

Journal of Botany 42:404. 1964.

EDiscostroma corticola (L. Fuckel) 1.

Brockmann, Sydowia 28:313. 1975. = Sphaeria (Leprosphaeria) leiostega J.B. Ellis, Bulletin of the Torrey Botanical Club (and Torreya) 8:91. 1881.

ELeptosphacria leiostega (J.B. Ellis) J.B. Ellis. Catalogue of Plants Found in New Jersey. Geological Survey of New Jersey, Final Report of the State Geologist 2(1):525. 1889. 


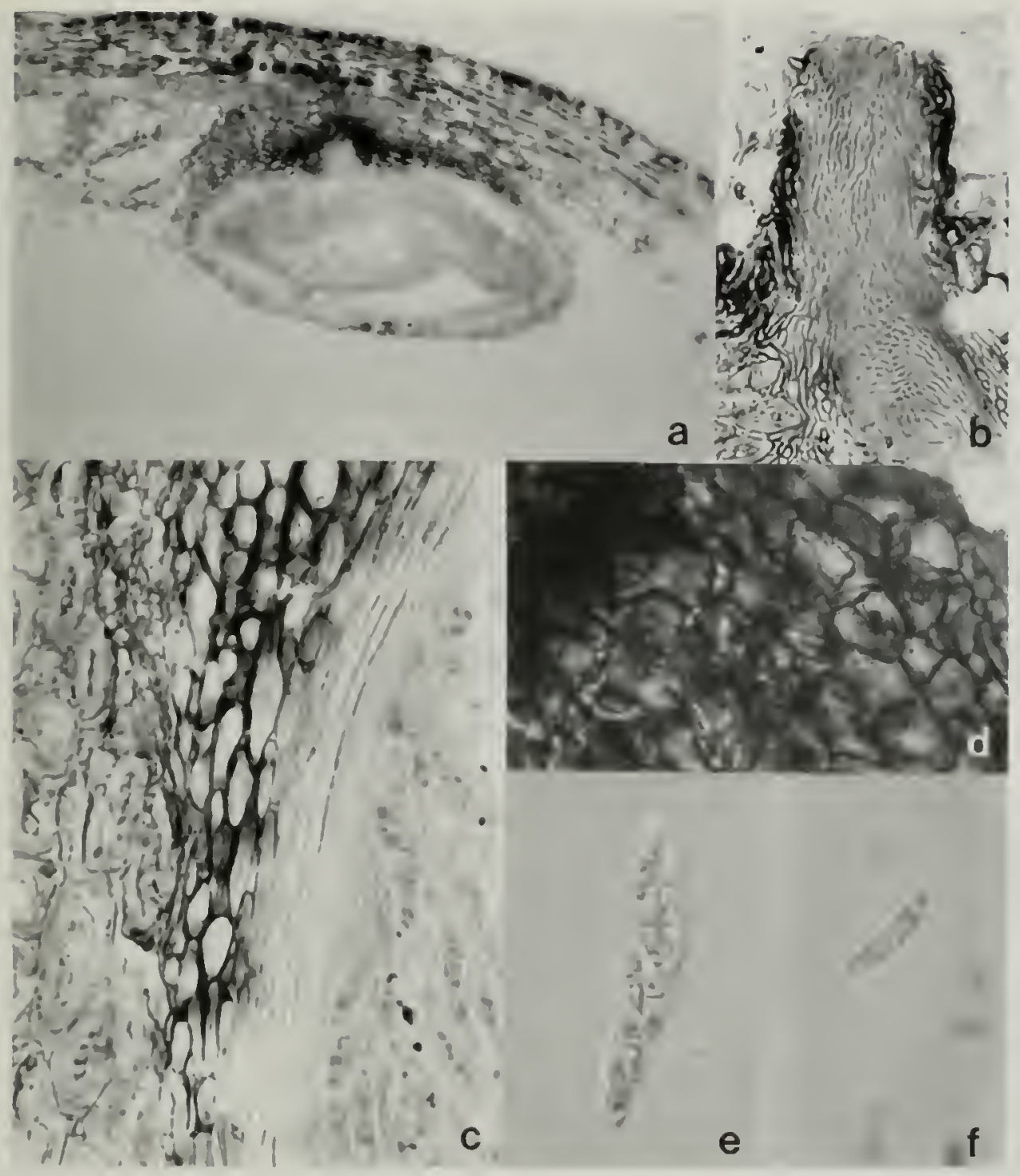

Figure 20. Diaporthe eres. a. longitudinal median section through ascocarp, $\times 150$. b. section through ascocarp neck showing periphyses, $x 400$. c. longitudinal median section through ascocarp wall, $x 950$. d. ascocarp wall surface, $\times 550$. e. ascus, $\times 1,050$. f. ascospore, x 1,150. All from type of Leptosphaeria controversa.

三Leptosphaeria lejostega (J.B. Ellis) F. Hazslinszky, Matematikai és

Természetludományi Közlemenyek

Vonatkozólag a Hazai Viszonyokra 25(2): 148. 1892.

三Metasphaeria lejostega (J.B. Ellis) P.A. Saccardo. Sylloge Fungorum Omnium Hucusque Cognitorum Digessit P.A.

Saccardo 2:164. 1883.

For other synonyms see Brockmann (1975).
Ascocarps scattered, separate or clustered, immersed-subepidermal beneath blackened clypei, glabrous, depressed globose, flattened top and bottom, with papilla protruding through surface, $300-500 \mu \mathrm{m}$ diameter, $150-250 \mu \mathrm{m}$ high. Ascocarp wall of textura prismatica in surface view; in longitudinal section $8-18 \mu \mathrm{m}$ thick at base, $18-27 \mu \mathrm{m}$ thick at sides, composed of 6-8 layers of brown, elongatecompressed, scleroplectenchymatic cells (12- 

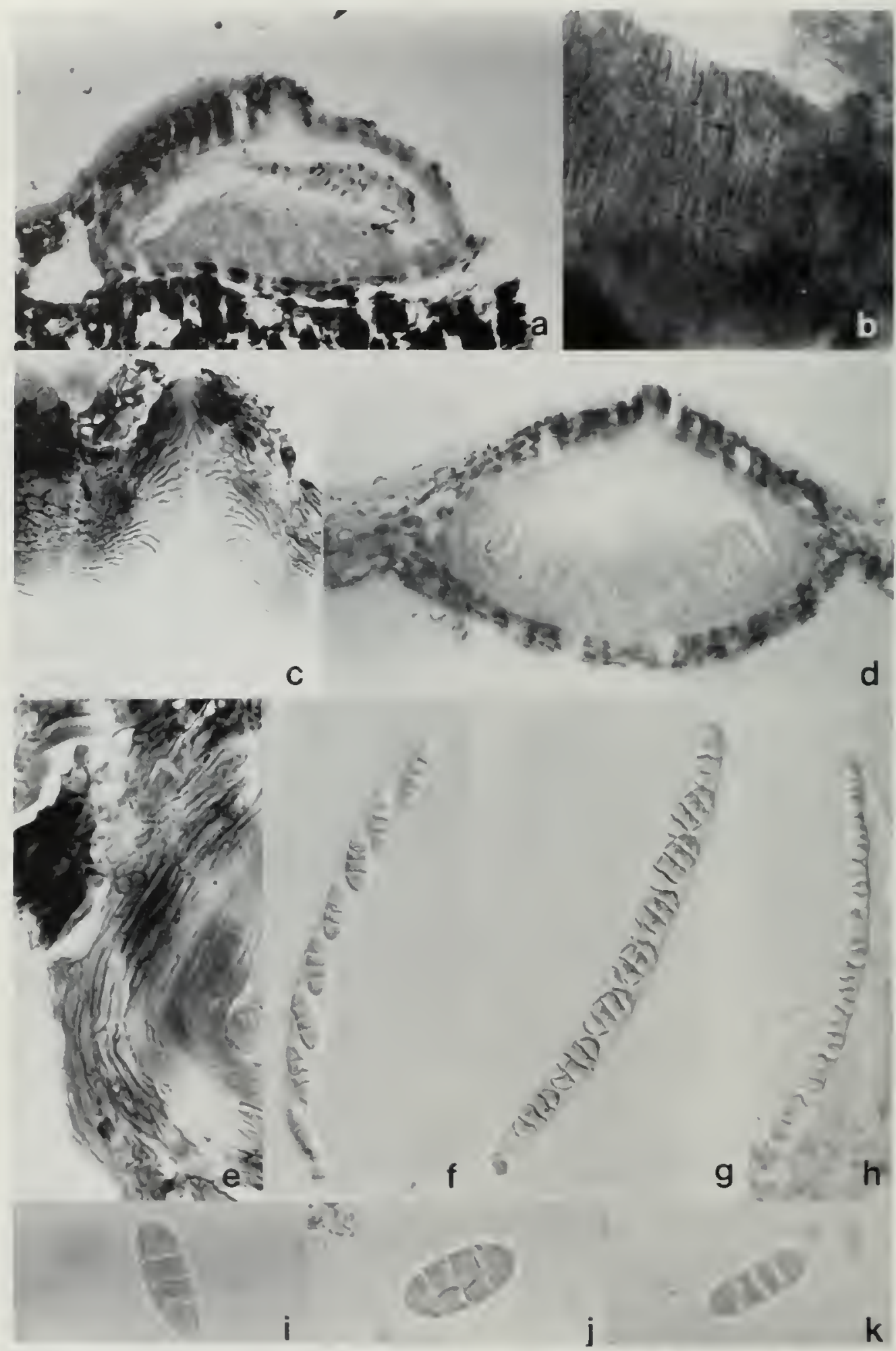

Figure 21. Discostroma fuscella. a. longitudinal median section through ascocarp, $\times 150$. b. ascocarp wall surface, $\times 5.50$. c. section through ascocarp wall nech region, $\times 550$. d. longitudinal median section through - ncarp. $\times 150$. e. longitudinal median section through ascocarp wall, $\times 950$. $\mathrm{f}$-h. asci, $\times 525$. $i-h$ ascospores. i c, c, $f$, and i from holotype of $D$. fuscella: d. g. and j from lectotype of Sphacrial leiessega: ") tspe of S corricola. 
$25 \times 2-3 \mu \mathrm{m})$; near apex, wall $2 \mathrm{l}-36 \mu \mathrm{m}$ thick. composed of $6-7$ outer layers of brown, polygonal-isodiametric cells $(7-11.5 \times 2-3$; $2.1-3.6 \mu \mathrm{m}$ diameter) and $6-7$ inner layers of compressed-elongate, scleroplectenchymatic cells. Papilla conical, 50-75 $\mu \mathrm{m}$ high, 20-30 $\mu \mathrm{m}$ wide at the apex, $35-50 \mu \mathrm{m}$ wide at the base; wall 7-10 $\mu \mathrm{m}$ thick, composed of 7-10 layers of small, brown-melanized, thick-walled, rounded, polygonal cells, surrounding a 10-20 $\mu \mathrm{m}$ wide circular ostiole with periphyses. Paraphyses $0.5-1.5 \mu \mathrm{m}$ wide, numerous, septate, unbranched. Asci (101-)1 15-132 $(-137) \times 7-12(-14) \mu \mathrm{m}$, unitunicate, numerous, basal in a broad hymenium, cylindrical, shortstalked, rounded apex, apical ring $\mathrm{J}+$, with 8 overlapping uniseriate ascospores. Ascospores 15-21 x 5-9.5 $\mu \mathrm{m}$, ellipsoidal, end cells rounded: 3 -septate, septa often close together and end cells longer, seldom with 4 or more septa (up to 7), occasionally with vertical septa in central cells only or in every cell, order of septation variable, often $2: 1: 2$, primary septum median and occasionally constricted; hyaline, smooth, without sheath or appendages.

Holotype: Great Britain: Easton, Norths., on dead twigs of rose (Rosa sp.), March 9, 1850 (K).

Exsiccatae: AustrIA: Fuckel, Fungi Rhenani 911 (1sotype of Sphaeria corticola, G, FH); Czechoslovakia: Welka, on Prumes spinosa, as Metasphaeria corticola f. Pruni, Oct. 3, 1912. Petrak, Fl. Boh et Mor. exsic. 6I (FH); Welka, on Rosa canina, as Metasphaeria corticola $\mathrm{f}$. Rosae, Apr. 17. 1912, Petrak, Fl. Boh et Mor. exsic. 62 (FH); Ohrensdorf, on Rubus thyrsoideus, as Metasphaeria corticola f. Rubi, Sept. 25, 1911, Petrak. Fl. Boh et Mor. exsic. 63 (FH); Sweden: Lockerud, Wenenborg, on Rubus fruticosus, as Leptosphaeria lejostega (Ellis) Eliasson, Aug. 1892, Rehm, Asc. 1189 (FH); United States: New Jersey: Newfield, as Sphaeria (Lept.) leiostega, Ellis, N. American Fungi 888 (NY).

Other material examined: Austria: Nassau, on Prumus domestica and P. spinosa, Fuckel (Isotype, as Metasphacria corticola (Fuckel) Sacc., FH); United States: Kansas: Rockport, Rooks Co., on Cormus asperifolia. as Metasphaeria leiostega, Dec. 24, 1894, E. Bartholomew (FH); Rooks Co., on Rihes aureum, as Clypeosphaeria hendersonia 2555. Mar. 15, 1899, E. Bartholomew (NY); MichIGAN: 573. Ann Arbor, on Ribes frondism, as Metasphaeria leiostega, Apr. 1, 1893, L.N. Johnson (NY); NEw JERSEY: Newfield, on wild rose (Rosa hwcicha?), May 6, 1879, J.B. Ellis (lectotype of Sphaeria leiostega, NY);

Newfield, on Vihumum lentago, as Sphaeria leiostega, Dec. 1878, J.B. Ellis (NY);

Newfield, Gloucester Co., on Hickory, as Sphacria leiostega (NY); on Staphylea trifolia, as Metasphaeria leiostega, Dec. 23, 1891 (NY); on Viburnum, as Metasphaeria leiostega (NY); 1273, on wild currant, as Metasphaeria leiostega. Jan. 4. 1890 (NY); on Comptonia, as Metasphaeria leiostega Mar. 1890, J.B. Ellis (NY); Vineland, on Vaccinium corymbosum, as Sphacria leiostega, Jan. 22, 1878; Jan. 10, 1880 (NY); NEw YORK: Washington Co., Vaughans, J. Vaughan's Copse, near Devines Woods, north of Hudson Falls, on Ribes americanum (florichum), as Metasphaeria leiostega. Apr. 24, 1917, P.P. 25255, S.H. Burham (FH).

Comments: Discostroma fuscella is characterized by subepidermal perithecia with short protruding papillae, cylindrical asci with a J+ apical ring and hyaline, 3 -septate, elliptical ascospores with broadly rounded ends. Certain collections have wider spores and vertical septa, most often in the central cells, but often also in the end cells. Most notably, vertical septa are found in the lectotype of Sphacria leiostega. All other characters are identical to those of D. fuscella.

Discostroma corticola, the most common name of this fungus, is identical to the earlier named Sphaeria fuscella. Previous interpretations of Sphacria fuscella have caused some confusion in the literature. The type material contains a fungus resembling $D$. corticola, with hyaline ascospores. However, it has been considered to be a 3-septate, brown-spored fungus because of Berkeley and Broome's (1852) description of ascospores as "pale brown, oblong-elliptic, obtuse, triseptate. sometimes slightly curved." In the accompanying Latin description they do not mention the color of the ascospores. On the type material (K), labeled "Sphaeria fuscella B \& B. In Rosa, Easton, March 9, 1850," are three rose twigs, one of which is labeled (with a dotted line and a figure) as Sphaeria (Subtectae) intermiva B $\& \mathrm{~B}$. The other two twigs contain abundant 
raterial of the hyaline-spored fungus resembling $D$. corticola. Also on this material is a figure ol Sphaeria fuscella showing an ascus and spores with "hyaline" written next to the spores. Wehmeyer (1957) suggested that a mixture of fungi in this and another collection of S. fuscella resulted in a confused description. He felt the name should be a nomen dubium and not used as a basis for later names. I believe, from the description and the fungus found on the type material, and from the figure on the type material, that Berkeley and Broome's confused description was not based on a mixture of fungi but was a miscommunication of the actual information. I believe they were aware that $S$. fuscella had hyaline, not brown spores; thus, it is suitable for use as a basis for later names. 


\section{Species incertae sedis}

The following species were examined but could not be placed in any taxa with certainty because the type specimens contained no ascocarps and no other collections were available on which to base the descriptions.

-Leptosphaeria eriobotryae H. Sydow, P. Sydow \& E. Butler, Annales Mycologici 9:409. 1911.

Holotype: Hab. in foliis Erioborrya japonicae, Saharanpur, 27. 6. 1906, leg. Inayat (E.J. Butler no. I365). (S) Isotype: (W. HCIO)

-Leptosphaeria minima (J.E. Duby) ex P.A. Saccardo, Michelia Commentarium Mycologicum Fungos in Primis Italicos Illustrans 2:320. 1881 .

ESphaeria minima J.E. Duby in C. Roumeguère, Fungi Selecti Gallici Exsiccati, Century 7, No. 694. Anno 1880. Nom. nud.

= Mycotodea minima (J.E. Duby ex P.A. Saccardo) W. Kirschstein in O.C. Schmidt, Kryptogamenflora der Mark Brandenburg und Angrenzender Gebiete herausgegeben von den Botanishen Verein der Provinz Brandenburg 7(3):432. 1938.

Isotype: Sur les feuilles du Potentilla argentea L., Mende, Prost. (G, FH, ILL, NY)

-Leptosphaeria sorbi A. Jaczewski, Annales Mycologici 1:30. 1903.

Holotype: in foliis vivis Sorbi aucupariae, IX. 181914 , Gjatsk. Smolensk. Gouv. Jaczewski. (LE) 


\section{Appendix: Leptosphaeria Species Described from the Rosaceae}

The following is a list of all Leptosphaeria species described from the Rosaceae and the species" nomenclatural synomyms. This information is taken from Crane and Shearer (1991). The taxonomic synonyms applied herein and the herbaria contacted have been added. The fungal specimens cited in this dissertation were studied at or on loan from various herbaria. Requests were made to various herbaria for type material for all of the described species. Unfortunately, type material could not be located for all of the species because either the material was destroyed, lost, or not deposited at a certain institution, or the institutions involved did not reply or do not lend specimens. Abbreviations follow Holmgren et al. (1981).

L. abbreviata (M.C. Cooke) P.A. Saccardo, Sylloge Fungorum Omnium Hucusque Cognitorum Digessit P.A. Saccardo 2:26. 1883. 三Sphaeria abbreviata M.C. Cooke, Handbook of British Fungi, p. 893. 1871. On dead stems of Rubus sp., Rosaceae. Great Britain.

\#Saccothecium sepincola (E.M. Fries:E.M.

Fries) E.M. Fries var. abbreviata S.M.

Huhndorf, comb. nov.

L. aculeorum G. Passerini, Atti della R. Accademia dei Lincei Memoriae. Rome, Series 4. 6:458459. (1889) 1890. On stems of Rosa canina L., Rosaceae. Italy. (non vidi). Type material was not found at PARMA. PISA. PAD.

L. arunci S.M. Zeller, Mycologia, Lancaster. Pennsylvania 19:134-135. 1927. On dead stems of Aruncus silvestris Kostel. (=Aruncus dioicus (Walter) Femald), Rosaceae. United States (Oregon).

= Kalmusia clivensis (M.J. Berkeley \& C.E. Broome) M.E. Barr.

L. cercocarpi H. Sydow \& P. Sydow, Annales Mycologici, Berlin 5:339. 1907. On dead Icaves of Cercocarpus ledifolius Nutt. ex Torr. \& Gray, Rosaceae. United States.

L. concentrica J.B. Ellis \& B.M. Everhart, The North American Pyrenomycetes. A Contribution to Mycologic Botany, p. 354. 1892. On leaves of Malus sp., Rosaceac. United States. $\equiv$ Paraphaecosphacria concentrica (J.B. Ellis \& B.M. Everhart) S.M. Huhndorf, comb. now.
L. coniothyrium (L. Fuckel) P.A. Saccardo,Nuovo Giornale Botanico Italiano e Bolletino della Società Botanica Italiana. Firenze 7:317. 1875. 三Sphaeria coniothyrium L. Fuckel, Symbolae Mycologicae. p. I15. 1870. $\equiv$ Melanomma coniothyrium (L. Fuckel) L. Holm, Symbolae Botanicae Upsalienses. Uppsala ] 4(3):56. 1957. On siems of Almus glutinosa (L.) Gaertner. Broussonetia sp., Chimonanthus sp.. Kerria sp., Menispermum canadense L., Rosa sp.. Rubus fruticosus L.. Salix vitellina L.. Sambucus nigra L..

Betulaceae, Moraceae. Calycanthaceae,

Rosaceae, Menispermaceae. Salicaceae. Caprifoliaceae. Austria, France, Germany. Italy, Portugal.

EKalmusia coniothyrium (L. Fucke]) S.M. Huhndorf, comb. nov.

L. controversa (J. Desmazierès) V. Cesati \& G. de Notaris, Commentario della Societa Crittogamologica Italiana. Milan ]:235. 1863. ESphaeria controversa J. Desmazierès, Annales des Sciences Naturelles. Paris. Botanique, Series 2, 17:102. 1842. EDiaporthe controversa (J. Desmazierès) T.R.J. Nitschke in L. Fuckel. Symbolae Mycologicae Nachtrag 1:319. 1871. On plant stems, on dry branches of Acer sp.. Fraximus sp.. Rubus sp.. Aceraceae. Oleaceae.

Rosaceae. France.

=Diaporthe eres T.R.J. Nitschke, fide L.E. Wehmeyer. The Genus Diaporthe Nitschke and its Segregates, p. 63. 1933.

L. corticola (L. Fuckel) P.A. Saccardo, Michelia Commentarium Mycologicum Fungos in Primis Italicos lllustrans 1:342. 1878; Fungi Italici autographice delineati (additis nonnullis cxtra-italicis asterisco notatis). Patavii, table 288. 1878. ESphaeria corticola L. Fuckel, Symbolac Mycologicac, p. 114. 1870. EMctasphacria corricola (L. Fuckel) P.A. Saccardo, Sylloge Fungorum Omnium Hucusque Cognitorum Digessir P.A. Saccardo 2:166. 1883. EGriphosphacria corticola (L. Fuckel) F. v. Hoehnel, Annales Mycologici. Berlin 16:87. 1918. EClathridium corticala (L. Fuckel) R.A. Shoemaker \& E. Mueller, Canadian Joumal of Botany, Otrawa $42: 404$. 
1964. $\equiv$ Discostroma corticola (L. Fuckel) I. Brockmann, Sydowia 28:313. 1975. On cortex of branchlets, on dry stems of Cormus sanguinea L., Lonicera caprifolium L., Prunus baccata Borkh., Prumus domestica L. Prunus spinosa L., Rosa sp., Caprifoliaceac, Rosaceae. Austria. Canada, Czechoslovakia, Germany, Hungary, Italy, Switzerland. = Discostroma fuscella (M.J. Berkeley \& C.E. Broome) S.M. Huhndorf, comb. nov.

L. dryadis E. Rostrup. Botanisk Tidsskrift. Kjobenhavn 25:305. 1903. On decorticated wood stems and fruits of Dryas octopetala L. Rosaceae. Iceland.

=Leptosphaeria dryadophila S.M. Huhndorf, nom. nov.

L. dryadis E. Rostrup. Norske Ascomyceter i Christiania Universitetets Botaniske Museum Christiania [Oslo] (I. Kommission Hos Jacob Dybwad), p. 24. 1904. [Issued in Skrifter Udgivne af Videnskabselskabet i Christiania. Mathematisk-naturvidenskabelig klasse. Christiania (Oslo) No. 274.] Non vidi. On upper surface of dried leaves of Dryas octopetala L., Rosaceae. Norway. (n. v.)

L. eriobotryae H. Sydow, P. Sydow \& E. Butler, Annales Mycologici, Berlin 9:409. 1911. On leaves of Eriobotrya japonica (Thunb.) Lindley, Rosaceae. India. Species incertae sedis.

L. fuscella (M.J. Berkeley \& C.E. Broome) V. Cesati \& G. de Notaris, Commentario della Società Crittogamologica Italiana, Milan 1:236. 1863. ESphaeria (Obtectue) fuscella M.J. Berkeley \& C.E. Broome, Annals and Magazine of Natural History, London, Series 2, 9:325. 1882. On dead lwigs of Rosa sp.. Rosaceae. Great Britain.

$\equiv$ Discostroma fuscella (M.J. Berkeley \& C.E. Broome) S.M. Huhndorf, comb. nov.

L. hazslinszkii P.A. Saccardo, Sylloge Fungorum Omnium Hucusque Cognitorum Digessit P.A. Saccardo 2:28. 1883. [Based on Ditopella sp., published by F.A. Hazslinszky,

Verhandlungen der Zoologisch-Botanischen Gesellschaft in Wien 20:217. 1870.1 On dead branches of Rosa sp.. Rosaceae. Rumania. (n. v.). Type material was not found at B, BP. F, FI, L, NBG, UPS, W, WAG. No reply from IBF, TNP. It is not known whether type material is at PAD because this institution has stopped lending specimens until further notice.

L. (Clypeosphaeria) hendersoniae (J.B. Ellis) M.C. Cooke, Grevillea, London 17:91. 1889. ESphaeria (Obectue) hendersonia J.B. Ellis in M.C. Cooke and J.B. Ellis, Grevillea. London 6:14-15. 1877. EClypeosphueria hendersoniae (J.B. Ellis) P.A. Saccardo,
Sylloge Fungorum Omnium Hucusque Cognitorum Digessit P.A. Saccardo 2:91 1883. On canes of Rubus sp., Rosaceae. United States.

=Kalmusia comiothyrium (L. Fuckel)

S.M. Huhndorf, comb. nov.

L. hollosiana L.E. Wehmeyer, Mycologia, Lancaster, Pennsylvania 55:319. 1963.

$\equiv$ Leptosphaeria maritima L. Hollós. Annales

Historico-Naturales Musei Nationalis Hungarici 5:46. 1907. Non L. maritima Ellis \& Everhart, Non L. maritima Saccardo. On stems of Bieberstcinia emodii Jaub. \& Spach., Potentilla argyrophylla Wallich ex Lehm.,

Potentilla fragarioides L., Triglochin maritima L., Trisctum spicatum (L.) K. Richter, Geraniaceae, Gramineae, Juncaceae, Rosaceae. India. (n. v.). Type material was not found at BP, PAV, PRE.

L. Leiostega (J.B. Ellis) J.B. Ellis, Catalogue of Plants Found in New Jersey. Geological Survey of New Jersey. Final Report of the State Geologist, Trenton 2(1):525. 1889. ESphaeria (Leptosphaeria) leiostega J.B. Ellis, Bulletin of the Torrey Botanical Club (and Torreya), New York 8:91. 1881. On various dead iwigs and limbs of Carya sp.. Rosa sp., Vaccinium sp., Juglandaceae, Rosaceae, Ericaceae. United States (New Jersey).

=Discostroma fuscella (M.J. Berkeley \& C.E. Broome) S.M. Huhndorf, comb. nov.

L. lcjostega (J.B. Ellis) F. Hazslinszky, Matematikai és Természettudományi Közlemenyek Vonatkozólag a Hazai Viszonyokra, Budapest 25(2):148. 1892. ESphacria (Leptosphaeria) leiostega J.B. Ellis, Bulletin of the Torrey Botanical Club (and Torreya), New York 8:91. 1881. झMctasphacria lejostega (J.B. Ellis) P.A. Saccardo, Sylloge Fungorum Omnium Hucusque Cognitorum Digessit P.A. Saccardo 2:164. 1883. On branches of Carya sp., Rosa sp., Vaccinium sp.. Juglandaceac. Rosaceae, Ericaceae. United States (New Jersey).

L. lencoplaca (K.F. Wallroth) E.A. Vainio, Acta Societatis pro Fauna et Flora Fennica, Helsing forsiae 49(2):143-144. 1921. EVerrucaria leucoplaca K.F. Wallroth. Flora Cryptogamica Germaniae 1:299. 1831. EPyrenula leucoplaca (F.G. Wallroth) G.W. Koerber, Systema Lichenum Germaniae, p. 361. 1855. EV crrucaria alha H.A. Schrader var. leucoplaca (F.G. Wallroth) L.E. Schaerer in Enumeratio Critica Lichenum Europaeorum, Quos Ex Nova Methodo Digerit, p. 219. 1850. EEopyremules lewooplaca (K.F. Wallroth) R.C. Harris, The Michigan Botanist. Ann Arhor 12:19. 1973. 
On bark of Acer sp., Alnus sp., Carya sp.. Corvlus sp. Fraxinus sp.. Juglans sp.. Populus sp., Quercus sp., Salix sp., Sorbus sp., Tilia sp., Ulmus sp., Aceraceae, Juglandaceae. Betulaceae, Oliaceae,

Salicaceae, Fagaceae, Rosaceae, Tiliaceae, Ulmaceae. Finland. (n. v.). No reply from STR.

L. Incilla P.A. Saccardo, Nuovo Giornale Botanico Italiano e Bolletino della Società Botanica Italiana, Firenze 7:310-311. 1875. Indiscriminately on wilted leaves of Pyrus communis L., Rosaceae. Italy.

EPlacosphaeria hucilla (P.A. Saccardo) S.M. Huhndorf, comb. nov.

L. mandshurica M. Miura, Flora of Manchuria and East Mongolia, Part III, Cryptogams, Fungi (Contributions of the Southern Manchuria Railway Company 27): 175. 1928. On leaves of Pyrus malus L. [as Malus domestica Borkh.]. Rosaceae. China. (n. v.). Type material was not found at TI, TKB. No reply from TFM, TOFO, TNS.

L. minima (J.E. Duby) ex P.A. Saccardo, Michelia Commentarium Mycologicum Fungos in Primis ltalicos lllustrans 2:320. 1881. $\equiv$ Sphaeria minima J.E. Duby in C. Roumeguère, Fungi Selecti Gallici Exsiccati. Century 7, No. 694. Anno 1880. Nom. nud. EMycotodea minima (J.E. Duby ex P.A. Saccardo) W. Kirschstein in O.C. Schmidt, Kryptogamenflora der Mark Brandenburg und Angrenzender Gebiete herausgegeben von den Botanishen Verein der Provinz Brandenburg, Leipzig 7(3):432. 1938. On leaves of Porentilla argentea L., Rosaceae. France. Species incertae sedis.

L. miyakeana P.A. Saccardo, Sylloge Fungorum Onmium Hucusque Cognitorum Digessit P.A. Saccardo 24:999. 1928. EPhaeosphaeria crioborrye 1. Miyake, Botanical Magazine, Tokyo 27:41-42. 1913. ETrematosphaerella crioboryac (1. Miyake) F.L. Tai, Sylloge Fungorum Sinicorum, p. 330. 1979. On leaves of Eriohorya japonica (Thunb.) Lindley, Rosaceac. China. (n. v.). Type material was not found at Tl, TKB. No reply from TFM, TOFO, TNS. It is not known whether type material is at PAD since this institution has stopped lending specimens until further notice.

L. mumı K. Hara, Byôchu-gai Zasschi (Journal of Plant Protection), Tokyo 5:884. 1918. |As munc in original publication.] On dead hrancli of Prumus mume Sieb. \& Zucc., Rosaceac. Japan. (n. v.). Type material was not lound at Tl, TK13. No reply from TFM, TOFO. TNS.
L. nashi (K. Hara) P.A. Saccardo in A. Trotter, Sylloge Fungorum Omnium Hucusque Cognitorum Digessit P.A. Saccardo 24:999. 1928. ELeplosphaerella nashi $\mathrm{K}$. Hara. Kajyu-byogai-ron Nihon-kankitsu-Kai, Schiznoka [Fruit Tree Diseases]. pp. 142-145 1916. 三Phaeospora nashi (K. Hara) K. Hara. Jitsuyo-Sakumotsu-Byorigaku [Manual of Plant Pathology], p. 270. 1925. On leaves of Pyrus sinensis Hort., Rosaceae. Japan. (n. v.). Type material was not found at Tl, TKB. No reply from TFM, TOFO. TNS.

L. (Clypeosphaeria) notarisii M.C. Cooke, Grevillea, London 17:9] . 1889. ESphaeria clypeiformis G. de Notaris, Memorie Della Accademia delle Scienze di Torino, Series 2, No. 7, p. 113. 1853: Micromycetes Italici Novi vel Minus Cogniti 7. p. 113. 1845. Non Sphaeria clypeiformis L.V. de Lacroix in G.L.

Rabenhorst. $\equiv$ Clypeosphaeria notarisii L.

Fuckel, Symbolae Mycologicae, p. 117. 1870. On barky runners of Rubus fruticosus L., Rosaceae. Italy. $=$ Clypeosphaeria mamillana $($ E.M. Fries: E.M. Fries) J.B.E. Lambotte.

L. ohesula P.A. Saccardo in V. Mouton, Bulletin. Société R. de Botanique de Belgique. Bruxelles 26:176. 1887. On stems of Acer psendoplatanus L., Angelica sp., Spiraea ulmaria L. (=Filipendula ulmaria Maxim.). Aceraceae, Umbelliferae, Rosaceae. Belgium. (n. v.). Type material was not found at DUKE. No reply from AUT. CGE. LD. It is not known whether type material is at PAD because this institution has stopped lending specimens until further notice.

L. oligotheca F. Petrak \& H. Sydow, Annales Mycologici, Berlin 22:359. 1924. [Described from the type material of Laestadia potentillae E. Rostrup, Botanisk Tidsskrift, Kjobenhavn 25:300. 1903.] On leaves of Potentilla maculata Pour. (=Potentilla aurea L.). Rosaceae. Denmark, Iceland. =Leptosphaerulina pulchra (H.G. Winter) M.E. Barr.

L. (Clypeosphaeria) asculanda (C.G.T. Preuss) M.C. Cooke. Grevillea. London 17:91. 1889. Esphacria osculanda G.T. Preuss, Linnaea. Institut botanique de l'Université de Genève 26:713. 1853. EClypeosphaeria osculanda (G.T. Preuss) P.A. Saccardo, Sylloge Fungorum Omnium Hucusque Cognitorum Digessit P.A. Saccardo 2:91. 1883. On hranches of Rubus sp.. Rosaceae. Germany. (n. v.). Type material was not found at B.

L. oryspora J. Feltgen, Vorstudien zu einer PilzFlora des Grossherzogthums, Luxemburg 1(2):165-166. 1901. On dry stems of Rubus idce'ts L.. Rosaceae. Luxemburg. (n. v.). 
Type material is probably at LUX but was not obtained because the collections are undergoing reorganization.

L. pachytheca P.A. Saccardo, Nuovo Giomale Botanico ltaliano e Bolletino della Società Botanica ltaliana, Firenze, New Series 22:39. 1915. Nom. illeg. Art. 64.1. On dead branches of Amygdalus communis L. [=Prunus dulcis (Mill.) D.A. Webb], Rosaceae. Yugoslavia. (n. v.). It is not known whether type material is at PAD because this institution has stopped lending specimens until further notice.

L. (Lepiosphaerella) pomona P.A. Saccardo, Nuovo Giomale Botanico ltaliano e Bolletino della Società Botanica Italiana, Firenze 8:176. 1876. On upper surface of leaves of Pyrus malus L. (=Malus domestica Borkh.).

Rosaceae. Italy.

EPhaeosphaeria pomona (P.A. Saccardo)

S.M. Huhndorf, comb. nov.

L. pomona P.A. Saccardo forma transilvanica A. Negru et 1. Ditzu, Notulae Systematicae e Sectione Cryptogamica Instituti Botanici Nomine V.L. Komarov Academicae Scientiarum U.R.S.S., Petropolis 16:152-153. 1963. On fruits of Crataegus monogyna Jacq., Rosaceae. Rumania. (n. v.). Type material was not found at BUCM. No reply from BUC, BUCA, BUCF, CL.

L. poterii G. Passerini, Atti dell' Accademia Nazionale dei Lincei. Memoire, Rome, Series 4, 6:459. (1889) 1890. On wilted stems of Poterium sanguisorba L., Rosaceae. Italy. (n. v.). Type material was not found at PARMA, PISA, PAD.

L. praetermissa (P.A. Karsten) P.A. Saccardo, Sylloge Fungorum Omnium Hucusque Cognitorum Digessit P.A. Saccardo 2:26. 1883. ESphaeria praetermissa P.A. Karsten. Fungi Fenniae Exsiccati, Century 9, No. 852. Anno 1869. On dried canes of Ruhus idaeus L., Rubus odoratus L., Rosaceae. Finland. L. prumi N.N. Woronichin, Vestnik Tiflisskogo Botanicheskogo Sada, Tiflis (Moniteur du Jardin Botanique de Tiflis) 28:17-18. 1913. On living leaves of Prumus domestica L.. Rosaceac. U.S.S.R. (Caucasus). (n. v.). Type material was not found at LE, LEP, TBI. No reply from TGM.

L. pulchra (H.G. Winter) P.A. Saccardo, Sylloge Fungorum Omnium Hucusque Cognitorum Digessit P.A. Saccardo 2:53-54. 1883.

ESphaerella pulchra H.G. Winter, Hedwigia. Dresden 11:145-146.1872. EMycodotea pulchra (H.G. Winter) W. Kirschstein, Annales Mycologici, Berlin 34:201. 1936; Kryptogamenflora de Mark Brandenburg und Angrenzender Gebiete herausgegeben von den
Botanischen Verein der Provinz Brandenburg. Leipzig 7(3):433. 1938. On dry stems and leaves of Potemilla caulescens L., Rosaceae. Austria. Type material was not found at B. CORD, IBF, JE, LZ. WRSL. No reply from FI, IB, TO, WAG.

ELeptosphaerulina pulchra (H.G. Winter)

M.E. Barr, Contributions de l'Institut

Botanique de L'Universitć de Montréal 73:7. 1959.

L. puntemansii A. Maublanc, Bulletin de la Société Mycologique de France, Paris 21:88-89.

1905. On leaves of Eriobonrya japonica (Thunb.) Lindley, Rosaceae. Brazil. (n. v.). Type material was not found at IBI, PC, RSAPOM. SP. No reply from RBR.

L. rimicola (G.H. Otth) P.A. Saccardo, Hedwigia, Dresden 35:XX1X. 1896; Sylloge Fungorum Omnium Hucusque Cognitorum Digessit P.A. Saccardo 11:XX1X. 1896. ECladosphaeria rimicola G.H. Otth. Mitteilungen der Naturforschenden Gesellschaft in Bern 1870:106. 1871. Nom inval. Art. 43.1. [The genus Cladosphaeria was validated in 1894.] On fallen branches of Prumus arium L.,

Rosaceae. Switzerland. =Melanomma pulvis-pyrius (C.H. Persoon:E.M. Fries) L. Fuckel.

L. rostrupii P.A. Saccardo \& D. Saccardo in P.A. Saccardo, Sylloge Fungorum Omnium Hucusque Cognitorum Digessit P.A. Saccardo 17:721 . 1905. ELeptasphaeria dryadis $\mathrm{E}$. Rostrup. Non Rostrup 1903. On upper surface of dried leaves of Dryas octopetala L., Rosaceac. Norway. (n. v.). It is not known whether type material is at PAD since this institution has stopped lending specimens until further notice.

L. rustica P.A. Karsten, Fungi Fenniae Exsiccati, Century 10. No. 964. Anno 1870. 三Metasphaeria rustica (P.A. Karsten) P.A. Saccardo, Sylloge Fungorum Omnium Hucusque Cognitorum Digessit P.A. Saccardo $2: 157$. 1883. On stems of Spiraea ulmaria L. (=Filipendula ulmaria Maxim.), Rosaccae. Finland.

=Leprosphaeria dolishlum (C.H. Persoon:E.M. Frics) V. Cesati \& G. de Notaris.

L. sac'ardiana J.H. Fahre, Annales des Sciences Naturelles, Paris, Botanique, Series 6, 9:89. 1878. ERequienella saccardiana (J.H. Fabre) J.H. Fabre, Annales des Sciences Naturelles, Paris, Botanique, Series 6, 15:56. 1883. On dried stems of Cratacgus oryoumba L..

Rosaceac. France. (n. v.). Type material was not found at PC. No reply from L'HARMAS.

L. sanguisorhae P'A. Karsten in A.N. Berlese, Icones Fungorum Omnium Hucusque Cognitorum ad usum Sylloges Saccardianac 
Adcommodatae 1:78. 1892. On brancires of Sanguisorha officinalis L., Rosaceac. Gemany: (n. v.). Type material was not found at H. UPS.

L. sanguisorhate P.A. Karsten. Enumeratio

Fungorum et Myxomycetum in Lapponia Orientali Aestate 1861 Lectorum. p. 214. 1886: Notiser Sallskapets l'ro Fauna et Flora Fordhandlingar $8: 214$. IS66. [As Sphaeria (Leplosphacria) samgirsorbare.] On dead stems of Sanguisorlba polygama F. Nyl..

Rosaceac. U.S.S.R. (n. V.).

L. sepincold (E.M. Fries:E.M. Fries) H.G. Winter.

Dr. L. Rabenhorst 's Kryptogaman-Flora von Deutschland, Oesterreich und der Schweiz. Second edition, 1(2):473. 1885. SSphaeria scpincole E.M. Fries, Ohservationes Mycologicae. Seu Descriptiones tim Novarum, quam Notahilium Fungorum Exhibiae a C.H. Persoon, Lipsiac 1:181. 1815: Systema Mycologicum Sistens Fungorum 2:498. 1823. [As sacpincola.] 三Pringshermia sepincola (E.M. Fries:E.M. Fries) F. v. Hoehnel, Annales Mycologici. Berlin 18:97. 1920. EMelasphaeria sepincola (E.M. Fries:E.M. Fries) P.A. Saccardo. Sylloge Fungorum Omnium Hucusque Cognitorum Digessit P.A. Saccardo 2:164. 1883. [As Fr? Fuckel.] ESphacrulina sepincolu (E.M. Fries:E.M. Fries) K.Starbäck, Botaniska Notiser, Lund 1890:117. 1890: Botanisches Zentralblatı, Jena \& Dresden \$6:261. 1891. EPleasphaerulina sepincola (E.M. Fries:E.M. Fries) H. Rehm in F. v. Hoehnel, Annales Mycologici, Berlin 18:96 1920. ESclerodorhis sepincola (E.M.

Fries:E.M. Fries) F. Petrak, Annales Mycologici, Berlin 19:41. 1921. On dry stems of Rosa sp.. Rubus sp.. Rosaceae. Sweden.

三Sacrahecium sepincala (E.M. Fries:E.M.

Fries) E.M. Fries. Summa Vegetabilium Scandinaviae, Seu Enumeratio. Systematica et Critica, Plantanum tum Cotyledonearum. Quam Nemearum Inter Mare Occidentale Et Album. Inter Eidoram et Nordkop. Hactenus Lectorum, una Cum Singulae Distributione Geographica. p. 398. 1849.

L. sieversiae (F.E. Clements) F. Petrak, Sydowia. Annales Mycologici, Horn, N.Ö. 6(1-4):6. 1952. 三Massaria sieversiae F.E. Clements. Cryprogamae Formationum Coloradensium. Century 111. No. 234. Anso 1906. Nom. nud. Art. 36.1. (Combination is not valid because the basionym is an invalidly published species.] On standing, dead stems of Sieversia turbinala (Rydb.) Greene, Rosaceae. U.S.A.

=Diadema sieversiae (C.H. Peck) S.M.

Huhndorf, comb. nov.
L. sorbi A. Jaczew'ski, Annales Mycologici, Berlin 1:30. 1903. On leaves of Sorbus aucuparia L., Rosaceac. U.S.S.R.

Species incertac sedis.

L. spiracac P.A. Karsten, Hedwigia, Dresden 27:260. 1888. On dry fallen branches of Spiraca sarbifolia L. (=Sorharios sorhifolia A. Br.), Rosaceac. Finland. (n. v.). Type material was not lound at II, UPS.

L. subcufunea (M.C. Cooke \& J.B. Ellis) J.B. Ellis in N.L. Britton. Catalogue of Plants Found in New Jersey. Geological Survey of New Jersey. Final Report of the State Geologist. Trenton 2(1):525. 1889. ESphacria (subrectae) subcutanca M.C. Cooke \& J.B. Ellis, Grevillea. London 7:41. 1878.

EMerasphaeria subcuranea (M.C. Cooke \& J.B. Eilis) P.A. Saccardo, Sylloge Fungorum Omnium Hucusque Cognitorum Digessit P.A. Saccardo 2:167. 1883. On decorticated limbs of Pyrus communis L., Rosaceae. United States. (New Jersey).

三Lopliostoma subcutanea (M.C. Cooke \& J.B. Ellis) S.M. Huhndorf, comb. nov.

L. superficialis F.A. Hazslinszky, Matematikai és Természettudományi Közlemenyek Vonatkozólag a Hazai Viszonyokra. Budapesi 25(2):146. 1892. On unknown substrate of Potenilla argentea L., Rosaceac. Hungary. (n. v.). Type material was not found at B, BP, F. FI, L, NBG, UPS, W, WAG. No reply from IBF. TNP.

L. ternafa F. Hazslinszky. Matematikai és Természettudományi Közlemenyek Vonatkozólag a Hazai Viszonyokra. Budapesı 25(2):150. 1892. On branches of Pyrus malus L. (=Malus domestica Borkh.), Rosaceae. Hungary. (n. v.). Type material was not found at B, BP, F, FI, L, NBG, UPS, W. WAG. No reply from $1 B F$, TNP.

L. Ihomasiana P.A. Saccardo \& C. Roumeguère, Revue Mycologique. Toulouse 5:236. 1883. On dead runners of Rubus sp., Rosaceae. France. It is not known whether type material is at PAD because this institution has stopped lending specimens until further notice. $\equiv$ Phacosphacria thomasiana (P.A. Saccardo \& C. Roumeguère) S.M. Huhndorf, comb. nov.

L. umbrosa G. Niessl in G.L. Rabenhorst, Fungi Europaei Exsiccati. Klotschii Herbarii vivi Mycologici Continuatio, Edition 3 (Edita Nova), Series 2. Century 20, No. 1934. Anno 1875; Jusi's Botanisch Jahresberichte, Berlin 3:262. 1887. 三Massaria umbrosa (G. Niessl) H. Rehm in P.A. Saccardo, Sylloge Fungorum Omnium Hucusque Cognitorum Digessit P.A. Saccardo 9:761. 1891. On unknown substrate of Actaea spicata L., Astrantia majar L., 
Gentiana asclepiadea L., Solamum dulcamara

L., Spiraea aruncus L. (=Aruncus dioicus

Fern.). Ranunculaceae, Umbelliferae,

Gentianaceae, Solanaceae, Rosaceae. Austria.

L. vagabunda P.A. Saccardo, Nuovo Giomale

Botanico Italiano e Bolletino della Società

Botanica ltaliana, Firenze 7:318. 1875.

三Sphaeria fuscella P.A. Saccardo, Atti dell”

Accademia Scientifica Veneto-Trentino-

Istriana, Padova 2(]):145. 1873. [As

Sphaeria fuscella M.J. Berkeley \& C.E.

Broome. Non Leptosphaeria fuscella (M.J.

Berkeley \& C.E. Broome) V. Cesati \& G. de

Notaris.] On branches of Abies excelsa

(Lam.) Poiret, Acer campestre L., Almus

glutinosa (L.) Gaertner. Ampelopsis

heteroplylla (Thunb.) Sieb. \& Zucc.,

Clematis vitalba L., Cornus sanguinea L.,

Corylus avellana L., Dulcamara sp..

Hypericum calycinum L.. Kerria japonica (L.)

DC., Quercus pedunculata Ehrh., Salix

purpurea L., Pinaceae, Aceraceae.

Betulaceae, Vitaceae, Ranunculaceae,

Cornaceae, Solanaceae, Guttiferae, Rosaceae,

Fagaceae, Salicaceae. Italy. (n. v.). It is not

known whether type material is at PAD

because this institution has stopped lending

specimens until further notice.

L. vagabunda P.A. Saccardo var divergens P.A.

Saccardo. Fungi Italici autographice delineati

(additis nonnullis extra-italicis asterisco notatis), Patavii, No. 518. 1879; Sylloge

Fungorum Omnium Hucusque Cognitorum

Digessit P.A. Saccardo 2:31. 1883. On

branches of Kerria sp., Rosaceae. Italy. (n.

v.). It is not known whether type material is at PAD because this institution has stopped lending specimens until further notice.

L. vagabunda P.A. Saccardo var, sarmenti P.A.

Saccardo, Fungi ltalici autographice delineati (additis nonnullis extra-italicis asterisco notatis), Patavii, No. 428. 1879; Sylloge Fungorum Omnium Hucusque Congitorum Digessit P.A. Saccardo 2:31. 1883. On runners of Rubus sp., Rosaceae. Italy. (n. v.). It is not known whether type material is at PAD because this institution has stopped lending specimens until further notice. 


\section{Litcrature Cited}

ArX, J.A. voN, and E. MüLLER. 1975. A re-evaluation of the bitunicate Ascomycetes with keys to families and genera. Studies in Mycology 9:1-159.

BARr, M.E. 1959. Northern Pyrenomycetes I. Canadian eastern arctic. Contributions de l'institut botanique de l'université de Montréal 73:1-101.

Barr, M.E. 1967. Northern Pyrenomycetes III. Western species. Canadian Journal of Botany 45:1041-1046.

BARr, M.E. 1972. Preliminary studies on the Dothideales in temperate North America. Contributions from the University of Michigan herbarium 9:523-638.

\section{BARR, M.E. 1982. Lepiosplaceria sepalorum.} Mycotaxon 15:345-348.

BARR, M.E. 1983. The Ascomycete connection. Mycologia 75:1-13.

Barr, M.E. 1987a. Prodromus to class Loculoasconycetes. Hamilton 1. Newell, Amherst, Massachusetts. $168 \mathrm{pp}$.

BARR, M.E. 1987b. New taxa and combinations in the Loculoascomycetes. Mycotaxon 29:501-505.

BARR, M.E. 1989. Clypeosphaeria and the Clypeosphaeriaceac. Systema Ascomycetum 8(1):]-8.

Berkeley, J.M., and C.E. BroOMi. 1852. Notices of British fungi. Amnals and Magazine of Natural History II 9:317-329.

BERIESE, A.N. 1890. lcones Fungorum. vol. I. pp. 44-45. Abellini.

BROCKMAV, I. 1975. Untersuchungen über die Gattung Discostroma Clements (Ascomycetes). Sydowial 28:275-338.

Cesali, V., and G. de Notaris. 1863. Schema di Classilicazione degli Sleriace italici aschigeri. Commenfario della Societa Crittogamologia italiana. Nilan 1:177-240.
Chesters, C.G.C. 1938. Studies on British Pyrenomycetes 11. A comparative study of Melanomma pulvis-pyrius (Pers.) Fuckel. Melanomma fuscidulum Sacc. and Thyridaria rubronotata (B. \& Br.) Sacc. Transactions of the British Mycological Society 22:116-150.

COOKE, M.C. 1871. Handbook of British fungi. Macmillan, London and New York. 981 pp.

Crane, J.L., and C.A. ShEarer. 199l. A nomenclator of Leptosphaeria V. Cesati and G. de Notaris (Mycota-Ascomycotina-Loculoascomycetes). Illinois Natural History Survey Bulletin 34(3):195355 .

DEnNIS, R.W.G. 1978. British Ascomycetes. J. Cramer, Vaduz. 585 pp.

ERIKSSON, O. 1981. The families of bitunicate ascomycetes. Opera Botanica 60:1-209.

ERIKSSON, O., and D.L. HAWKSWORTH. 1985. Outline of the Ascomycetes-1985. Systema Ascomycetum $4: 1-79$.

ERIKsson, O., and D.L. Hawksworth. 1986. Outline of the Ascomycetes-1986. Systema Ascomycetum $5(2): 185-324$.

Eriksson, O., and D.L. Hawksworth. 1990. Outline of the Ascomycetes-1989. Systema Ascomicetum $8(2): 119-318$.

Froidevaux, L. 1973(1972). Contribution à l'étude des Dothioracées (Ascomycètes). Nova Hedwigia 23:679-734.

Fuckel, L. 1870. Symbolae Mycologicale. Jahrbucher des Nassauischen Vereins fur Naturhunde 23-24:1-459.

Hedjaroude, G.A. 1968 (1969). Études taxonomiques sur les Phacosphaeria Mlyake et leurs fomes voisines (Ascomycètes). Sydowia 22:57-107.

Hol.d. L. 1957. Études taionomiques sur les P'léosporacées. Symbolae Botanicae Upsaliemses $14(3): 1-188$. 
Holm, L. 1975. Taxonomic notes on Pyrenomycetes. Taxon 24(4):475-488.

Holm, L. 1979. Microfungi on Dryas. Botaniska Noliser 132:77-92.

Holm, L., and K. Holm. 1988. Studies in the Lophiostomataceae with emphasis on the Swedish species. Symbolae Botanic ae Upsalienses 28(2): 1-50.

Holmgren, P.K., W. Keuken, and E.K. Schofield. 1981. Index herbariorum. Part 1. The herbaria of the world, 7 th ed. Oosthoek, Scheltema \& Holkema, Utsecht.

HuHNDORF, S.M. 1991. A method for sectioning ascomycete herbarium specimens for light microscopy. Mycologia 83:520-524.

Karsten, P.A. 1873. Pyronomycetes. Mycologia Fennica 2:105.

KORF, R.P. 1958. Japanese discomycete notes 1-Viii. Science Reports of the Yokohama National University, sect. 2. 7:7-35.

Leuchtmann, A. 1984. Über Phaeosphaeria Miyake und andere bitunicate Ascomyceten mit mehrfach querseptierten Ascosporen. Sydowia 37:75-194.

LutTrell, E.S. 1973. Loculoascomycetes. Pages 135-219 in G.C. Ainsworth, F.K. Sparrow, and A.S. Sussman (eds.) The fungi, an advanced treatise. Vol. IVA. A taxonomic review with keys: Ascomycetes and Fungi Imperfecti. Academic Press, New York and London.

Müller, E. 1950. Die schweizerischen Arten der Gattung Leptosphaeria und ihrer Verwandten. Sydowia 4:185-319.

Munk, A. 1957. Danish Pyrenomycetes. Dansk Botasisk Arkiv 17(1):1-491.

NiESSL, G.V. (1871) 1872. Beitrage zur Kenntniss der Pilze. Verhandlungen des naturforschenden Vereines in Brün 10:153-215.

Peck, C.H. 1913. Report of the State Botanist 1912. New York State Museum Bulletin 167:1-137.

Petrak, F., and H. Sydow. 1924. Kritischsystematische Originaluntersuchungen über Pyrenomyzeten, Sphaeropsideen und Melanconicen II. Annales Mycologici 22:359.

Pfister, D.H. 1985. A bibliographic account of exsiccatae containing fungi. Mycotaxon 23:1-139.

SACCARDO, P.A. 1875. Fungi Veneti novi vel critici. Series II. Nuovo Giomale Botanico Italiano 7:310311 .
Saccardo, P.A. 1876. Fungi Veneti novi vel critici. Series V. Nuovo Giomale Botanico ltaliano 8:176.

Saccaroo, P.A. 1878. Fungi Veneti novi vel critici. Series 11I. (ex Hedwigia, XIV (1875)) Michelia $1: 446-452$.

Shearer, C.A., J.L. Crane. and K.R. Chanora REDDY. 1990. Studies in Leptosphaeria.

Lectotypification of Sphaeria doliohum. Mycologia $82: 496-500$.

SHOEMAKER, R.A. 1976. Canadian and some extralimital Ophiobohus species. Canadian Journal of Botany 54:2365-2404.

Shoemaker, R.A. 1984a. Canadian and some exiralimital Leptosphaeria species. Canadian Jouma] of Botany 62:2688-2729.

ShOEMAKER, R.A. 1984b. Canadian and some extralimital Nodulosphaeria and Entodesmium species. Canadian Joumal of Botany 62:2730-2753.

Shoemaker, R.A., and C.E. BabCock. 1985. Canadian and some extralimital Paraphaeosphacria species. Canadian Journal of Botany 63 : 1284-1291.

Shoemaker, R.A., and C.E. BabCock. 1987. Wettsteinina. Canadian Journal of Botany 65:373-405.

Shoemaker, R.A., and C.E. BABCoCk. I989a. Diadema. Canadian Joumal of Botany 67:13491355.

Shoemaker, R.A., and C.E. Babcock. 1989 b. Phaeosphaeria. Canadian Joumal of Botany $67: 1500-1599$.

Shoemaker, R.A., and O. Eriksson. 1967.

Paraphaeosphaeria michotii. Canadian Joumal of Botany 45:1605-1608.

SivANESAN. A. 1984. The bitunicate Ascomycetes and their anamorphs. J. Cramer, Vaduz. 701 pp.

WeHmeyer, L.E. 1933. The genus Diaporthe Nitschke and its segregates. University of Michigan studies. Scientific series 9:1-349.

WeHMEYER, L.E. 1957. The genera Sac'othecium, Pringsheimia, Pleosphaenulina and Pseudoplea. Mycologia 49:83-94.

WeHmeyer, L.E. 1963. Himalayan Ascomycetes. Mycologia 55:319.

ZELLER, S.M. 1927. Contributions to our knowledge of Orcgon fungi-JI, Mycological notes for 1925. Mycologia 19:130-143. 


\section{Index to Taxa}

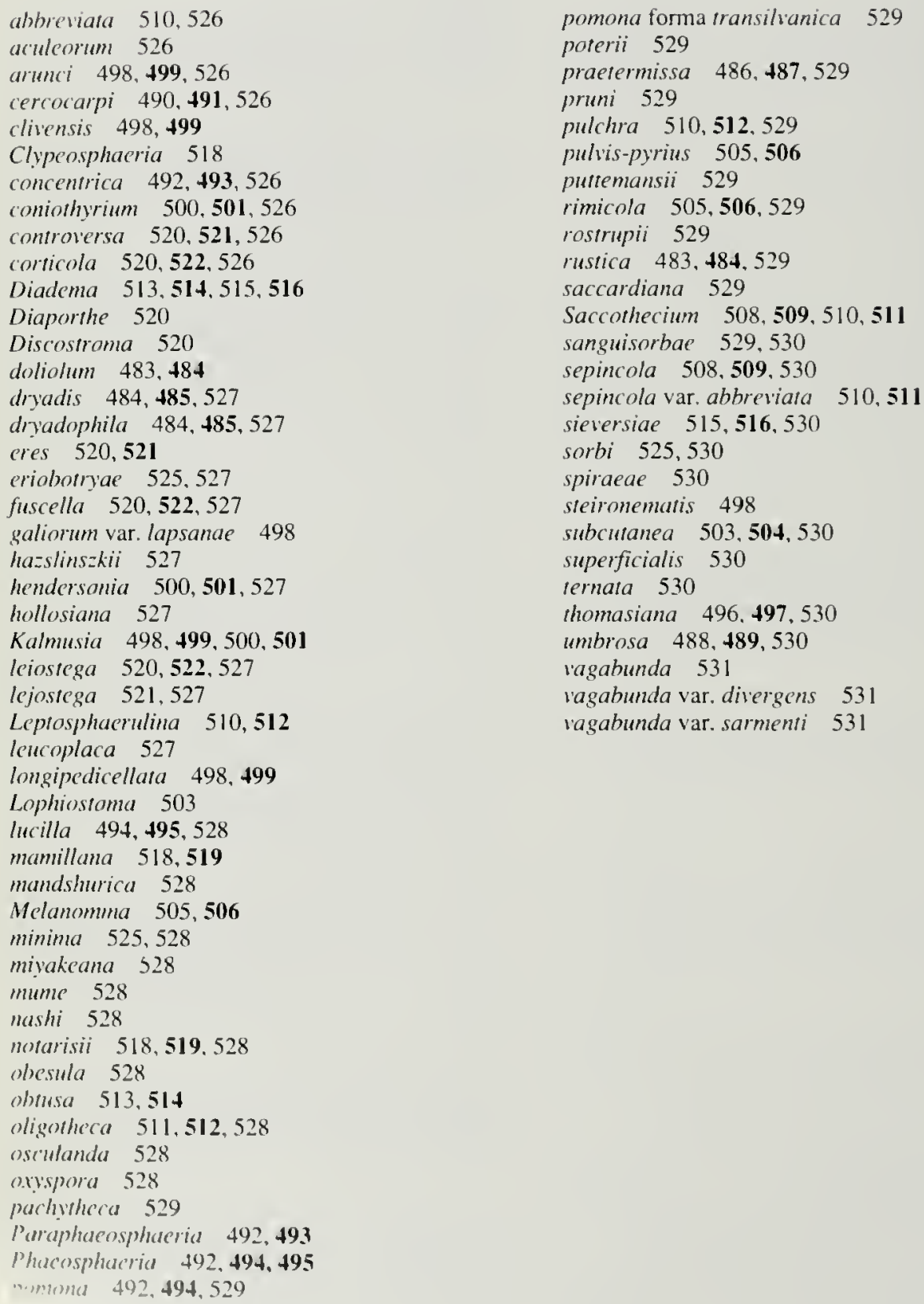




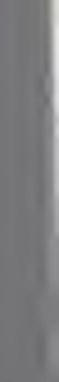


Illinois Natural History Survey

Natural Resources Building

607 East Peabody Drive

Champaign, Illinois 61820

$217-333-6880$

A Division of the Illinois Department of Energy and Natural Resources 